\title{
PETRÓLEO NA MARGEM CONTINENTAL BRASILEIRA: GEOLOGIA, EXPLORAÇÃO, RESULTADOS E PERSPECTIVAS
}

\author{
E. J. Milani, J. A. S. L. Brandão, P. V. Zalán \& L. A. P. Gamboa \\ Received September 27, 2001 / Accepted December 05, 2001
}

\begin{abstract}
O conceito de sistema petrolífero agrupa os diversos elementos que controlam a existência de jazidas de petróleo numa bacia sedimentar. Tal conceito, visualizado numa escala global, parece justificar de maneira adequada as diversas províncias petrolíferas conhecidas. A evolução tectono-sedimentar meso-cenozóica da margem continental brasileira propiciou o desenvolvimento desses elementos-chave, cuja presença é requisito fundamental a que uma determinada região seja atrativa para a prospecção petrolífera. Merece destaque nesse particular o segmento de águas profundas da Bacia de Campos, que, na visão contemporânea, representa a porção mais bem aquinhoada em termos de volumes descobertos de toda a margem brasileira. Em termos históricos, a exploração de petróleo no Brasil inclui três grandes fases: o período pré-Petrobras, basicamente de atividades pioneiras de reconhecimento; a etapa de exclusividade da Petrobras, onde se vislumbram quatro etapas - 1954/1968: Fase Terrestre, 1969/1974: Fase Marítima/Plataforma Rasa, 1975/ 1984: Fase Marítima/Plataforma Rasa/Bacia de Campos, e 1985/1997: Fase Marítima/ Bacia de Campos/Águas Profundas, cada uma delas com características particulares e responsável por sucessivos incrementos na reserva petrolífera do País, que alcança hoje cerca de 16 bilhões de barris de óleo-equivalente; e a fase atual, sob a vigência da Nova Lei do Petróleo, caracterizada por intensa atividade em que várias companhias nacionais e estrangeiras atuam tanto em áreas anteriormente trabalhadas como em desafiadoras novas fronteiras.
\end{abstract}

Palavras-chave: Exploração de Petróleo; Províncias Petrolíferas; Reserva petrolífera do Brasil; Margem continental.

PETROLEUM IN THE BRAZILIAN CONTINENTAL MARGIN: GEOLOGY, EXPLORATION, RESULTS AND PERSPECTIVES - The set of geological elements that control the petroleum existence and distribution in the sedimentary basins are integrated under the concept of petroleum systems. Such a concept seems to adequately justify the known petroleum provinces worldwide. The Mesozoic-Cenozoic tectono-sedimentary evolution of the Brazilian margin provided the key elements for petroleum existence. In the present day view, the deep water domain of the Campos Basin appears as the area where petroleum systems worked in a very favourable manner, being the region that presently holds most of Brazilian oil and gas reserves. The history of petroleum exploration in Brazil includes three major phases: the pre-Petrobras phase, characterized by pioneer recognition activities; the Petrobras period, when the Company worked under the monopoly regime, including the following sub-phases - 1954/1968: exploration in land, 1969/1974: shallow water activities; 1975/1984: shallow water in Campos Basin; and 1985/1997: deep water exploration; each one of these sub-phases had very peculiar characteristics, and the Brazilian petroleum reserves increased progressively during the entire phase, reaching today the amount of 16 billion barrels of oil-equivalent. Today, the Country is living under 
the New Regulation of the Petroleum Sector; new players came into the game, re-exploring older provinces and reaching brand new, challenging frontiers.

Key words: Petroleum exploration, Petroleum Provinces; Brazilian petroleum reserves; Continental margin.

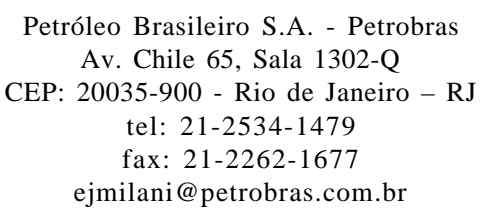

\section{O CONCEITO DE SISTEMA PETROLÍFERO}

A indústria petrolífera foi gradualmente percebendo, ao longo de décadas de exploração, que para se encontrar jazidas de hidrocarbonetos de volume significativo era imperioso que um determinado número de requisitos geológicos ocorressem simultaneamente nas bacias sedimentares. $\mathrm{O}$ estudo destas características de maneira integrada e a simulação preliminar das condições ótimas para sua existência concomitante, com o objetivo de permitir a diminuição do risco exploratório envolvido nas perfurações de poços, um item de elevado custo, foram consolidados em um único conceito: o de sistema petrolífero (Magoon \& Dow, 1994).

Um sistema petrolífero ativo compreende a existência e o funcionamento síncronos de quatro elementos (rochas geradoras maturas, rochasreservatório, rochas selantes e trapas) e dois fenômenos geológicos dependentes do tempo (migração e sincronismo), que serão descritos a seguir.

\section{Rochas geradoras}

O elemento mais importante e fundamental para a ocorrência de petróleo em quantidades significativas em uma bacia sedimentar, em algum tempo geológico passado ou presente, é a existência de grandes volumes de matéria orgânica de qualidade adequada acumulada quando da deposição de certas rochas sedimentares que são denominadas de geradoras. São estas rochas que, submetidas a adequadas temperaturas e pressões, geraram o petróleo em subsuperfície. Se este elemento faltar em uma bacia, a Natureza não terá meios de substituí-la, ao contrário dos outros cinco elementos constituintes do sistema petrolífero, que mesmo estando ausentes, podem ser de alguma forma compensados por condições de exceções geológicas ou por algumas coincidências adequadas.

Rochas geradoras são normalmente constituídas de material detrítico de granulometria muito fina (fração argila), tais como folhelhos ou calcilutitos, representantes de antigos ambientes sedimentares de baixa energia e que experimentaram, por motivos diversos, explosões de vida microscópica. Os remanescentes orgânicos autóctones (material planctônico) ou alóctones (material vegetal terrestre carreado para dentro do ambiente) são incorporados às lamas sob a forma de matéria orgânica diluída. A princípio, quanto maior a quantidade de matéria orgânica, mais capacidade terá a rocha para gerar grandes quantidades de petróleo. Entretanto, a incorporação desta matéria orgânica na rocha deve vir acompanhada da preservação de seu conteúdo original, rico em compostos de $\mathrm{C}$ e $\mathrm{H}$. Para isto, o ambiente deve estar livre de oxigênio, elemento altamente oxidante e destruidor da riqueza em $\mathrm{C} \mathrm{e} \mathrm{H}$ das partículas orgânicas originais. Em suma, ambientes anóxicos favorecem a preservação da matéria orgânica e, conseqüentemente, a manutenção da riqueza original de rochas geradoras.

De uma maneira geral, rochas sedimentares comuns apresentam teores de Carbono Orgânico Total (COT, teor em peso) inferior a $1 \%$. Para uma rocha ser considerada como geradora seus teores devem ser superiores a este limite de $1 \%$ e, muito comumente, situados na faixa de $2 \%-8 \%$, não sendo incomuns valores de até $14 \%$; mais raramente, até $24 \%$. O tipo de petróleo gerado depende fundamentalmente do tipo de matéria orgânica preservada na rocha geradora. Matérias orgânicas derivadas de vegetais superiores 
tendem a gerar gás, enquanto o material derivado de zooplancton e fitoplancton, marinho ou lacustre tende a gerar óleo. O estágio de maturação térmica de uma rocha geradora, ou seja, a temperatura na qual ela está gerando petróleo, também influenciará no tipo de petróleo gerado. Em condições normais, uma rocha geradora começa a transformar seu querogênio em petróleo em torno de $600^{\circ} \mathrm{C}$. No início, forma-se um óleo de baixa maturidade, viscoso. À medida que a temperatura aumenta, o óleo gerado vai ficando mais fluido e quantidade de gás vai aumentando. Por volta de $900^{\circ} \mathrm{C}$, as rochas geradoras atingem seu pico de geração, expelindo grandes quantidades de óleo e gás. Com o aumento da temperatura até os $1200^{\circ} \mathrm{C}$, o óleo fica cada vez mais fluido e mais rico em gás dissolvido. Por volta desta temperatura, a quantidade de gás é predominante e o óleo gerado já pode ser considerado um condensado. Entre $1200-1500^{\circ} \mathrm{C}$, apenas gás é gerado pelas rochas-fonte.

\section{Migração}

Uma vez gerado o petróleo, ele passa a ocupar um espaço/volume maior do que o querogênio original na rocha geradora. Esta se torna supersaturada em hidrocarbonetos e a pressão excessiva dos mesmos faz com que a rocha-fonte se frature intensamente, permitindo a expulsão dos fluidos para zonas de pressão mais baixa. A viagem dos fluidos petrolíferos, através de rotas diversas pela subsuperfície, até à chegada em um local portador de espaço poroso, selado e aprisionado, apto para armazená-los, constitui o fenômeno da migração. As rotas usuais em uma bacia sedimentar são fraturas em escalas variadas, falhas e rochas porosas diversas (rochas carreadoras), que ligam as "cozinhas" de geração, profundas, com alta pressão, a regiões focalizadoras de fluidos, mais rasas, com pressões menores.

\section{Trapa ou Armadilha}

Uma vez em movimento, os fluidos petrolíferos são dirigidos para zonas de pressão mais baixas que os arredores, normalmente posicionadas em situações estruturalmente mais elevadas que as vizinhanças. As configurações geométricas das estruturas das rochas sedimentares que permitem a focalização dos fluidos migrantes nos arredores para locais elevados, que não permitam o escape futuro destes fluidos, obrigandoos a lá se acumularem, são denominadas de trapas ou armadilhas. Elas podem ser simples como o flanco de homoclinais ou domos salinos, ou, mais comumente, como o ápice de dobras anticlinais/arcos/ domos salinos, ou até situações complexas como superposição de dobras e falhas de natureza diversas. Este tipo de aprisionamento, em uma estrutura elevada, é denominado de trapeamento estrutural.

Nem sempre o petróleo é aprisionado em situações estruturais. Eventualmente, a migração do petróleo pode ser detida pelo acunhamento da camadatransportadora, ou bloqueio da mesma por uma barreira diagenética ou de permeabilidade, ficando então retido em posições estruturalmente nãonotáveis. Neste caso, teremos um trapeamento de caráter estratigráfico.

\section{Rochas-reservatório}

Rochas-reservatório são normalmente litologias compostas por material detrítico de granulometria fração areia a seixo, representantes de antigos ambientes sedimentares de alta energia, portadores de espaço poroso onde o petróleo será armazenado e, posteriormente, será extraído. Tais rochas são geralmente os arenitos, calcarenitos e conglomerados diversos. Entretanto, qualquer rocha que contenha espaço poroso, não necessariamente intergranular, de natureza diversa causado por fraturamento ou dissolução também pode fazer às vezes de rochasreservatório. Como exemplos temos rochas ígneas e metamórficas cristalinas fraturadas, ou mais precisamente, qualquer tipo de rocha fraturada, mármores lixiviados, entre vários outros.

As rochas-reservatório mais comuns são areias antigas, depositadas em dunas, rios, praias, deltas, planícies litorâneas sujeitas à influência de ondas/ marés/tempestades, e em mares e lagos profundos, através de correntes de turbidez. Depois dos arenitos, os reservatórios mais comuns são rochas calcárias porosas depositadas em praias e planícies carbonáticas, desenvolvidas em latitudes tropicais e 


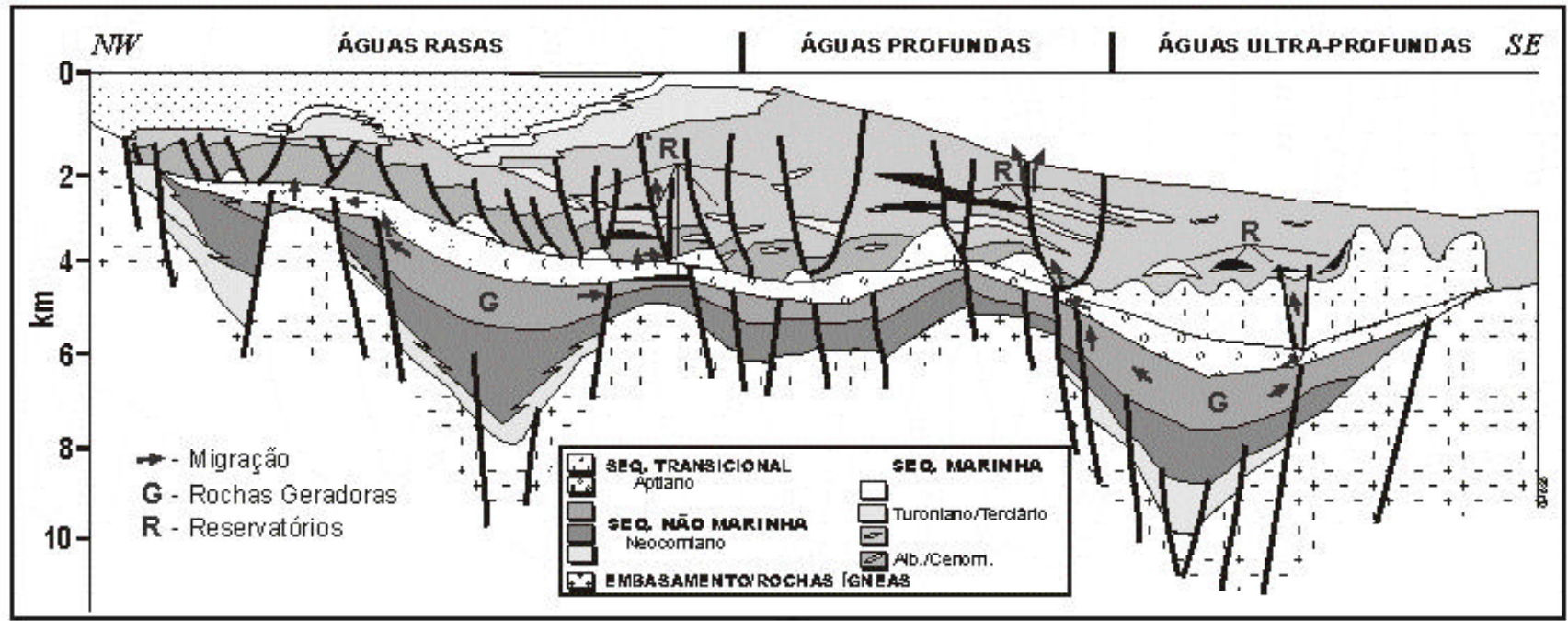

Figura 1 - Ilustração esquemática do sistema petrolífero atuante na Bacia de Campos (segundo Rangel \& Martins, 1998).

livres de detritos siliciclásticos, calcários de recifes de organismos diversos, e, finalmente, calcários diversos afetados por dissolução por águas meteóricas. Os valores de porosidade mais comuns das rochas-reservatório variam de 5\% - 35\%, concentrando-se na faixa de $15 \%$ - $30 \%$.

As rochas porosas não servem apenas como armazenadores finais do petróleo acumulado. Elas servem igualmente como rotas de migração importantíssimas para os fluidos petrolíferos, atuando como carrier beds.

\section{Rochas Selantes}

Uma vez atraídos para o interior de uma trapa ou armadilha, os fluidos petrolíferos devem encontrar uma situação de impermeabilização tal que os impeça de escaparem. Normalmente, esta condição é provida por rochas selantes, situadas acima das rochasreservatório, que impedem o escape dos fluidos, aprisionando-os e formando assim uma acumulação petrolífera.

Rochas selantes são normalmente de granulometria fina (folhelhos, siltitos, calcilutitos) ou qualquer rocha de baixa permeabilidade, cuja transmissibilidade a fluidos seja inferior à dos reservatórios a elas relacionados em várias ordens de grandeza (por exemplo, evaporitos diversos, rochas ígneas intrusivas). Eventualmente, mudanças faciológicas ou diagenéticas dentro da própria rocha-reservatório, ou mesmo elementos estruturais tais como falhamentos, poderão servir de selo para o petróleo.

\section{Sincronismo}

Sincronismo, no tocante à geologia do petróleo, é o fenômeno que faz com que as rochas geradoras, reservatórios, selantes, trapas e migração se originem e se desenvolvam em uma escala de tempo adequada para a formação de acumulações de petróleo. Assim sendo, uma vez iniciada a geração de hidrocarbonetos dentro de uma bacia sedimentar, após um soterramento adequado, o petróleo expulso da rocha geradora deve encontrar rotas de migração já formadas, seja por deformação estrutural anterior ou por seu próprio mecanismo de sobrepressão desenvolvido quando da geração. Da mesma maneira, a trapa já deve estar formada para atrair os fluidos migrantes, os reservatórios porosos já devem ter sido depositados, e não muito soterrados para perderem suas características permo-porosas originais, e as rochas selantes já devem estar presentes para impermeabilizar a armadilha.

Se estes elementos e fenômenos não seguirem uma ordem temporal favorável, o sincronismo, de nada adiantará a existência defasada de grandes estruturas, abundantes reservatórios e rochas geradoras com elevado teor de matéria orgânica na bacia sedimentar. 


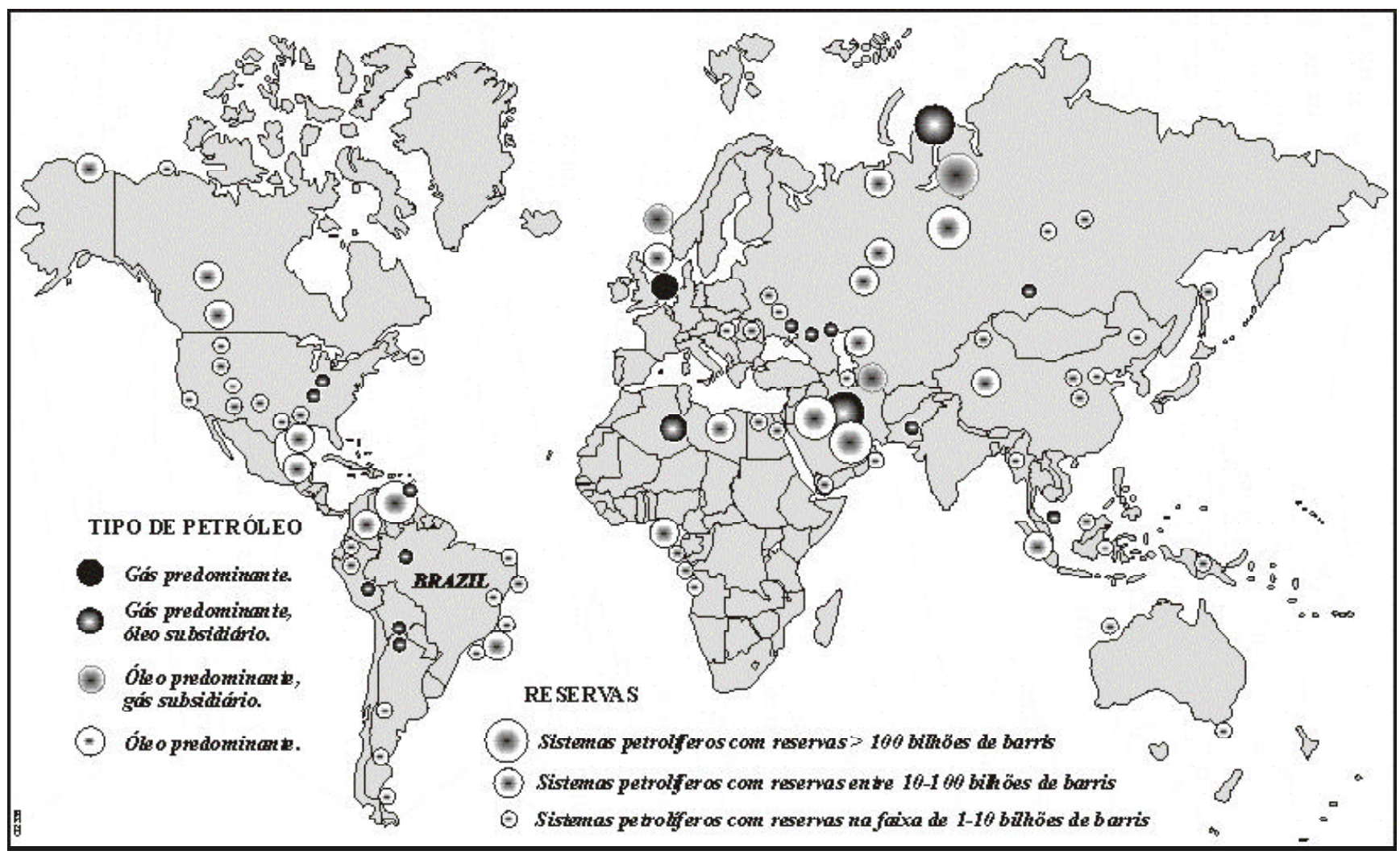

Figura 2 - Distribuição dos sistemas petrolíferos com maiores reservas de petróleo (exclusive águas profundas e ultraprofundas) do mundo. $\mathrm{O}$ tamanho do círculo é proporcional às reservas (petróleo recuperável) encontradas no sistema petrolífero. As áreas mais ricas são o Oriente Médio, a Bacia da Sibéria Ocidental e a Venezuela (Bacia de Maturin e Lago Maracaibo).

A falta de sincronismo entre os elementos componentes do sistema petrolífero tem sido uma das causas mais comuns no insucesso de perfurações exploratórias no mundo inteiro. A Fig. 1 ilustra o sistema petrolífero ativo na Bacia de Campos e responsável pelas maiores acumulações de petróleo já descobertas no Brasil.

\section{A DISTRIBUiÇão de PETRÓleO NO MUNDO}

A distribuição geográfica do petróleo no mundo é um dos fatos mais difíceis de ser entendido por pessoas leigas em ciências geológicas. Poucos países, normalmente cobertos por desertos ou por selvas e extremamente pobres em riquezas naturais superficiais, concentram a maioria das reservas petrolíferas do planeta. Já os demais países, situados em climas temperados e bem aquinhoados com outras riquezas naturais, possui uma fração muito pequena do petróleo mundial e, neste aspecto são implacavelmente dependentes dos países hegemônicos do petróleo, proprietários desta imensa riqueza em combustíveis fósseis. Isto se deve ao fato de que tal distribuição não guarda qualquer relação com geografia e sim com a geologia do subsolo, com a distribuição de bacias sedimentares formadas há dezenas ou até centenas de milhões de anos, e que nenhum compromisso guardam com os limites artificiais, políticos, impostos recentemente pela humanidade na superfície terrestre.

O conceito de sistema petrolífero apresentado acima explica o porquê de as regiões mais ricas em petróleo do planeta (Fig. 2) estarem concentradas em uma faixa grosseiramente Leste-Oeste, nas regiões sub-tropicais a sub-temperadas do hemisfério norte (América do Norte/Mediterrâneo/Oriente Médio/Ásia Central/Sudeste Asiático/Sudoeste Pacífico). A mesma rocha geradora rica em matéria orgânica (folhelhos neojurássicos), elemento base do conceito de sistemas petrolíferos, está presente no subsolo de toda esta faixa. O mesmo ambiente tectônico - colisão 
de placas continentais - deformou ou influenciou estruturalmente esta faixa. Os mesmos reservatórios - carbonatos juro-cretácicos - são abundantes ao longo desta faixa.

Este intervalo de tempo (Neojurássico e o início do Mesojurássico, 160 - 135Ma) engloba as rochas geradoras mais ricas conhecidas, estando elas relacionadas a um paleo-mar denominado de Tethys, que se desenvolveu em paleolatitudes quentes e equatoriais, desenvolvendo abundantes plataformas carbonáticas e camadas anóxicas repletas de matéria orgânica, mas que, posteriormente, foi destruído/ assimilado por sucessivas colisões continentais da Placa Eurasiana com várias outras vindas do sul, no final do Cretáceo e, principalmente, durante o Terciário. Uma longa cicatriz de montanhas e bacias sedimentares pouco ou muito amarrotadas, repletas de petróleo, marca a localização deste paleo-mar, outrora muito rico em matéria orgânica. .

De oeste para leste, aparece a província petrolífera de carbonatos do México, a oeste da Península de Yucatan (e em menor escala, Cuba) e o delta do Mississipi (uma feição sedimentar posterior que se desenvolveu de maneira fortuita sobre uma extensão paleo-setentrional da antiga rocha geradora do Mar de Tethys) no Golfo do México. Muito embora não tenha havido uma colisão continental nesta área, a interação entre a Placa do Caribe e a Placa NorteAmericana foi suficiente para fornecer um ambiente tectônico compressional ativo semelhante às colisões do outro lado do Atlântico.

A Placa Africana colidiu com a Europa formando as cadeias de montanhas do Atlas, Pirineus, Alpes (Itália/Suíça/Áustria e Dináricos) e Cárpatos. Muito embora as produções de petróleo destas áreas geologicamente conturbadas sejam pequenas, duas importantíssimas províncias petrolíferas se associam ao paleo-mar de Tethys na Europa. A Bacia da Sibéria Ocidental (Rússia), a segunda mais rica do planeta, e o Mar do Norte (Reino Unido e Noruega). Mesmo relativamente distantes da cicatriz atual do fechamento do paleo-mar neojurássico, e com desenvolvimento tectônico distinto da colisão continental ocorrente mais a sul (bacias intracratônicas constituídas por riftes aulacogênicos cobertas por depressões circulares tipo $s a g$ ), ambas áreas receberam transgressões marinhas paleo-setentrionais oriundas do paleo-mar de Tethys, à semelhança do Golfo do México. Ambas bacias sedimentares possuem em suas profundezas os ricos folhelhos

\begin{tabular}{|l|c|c|c}
\hline \multicolumn{1}{|c|}{ REGIÄO } & $\begin{array}{c}\text { VOLUME } \\
\text { PETRÓLEO } \\
\text { CONHECIDO } \\
\text { (bilhões de barris) } \\
\text { (Reserva + Produçä́) }\end{array}$ & $\begin{array}{c}\text { FRAÇĀO } \\
\text { MUNDIAL } \\
\text { (\%) }\end{array}$ & ROCHAS GERADORAS \\
\hline Oriente Médio & 980 & 35 & $\begin{array}{c}\text { JURASSICO. CENOMANIANO- } \\
\text { TURONIANO. SILURIANO. PERMIANO }\end{array}$ \\
\hline Sibéria Ocidental & 355 & 13 & JURASSICO \\
\hline Venezuela & 103 & 4 & CENOMANIANO-TURONIANO \\
\hline Volga-Ural & 81 & 3 & PERMIANO \\
\hline $\begin{array}{l}\text { Mar dn Norte } \\
\text { (central'norte) }\end{array}$ & 76 & 2,8 & JURASSICO \\
\hline Argélia/Líbia & 55 & 2 & SILURIANO \\
\hline Delta do Niger & 53 & 1,9 & PALEOCENOIEOCENOIOLIGOCENO \\
\hline México & 53 & 1,9 & JURASSICO \\
\hline Mar Cáspio (norte) & 46 & 1,7 & DEVONIANO \\
\hline Bacia do Sirte (Libia) & 44 & 1,6 & CENOMANIANO-TURONIANO \\
\hline Amu Darya & 40 & 1,5 & JURASSICO \\
\hline Mar do Norte (sul) & 40 & 1,5 & CARBONIFERO \\
\hline SUB-TOTAL & $\mathbf{1 9 2 6}$ & $\mathbf{7 0}$ & \\
\hline OUTROS & $\mathbf{8 4 1}$ & $\mathbf{3 0}$ & \\
\hline TOTAL MUNDO & $\mathbf{2 7 6 7}$ & $\mathbf{1 0 0}$ & \\
\hline
\end{tabular}

Tabela 1 - Doze regiões do planeta contêm 70\% do volume de petróleo descoberto até hoje. Do volume total (2.767 bilhões de barris), $37 \%$ (1.009 bilhões de barris) já foram produzidos e consumidos pela humanidade, restando ainda 63\% (1.758 bilhões de barris) como reservas conhecidas e produzíveis. 
geradores do Neojurássico, responsáveis pela maioria do petróleo ocorrente nestas duas áreas.

A região mais rica em petróleo é o Oriente Médio (vide Tabela 1). Arábia Saudita, Iran, Iraque e Kuwait dominam o cenário petrolífero mundial com as maiores reservas e maiores produções de petróleo. Seguem de perto os Emirados Árabes, Oman e Qatar. As principais razões geológicas para tal abundância são (i) a presença de rochas geradoras ricas, contínuas e extensas no Jurássico Superior (principal), Cretáceo e Siluriano, (ii) a existência de numerosas rochas carbonáticas porosas como excelentes reservatórios no Jurássico, Cretáceo e Terciário, além de arenitos igualmente porosos paleozóicos e terciários, e (iii) um tectonismo ativo, recente (Terciário) e relativamente simples, composto por diápiros salinos e estruturas compressionais relacionadas à colisão da Placa Arábica com a Placa Eurasiana ao longo das Montanhas Zagros. Relacionada ainda a este ambiente de rochas geradoras jurássicas ricas em matéria orgânica e reservatórios porosos jurocretácicos está a região situada entre o Mar Negro e o Mar Cáspio, posicionada do lado norte da colisão das Placas Eurasiana e Arábica. Através do Sudeste da Ásia (Paquistão, Afganistão e Índia, relacionados à colisão da Placa da Índia com a Eurasiana) e do Sudoeste do Pacífico (Papua-Nova Guiné e Noroeste da Austrália, relacionados à colisão da Placa Australiana com a Placa Pacífica) províncias petrolíferas de menor importância indicam ainda os resquícios da vasta área de ocorrência dos ricos folhelhos geradores neojurássicos.

Outras áreas clássicas ricas em petróleo estão relacionadas a outras rochas geradoras de idades diferentes. O Norte da América do Sul (Venezuela, Colômbia, Equador e Trinidad-Tobago), uma parte do Golfo do México (U.S.A.), a parte central dos Estados Unidos (bacias intermontanas e foreland das Montanhas Rochosas), a Bacia de Sirte na Líbia, norte do Egito e parte do Iran tiveram seu petróleo gerado nos folhelhos ricos em matéria orgânica depositados durante eventos anóxicos globais no CenomanianoTuroniano (96 - $88 \mathrm{Ma}$ ).

As bacias sedimentares sub-apalachianas dos Estados Unidos (a oeste dos Apalaches, onde se iniciou a indústria petrolífera, e a norte das montanhas Ouachita), as províncias gaseíferas do Rio Urucu na
Bacia do Solimões e da Argentina/Bolívia, a riquíssima região gaseífera da parte sul do Mar do Norte e Europa Ocidental, a região que abrange o Mar Cáspio e o lado ocidental dos Montes Urais, o norte da África (oeste da Líbia e Argélia) e parte da Arábia Saudita tiveram seu petróleo gerado a partir de folhelhos ricos em matéria orgânica de idades bem mais antigas, paleozóicas, principalmente do Siluriano (435 - 425 Ma), do Devoniano (400 - $355 \mathrm{Ma}$ ) e do Permiano (260 - $250 \mathrm{Ma}$ ). Rochas geradoras mais novas, do Terciário (65 - $5 \mathrm{Ma}$ ), são responsáveis pela riqueza de clássicas províncias petrolíferas tais como o Delta do Níger, as bacias interiores da China, as bacias offshore do Sudeste Asiático (Indonésia, Malásia e Filipinas), Califórnia, Golfo de Suez no Egito e algumas bacias interiores da Europa Central.

\section{O petróleo em águas profundas}

De 1985 para os dias de hoje, tem ocorrido uma acelerada busca pelas riquezas petrolíferas situadas em águas profundas (lâminas d'água superiores a $600 \mathrm{~m}$ ) e ultraprofundas (lâminas d'água superiores a $2000 \mathrm{~m}$ ) dos taludes e sopés das margens continentais de determinadas regiões do planeta. Esta corrida, motivada pelos contínuos aumentos do preço do petróleo impostos pelo mercado internacional, pelo decréscimo das reservas e produções de petróleo dos países industrializados e economicamente emergentes (USA, Canadá, Reino Unido, França, Itália, Brasil) e pela instabilidade política das principais regiões exportadoras de petróleo, trouxe consigo um desenvolvimento tecnológico sem paralelo na indústria petrolífera (hoje, com um retrospecto de atividades que alcança os 150 anos). Atualmente, a exploração e a produção de petróleo em águas profundas merece um capítulo à parte na história da indústria petrolífera mundial.

Motivados pelos baixos custos de descoberta destes grandes volumes de petróleo no offshore profundo e pela grande produtividade dos reservatórios turbidíticos (na casa de dezenas de milhares de barris por dia), a indústria petrolífera, liderada pela Petrobras, se lançou de maneira maciça na prospecção de petróleo nas águas profundas. Cerca de 12 bilhões de barris de reservas foram encontradas pela Petrobras na Bacia de Campos 
(Guardado et al., 1990). Esta bacia foi o laboratório mundial do desenvolvimento tecnológico que nestes quinze anos permitiu a entrada em produção de campos situados em lâminas d'água desde $400 \mathrm{~m}$ (Campo de Marimbá) até 1900 m (Campo de Roncador). O Golfo do México, liderado pela Shell, participou deste "corrida", fornecendo um grande número de descobertas que, embora apresentassem volumes significativamente inferiores aos da Bacia de Campos (cerca de 3 bilhões de barris de reservas), puderam ser colocados em produção pelo imenso mercado faminto de energia situado em suas adjacências e pela gigantesca infra-estrutura já existente em suas águas rasas. Vinte campos de petróleo situados, entre lâminas d'água entre 600 e 1600 m já entraram em produção no Golfo do México.

A costa oeste da África, notadamente nas águas profundas de Angola (delta do Congo) e Nigéria (delta do Niger), completa o chamado "triângulo dourado das águas profundas" (Fig. 3). Uma série impressionante de descobertas feitas por companhias como a Elf e a Total (hoje TotalFinaElf), Esso (hoje ExxonMobil), British Petroleum (hoje BP-Amoco) e Texaco já somam cerca de 8 bilhões de barris de reservas. Entretanto, o único campo em produção atualmente em lâminas d'água superiores a $600 \mathrm{~m}$ encontra-se na Guiné Equatorial (Campo de La Ceiba) operado pela pequena companhia Triton.

Outras áreas em franco desenvolvimento no número de descobertas e na perspectiva de entrada em produção de campos de petróleo em águas profundas são o sudeste asiático (Indonésia, Filipinas e Malásia), o Mediterrâneo (delta do Nilo no Egito e Israel, e Mar Adriático na Itália, este já com um campo em produção em 800 m de lâmina d'água), o Mar do Norte, Austrália, Trinidad Tobago e outros países da África Ocidental (Guiné Equatorial, Congo, Costa do Marfim e Mauritânia).

Nas águas profundas e ultraprofundas, a maioria dos sistemas petrolíferos ativos são deltaicos. As rochas geradoras podem ser folhelhos prodeltaicos (eocênicos-oligocênicos), existentes antes da progradação de grandes deltas oligo-miocênicos, tais como nos deltas do Niger, do Nilo e do Mahakam (Indonésia), ou folhelhos mais antigos, relacionados a depósitos anóxicos do Cenomaniano/Turoniano, cobertos igualmente por progradações deltaicas oligomiocênicas, tais como os deltas do Orinoco (Trinidad Tobago) e do Congo (Angola/Congo). No caso do delta do Mississipi, no Golfo do México, as rochas geradoras principais são os folhelhos neojurássicos, com uma significante contribuição dos folhelhos cenomaniano-turonianos. As rochas-reservatório são predominantemente arenitos turbidíticos, a deformação/trapeamento é do tipo compressional (relacionado a sistemas gravitacionais interligados de deslizamento-encurtamento) ou associado à tectônica salina e a subsidência necessária para a maturação e migração do petróleo é originada pela sobrecarga dos espessos pacotes deltaicos sobre as rochas geradoras subjacentes.

No caso particular da Bacia de Campos, o mesmo sistema petrolífero atuante nas águas rasas atua igualmente em águas profundas, ou seja, as rochas geradoras são folhelhos lacustrinos do Cretáceo Inferior e as rochas reservatório são turbiditos de idades diversas, variando do Albiano até o Mioceno (Fig. 1). A maturação necessária para a geração do petróleo parece estar ligada à progradação terciária do delta do rio Paraíba do Sul.

\section{Evolução Tectono-Sedimentar da Margem Continental Brasileira}

A margem divergente da América do Sul, estendendo-se por mais de $12.000 \mathrm{~km}$ desde o Delta do Orinoco no Oriente Venezuelano até a Terra do Fogo, no extremo sul da Argentina, inclui um sistema contínuo de bacias sedimentares originadas pelos mecanismos de distensão litosférica que, a partir do Mesozóico, conduziram à ruptura do paleocontinente Gondwana, e à separação definitiva das placas Africana e Sul-Americana, acompanhando a formação do Oceano Atlântico Sul.

Considerando-se a natureza e a orientação dos campos de tensões regionais durante a fase de rifteamento e a dinâmica das placas Africana e SulAmericana durante a fase de deriva continental, três domínios distintos (Fig. 4) podem ser reconhecidos ao longo da margem: uma região dominantemente distensiva, entre o sul da Argentina e o extremo nordeste da costa brasileira; um segmento de natureza transformante, correspondente ao Atlântico 


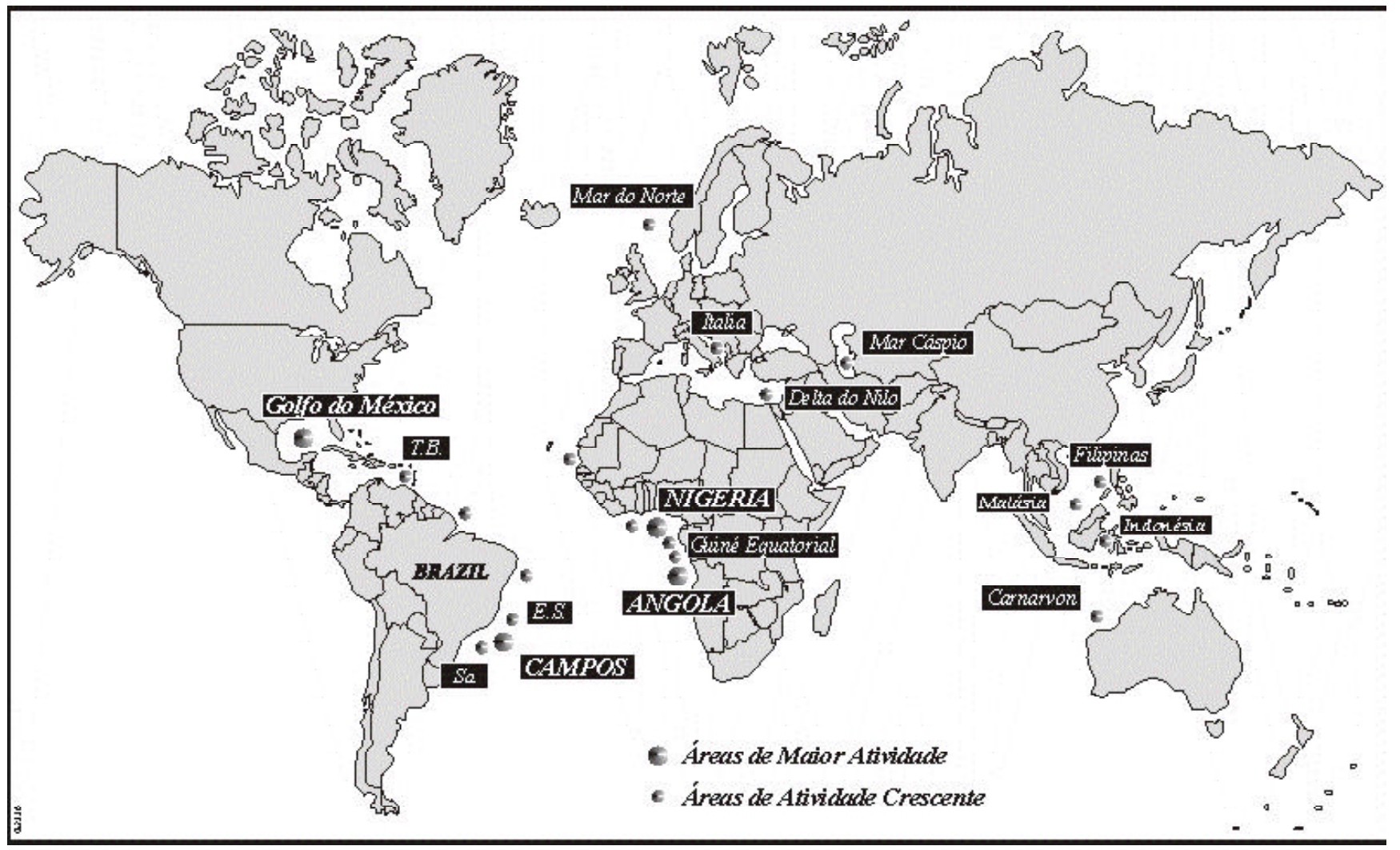

Figura 3 - Distribuição dos sistemas petrolíferos de águas profundas e ultraprofundas no mundo. O tamanho do círculo é proporcional às reservas encontradas. As áreas mais ricas são a Bacia de Campos, o Golfo do México e a África Ocidental (da Nigéria até Angola).

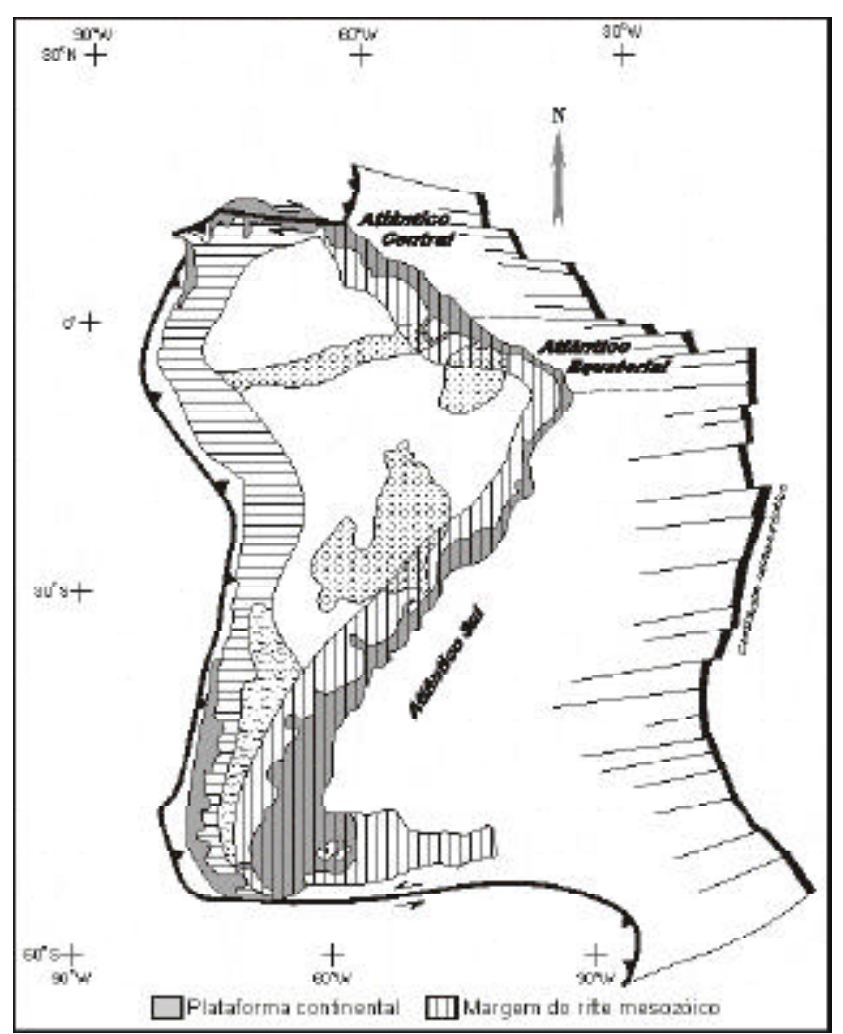

Figura 4 - A Placa Sulamericana e os domínios da margem atlântica.
Equatorial; e a região ao norte da Foz do Amazonas, onde novamente operaram processos de caráter dominantemente distensional (Milani \& Thomaz Filho, 2000).

No domínio distensivo meridional, o estilo estrutural durante a fase rifte foi marcado pela atividade de falhas normais orientadas principalmente na direção paralela à costa. Este estilo pode ser observado em cada uma das bacias individuais ao longo da margem (Ojeda, 1982; Chang et al., 1992). Falhas de transferência ocorrem a altos ângulos em relação à direção regional de desenvolvimento das falhas normais. O conjunto de falhas normais evoluiu e acabou por definir a orientação regional de abertura da margem passiva, e as zonas de transferência do rifte nuclearam as grandes falhas transformantes do assoalho oceânico, cuja projeção contra a borda do continente se dá em ângulo reto.

O estilo tectônico da margem adjacente ao Attântico Equatorial foi diferente (Zalán, 1985; Szatmari et al., 1987; Mascle et al., 1988; Matos, 2000). Cisalhamento dextrógiro foi o mecanismo responsável 


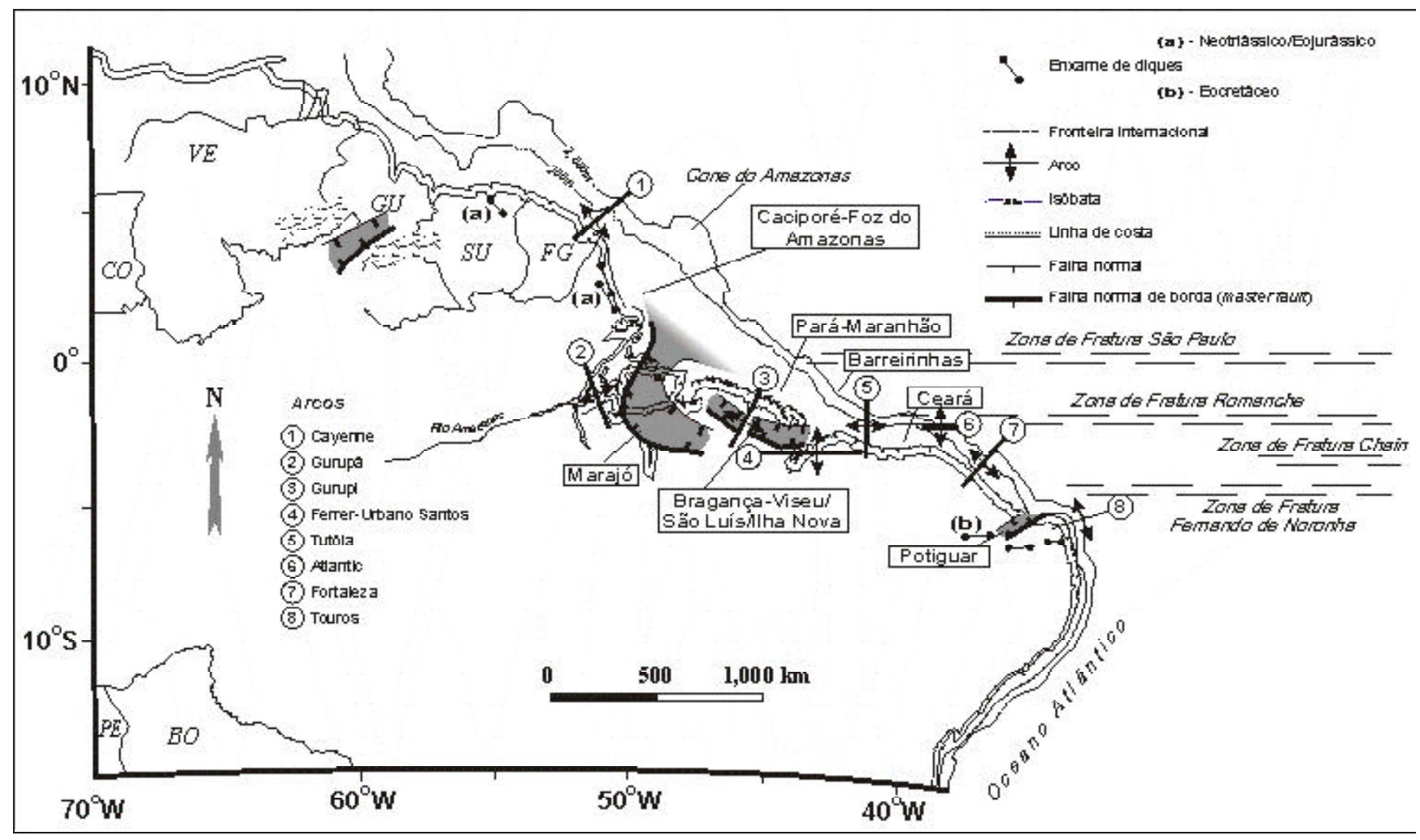

Figura 5 - Bacias sedimentares no contexto da Margem Equatorial brasileira.

pela ruptura crustal, originando um padrão de falhas oblíquas subverticais que controlaram o rifteamento e evoluíram para grandes zonas de fratura oceânicas paralelas à costa (Gorini, 1977), entre as quais incluem-se Fernando de Noronha, Chain, Romanche e São Paulo.

Uma terceira região na margem divergente da América do Sul corresponde ao trecho situado ao norte da Foz do Amazonas. Tal domínio faz parte de um outro contexto distensivo, o do Oceano Atlântico Central, mais antigo que o restante da margem uma vez que lá se encontram documentados processos de ruptura ativos já no Triássico.

Os vários setores individuais ou "bacias" ao longo da extensa e contínua margem divergente do continente compartilham algumas características comuns, como por exemplo os clássicos estágios tectono-sedimentares evolutivos que incluem o rifte, a fase transicional e a marinha aberta (Asmus \& Ponte, 1973). Entretanto, diferenças significativas ocorrem muitas vezes entre setores da margem, o que em parte justifica serem tratadas como entidades geológicas individualizadas.

\section{Segmento do Atlântico Central}

A porção da margem da América do Sul posicionada ao norte da Foz do Amazonas (Fig. 5), em que se inclui o segmento correspondente à costa do Estado do Amapá, constitui em termos geotectônicos a extremidade meridional do Oceano Atlântico Central, documentando em seu registro sedimentar-magmático o processo em grande escala de individualização, ruptura e separação entre as placas Norte Americana e Africana, ativo durante o Neotriássico e Eojurássico (Manspeizer, 1988).

A Bacia de Caciporé-Foz do Amazonas é bordejada a NW por um enxame de diques básicos aflorante, que corresponde ao registro desse episódio de ruptura. Alguns poços perfurados igualmente amostraram em subsuperfície rochas ígneas toleiíticas com idades radiométricas entre 222 e $186 \mathrm{Ma}$ (Brandão \& Feijó, 1994) que, associadas a red beds continentais, estão incluídas na Formação Calçoene. Um segundo - e de fato o mais importante - episódio de rifteamento na área teve lugar durante o Valanginiano ao Meso-Albiano, quando foram 
acumulados até $7.000 \mathrm{~m}$ de sedimentos sintectônicos e rochas ígneas associadas (125 Ma) em profundos grábens, constituindo a Formação Caciporé. O restante da seção cretácea-terciária é representado por pacotes siliciclásticos e carbonáticos; uma feição particular ocorre no intervalo pós-Mioceno em águas profundas: o Cone do Amazonas, um gigantesco leque sedimentar submarino com vários quilometros de espessura e constituído por argilas parcialmente inconsolidadas a que se intercalam depósitos de arenitos turbidíticos, potencialmente reservatórios para acumulações petrolíferas. As estruturas características na área do Cone do Amazonas são falhas lístricas de crescimento (distensivas), diápiros de argila e falhas de empurrão na porção mais distal dos grandes sistemas de escorregamento gravitacional.
A propagação triássico-jurássica no sentido sul do rifteamento do Atlântico Central teve como segmento terminal o rifte de Marajó. A Bacia de Marajó situase no Estado do Pará, sendo dominada em superfície pelos terrenos pantanosos das vizinhanças da foz do Rio Amazonas. É uma bacia com formato de meialua com $52.000 \mathrm{~km} 2$ de área, continuando para nordeste sob o Oceano Atlântico. Seu arcabouço estrutural inclui três depocentros: Mexiana, Limoeiro e Cametá. O primeiro orienta-se a SW-NE e constitui a conexão da bacia interior com a margem continental, exibindo um padrão complexo de dobramentos, falhas normais e transcorrentes com magmatismo associado (220-200 Ma). A sub-bacia de Limoeiro desenvolveu-se segundo um trende NW-SE, sendo a maior dessas sub-bacias; em seu depocentro, o embasamento encontra-se soterrado sob mais de

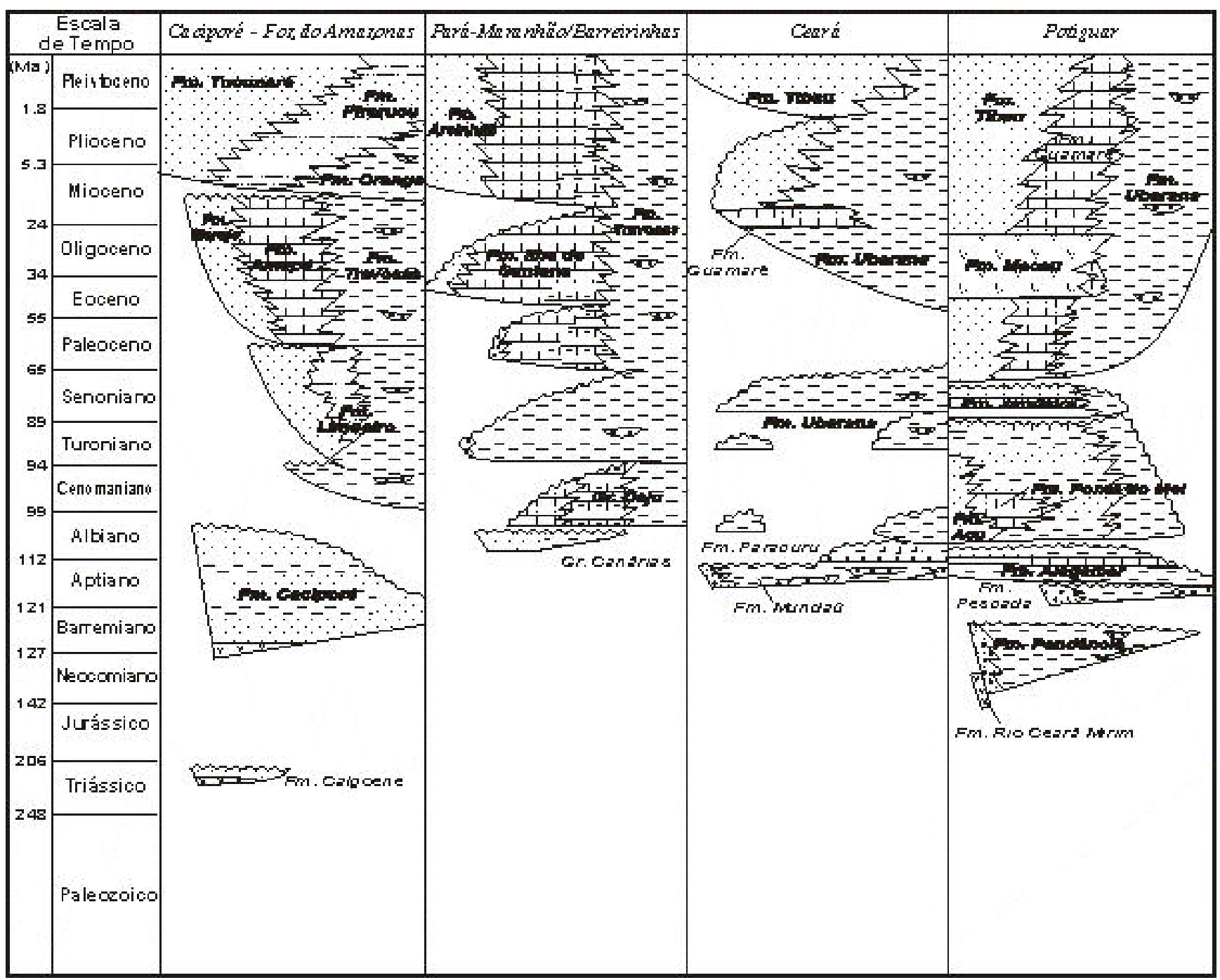

Figura 6 - Arcabouço estratigráfico da margem equatorial brasileira. 
$10.000 \mathrm{~m}$ de sedimentos. Grandes falhas normais sintéticas de geometria lístrica compõem seu arcabouço tectônico. A sub-bacia de Cametá representa a terminação SE deste rifte, tendo se implantado sobre as seqüências paleozóicas da Bacia do Parnaíba.

Com o declínio da atividade das falhas normais que caracterizaram a fase rifte, seguiu-se um estágio de $s a g$, a partir do Cenomaniano, quando foram depositados sedimentos predominantemente argilosos. Condições pós-rifte foram alcançadas no Maastrichtiano, e cerca de $4.000 \mathrm{~m}$ de sedimentos continentais a marinho-marginais foram acumulados (Formação Marajó). Uma grande parte desta sedimentação corresponde à descarga da bacia amazônica durante o Cenozóico.

\section{Margem Equatorial}

A tectônica transcorrente, peculiar na evolução da Margem Equatorial, impôs características específicas àquele segmento no que se refere à dinâmica do rifteamento e ao padrão estrutural das bacias sedimentares associadas. A arquitetura convencional das bacias do tipo rifte, onde a subsidência é controlada por uma importante falha normal de borda, a que se associam possantes leques de conglomerados sintectônicos, não é um padrão facilmente identificável nas bacias da Margem Equatorial (Matos \& Waick, 1998).

Estilos estruturais característicos de um rifteamento transtensivo ao longo desse limite de placas conduziram a uma evolução segmentada da Margem Equatorial, com sub-bacias apresentando entre si histórias contrastantes em termos de fluxo térmico, subsidência e distribuição de fácies sedimentares, magmatismo, eventos de soerguimento e episódios de deformação. Alguns setores da Margem Equatorial experimentaram subsidência contínua ao longo do tempo, similarmente ao padrão dominante na Margem Leste, ao passo em que outros foram submetidos a importantes episódios de soerguimento e inversão que produziram significativas lacunas em seus registros estratigráficos. Os dados disponíveis indicam que a fase rifte ao longo da Margem Equatorial ocorreu de forma rápida, no Aptiano (Matos e Waick, 1998), tendo sido a ruptura litosférica na região patrocinada por um binário de cisalhamento dextrógiro; em tal contexto de acelerada quebra e subsidência mecânica generalizada, incursões marinhas provenientes do Atlântico Central foram facilitadas, tendo influenciado a sedimentação já durante a fase rifte.

Quatro domínios ou "bacias" individualizadas são reconhecidas na Margem Equatorial Brasileira: ParáMaranhão, Barreirinhas, Ceará e Potiguar (Fig. 5). A Bacia do Pará-Maranhão, posicionada na faixa oceânica defronte aos estados homônimos e com área de $50.000 \mathrm{~km} 2$, tem como característica marcante em seu registro estratigráfico um espesso pacote de rochas carbonáticas, acumulados no intervalo de tempo entre o Maastrichtiano e o Recente e conhecidos como Formação Ilha de Santana. Este pacote carbonático grada lateralmente para uma sequiência arenosa proximal (Formação Areinhas). No sentido das águas profundas, dominam os folhelhos de talude e bacia a que se intercalam arenitos turbidíticos (Fig. 6).

A tectônica adiastrófica, propelida por fluxos de massa no sentido das regiões mais distais da margem continental, define um estilo de deformação bem característico, denominado por Zalán (2001) de gravitational fold-and-thrust belts. $\mathrm{O}$ fenômeno foi estudado em detalhe na região do Pará-Maranhão, e corresponde a um domínio com grande incidência de falhas de empurrão e dobras associadas, similares em geometria e dimensões aos clássicos cinturões orogênicos das áreas compressionais do planeta.

A Bacia de Barreirinhas, ocupando a porção costeira e de plataforma continental do Estado do Maranhão, tem área de $20.000 \mathrm{~km} 2$, dominantemente offshore. A bacia implantou-se em um substrato sedimentar paleozóico; o pacote rifte é representado pelo Grupo Canárias, uma seção de arenitos líticos imaturos, siltitos e folhelhos esverdeados, um conjunto de estratos interpretado como depositados num contexto deltaico preenchendo uma bacia rifte precocemente marinha. Seguem-se os grupos Caju e Humberto de Campos, documentando o estágio pósrifte na evolução da margem. O Grupo Humberto de Campos constitui o clássico complexo sedimentar de plataforma-talude-bacia, sendo que fácies de águas profundas, com arenitos turbidíticos associados, estão incluídas na Formação Travosas (Brandão \& Feijó, 1994). 
A Bacia do Ceará ocupa a porção oceânica defronte ao estado de mesmo nome, tendo área de $35.000 \mathrm{~km} 2$. Em função de particularidades nos estilos estruturais e estratigráficos, três segmentos são reconhecidos na bacia: de oeste para leste, as subbacias de Piauí-Camocim, Acaraú-Icaraí e Mundaú caracterizam diferentes domínios separados por importantes feições transversais positivas, correspondentes a altos do embasamento, a grandes corpos ígneos ou a anticlinais em ampla escala produzidos por inversão tectônica sin-sedimentar. Particularmente a sub-bacia de Piauí-Camocim (Zalán, 1985) caracteriza um complexo segmento da Margem Equatorial Brasileira onde operaram processos de inversão transpressiva, mecanismos estes os responsáveis pelo desenvolvimento de grandes hiatos no registro sedimentar daquela área, que envolvem o intervalo temporal entre o NeoCenomaniano e o Neo-Eoceno. O hiato equivalente nas regiões vizinhas a leste é de menor expressão, mas ainda importante em Acaraú-Icaraí, e torna-se quase imperceptível na sub-bacia de Mundaú.

A fase rifte acomodou mais de $4.000 \mathrm{~m}$ de sedimentos siliciclásticos continentais naquele segmento da margem, correspondentes a fácies de rochas aluviais, fluviais e lacustres da Formação Mundaú (Beltrami et al., 1994). A partir do Albiano, passaram a dominar condições francamente marinhas. Entre o Eoceno e o Recente, uma sedimentação arenosa grossa acomodou-se junto às áreas proximais da bacia, a Formação Tibau, que grada para os carbonatos da Formação Guamaré e aos folhelhos da Formação Ubarana no sentido das porções mais distais da bacia. Outro aspecto significativo observado na Bacia do Ceará, certamente ligado à presença de importantes lineamentos oceânicos em seu substrato, é a abundância de montes submarinos e guyots nas regiões de águas profundas.

A Bacia Potiguar constitui o segmento de ligação entre a Margem Equatorial e a Margem Leste, e ocupa área de $27.000 \mathrm{~km} 2$ na porção offshore e 22.000 $\mathrm{km} 2$ em terra. Por seu posicionamento geotectônico particular, este setor inclui elementos de ambos os contextos, o que lhe emprestou uma complexa evolução. O rifteamento iniciou no Neo-Berriasiano (Cremonini et al., 1998) como resultado de um campo distensivo WNW-ESSE, persistente até o Eo-
Barremiano. Um segundo pulso extensional, orientado a E-W, teve lugar entre o Neo-Barremiano e o EoAptiano. Seguiu-se uma fase transicional aptiana e a etapa de evolução marinha. No Neo-Campaniano, uma deformação transcorrente afetou a área, originando um padrão de estruturas orientado a WNW-ESSE e produzindo uma discordância de amplo significado na porção offshore da bacia.

No Cenozóico, teve lugar um magmatismo basáltico subaquoso, conhecido como Formação Macau. Eventos tectônicos tardios nesta área incluem reativações de feições estruturais NE-SW por campos de tensões E-W, cuja extensão ao Recente faz desta uma das regiões de maior sismicidade do País.

A porção terrestre da Bacia Potiguar inclui um gráben confinado, não-aflorante, que abriga sedimentos lacustres da fase rifte de idade neocomiana com espessura total de $6.000 \mathrm{~m}$. Recobre a seção rifte um pacote de rochas de idade aptiana a campaniana.

O arcabouço estrutural da calha central da Bacia Potiguar terra inclui depocentros ou grábens, altos internos e plataformas. Os grábens apresentam-se assimétricos com orientação geral SW-NE, desenvolvidos sob o controle de grandes falhas normais, sendo a principal delas a Falha de Carnaubais. Plataformas marginais rasas bordejam o gráben central em ambos os lados, e nessas áreas está ausente o pacote eocretácico. Falhas transcorrentes E-W afetaram a bacia durante $\mathrm{o}$ Barremiano-Eoaptiano. Uma persistente atividade magmática teve lugar durante a evolução do rifte Potiguar, e suas manifestações são conhecidas como Formação Rio Ceará-Mirim, datados entre 140-120 Ma (Araripe \& Feijó, 1994).

O pacote rifte na Bacia Potiguar é representado pela Formação Pendência, composta por folhelhos lacustres com turbiditos arenosos, arenitos flúviodeltaicos e conglomerados, abrangendo o intervalo temporal Berriasiano ao Eoaptiano. Este pacote limitase ao gráben central, sem afloramentos. O topo do pacote rifte é marcado por uma discordância regional, e a unidade encontra-se basculada para SE.

A Formação Alagamar, de idade Neoaptiana, recobre o pacote rifte. Ela representa o estágio transicional continental para marinho da evolução da 


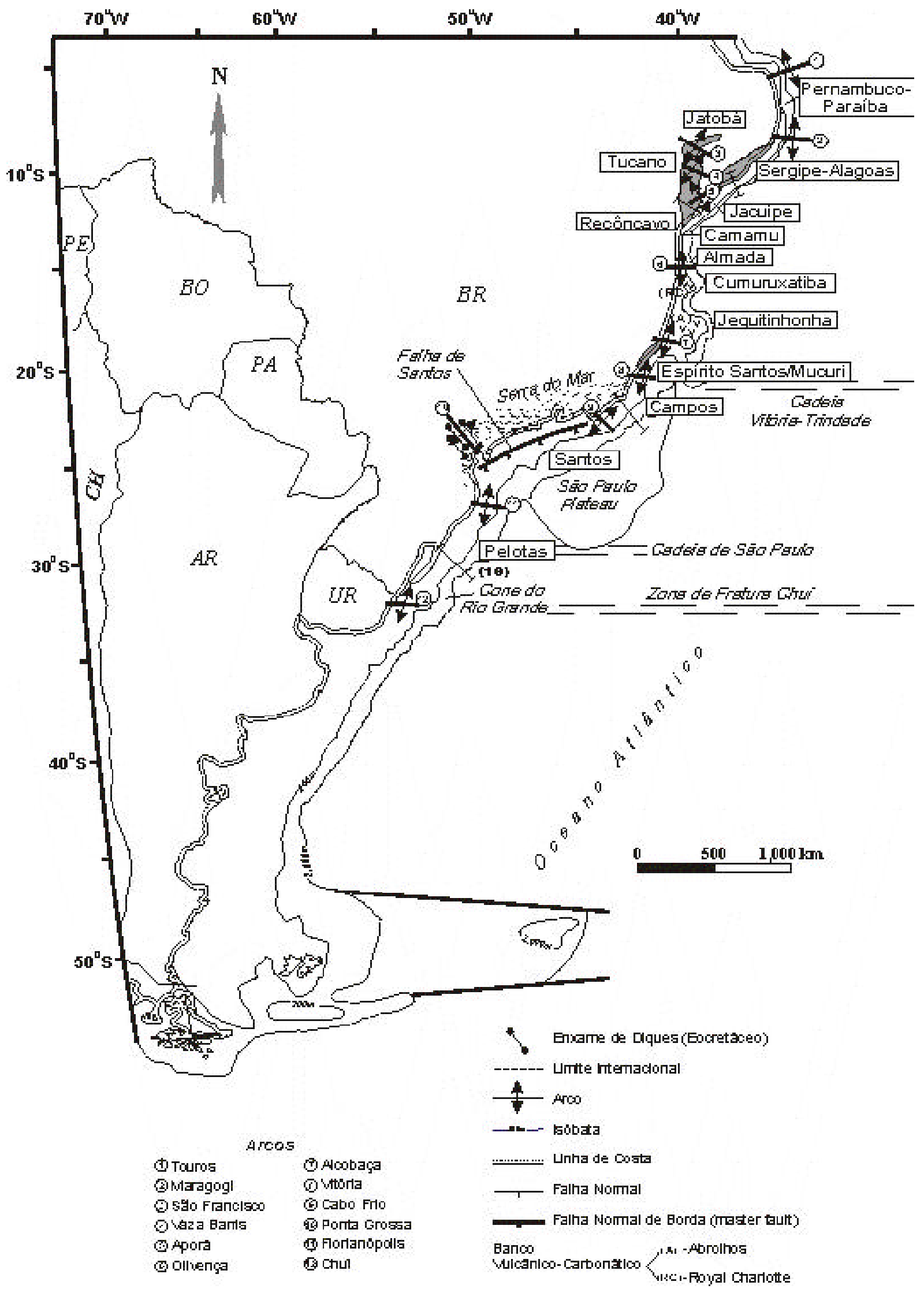

Figura 7 - Bacias sedimentares da margem leste brasileira. 
bacia, e consiste de folhelhos negros, margas e calcilutitos. Esta seção é recoberta por arenitos fluviais finos a grossos e argilitos de idade albo-cenomaniana (Formação Açu). Acima, ocorrem os carbonatos de alta energia da Formação Jandaíra, de idade turoniana-campaniana. Um recorrente magmatismo produziu, no Eoceno-Oligoceno, os depósitos da Formação Macau.

\section{Margem Leste}

O Neojurássico marcou o início do efetivo rifteamento na porção sul da América do Sul (Uliana \& Biddle, 1988; Urien \& Zambrano, 1996). Na porção meridional da Argentina, esta fase precoce de ruptura é documentada por alguns pulsos magmáticos mais antigos, datados entre 200 e 180 Ma (Keeley \& Light, 1993), indicando que o rompimento litosférico e a instalação da margem continental já eram iminentes. $\mathrm{O}$ arcabouço estrutural pré-existente, que inclui trendes de idade précambriana, paleozóica e triássica, exerceu um importante papel durante o rifteamento mesozóico, uma vez que a ruptura do Atlântico Sul acomodou-se como falhas normais sobre um grão estrutural mais antigo. Do mesmo modo, a presença de estruturas transversais criou complicações neste quadro simplificado de propagação do rifte de sul para norte.

A margem continental da América do Sul, vista a partir de seu extremo meridional, inicia com um extenso trecho retilíneo, orientado a NE-SW, em que inclui-se a Bacia de Pelotas (Fig. 7). Na terminação nordeste deste trecho desenvolve-se a Dorsal de São Paulo, cujo prolongamento para NW, no sentido do continente, encontra o Arco de Ponta Grossa. Esta feição corresponde a um braço abortado do rifte sulatlântico inteiramente dominado por magmatismo básico do Eocretáceo (134-128 Ma; Turner et al., 1994) que afeta os pacotes sedimentares paleozóicos da Bacia do Paraná e as regiões de embasamento vizinhas.

A Dorsal de São Paulo também define o limite sul do Platô de São Paulo, uma região onde a largura total da crosta distendida durante o rifteamento assume uma dimensão mais ampla quando comparada ao restante da margem. Nessa área, a crosta continental estirada alcança $400 \mathrm{~km}$ de largura, e sobre o platô alojam-se as bacias de Santos e Campos. No sentido do oceano, o Platô de São Paulo é limitado por uma escarpa abrupta, em parte correspondente também ao limite externo de ocorrência dos evaporitos aptianos. Para NW, o Platô de São Paulo é delimitado pela Serra do Mar, outra feição proeminente ao longo da margem leste brasileira. A configuração destas montanhas costeiras é dada por uma cadeia de escarpas com cerca de $1000 \mathrm{~km}$ de comprimento e 2200 metros de altitude máxima; seu trende SW-NE foi herdado do embasamento pré-cambriano.

Para norte do Platô de São Paulo, a margem brasileira extende-se por cerca de $1200 \mathrm{~km}$ numa direção N-S, até alcançar uma bifurcação no paralelo correspondente à Cidade do Salvador; aí se incluem as bacias do Espírito Santo-Mucuri, Cumuruxatiba, Jequitinhonha e Camamu-Almada. A partir da referida bifurcação, um ramo seguiu N-S continente-adentro, constituindo o rifte abortado do Recôncavo-TucanoJatobá, e o outro propagou-se ao longo da margem em desenvolvimento, definindo as bacias de Jacuípe, Sergipe-Alagoas e Pernambuco-Paraíba, até alcançar o Alto de Touros, no extremo nordeste do continente.

A Bacia de Pelotas ocupa cerca de 200.000 km2 na região costeira e marítima do Estado do Rio Grande do Sul, dos quais $40.000 \mathrm{~km} 2$ na área emersa. Em sua porção em terra, a Bacia de Pelotas inclui um pacote de rochas sedimentares siliciclásticas de idade terciária com até $1.800 \mathrm{~m}$ de espessura (Dias et al., 1994; Fontana, 1995).

O pacote sedimentar que preenche a Bacia de Pelotas assenta diretamente sobre o embasamento cristalino ou sobre seqüências paleozóicas equiivalentes às da Bacia do Paraná. O limite sul da bacia é dado pela Zona de Fratura do Chuy, junto ao limite territorial com o Uruguai. Para norte, a Plataforma de Florianópolis e a Dorsal de São Paulo constituem o limite entre as bacias de Pelotas e de Santos.

A fase rifte ocorreu durante o Neocomiano, e então se acumularam rochas siliciclásticas grossas da Formação Cassino associadas aos fluxos basálticos da Formação Imbituba (Fig. 8). No domínio de águas rasas, onde a morfologia do rifte é imageada pelos dados sísmicos, configuram-se meio-grábens controlados por falhas antitéticas de alto ângulo. Os basaltos da Formação Imbituba, num arranjo 


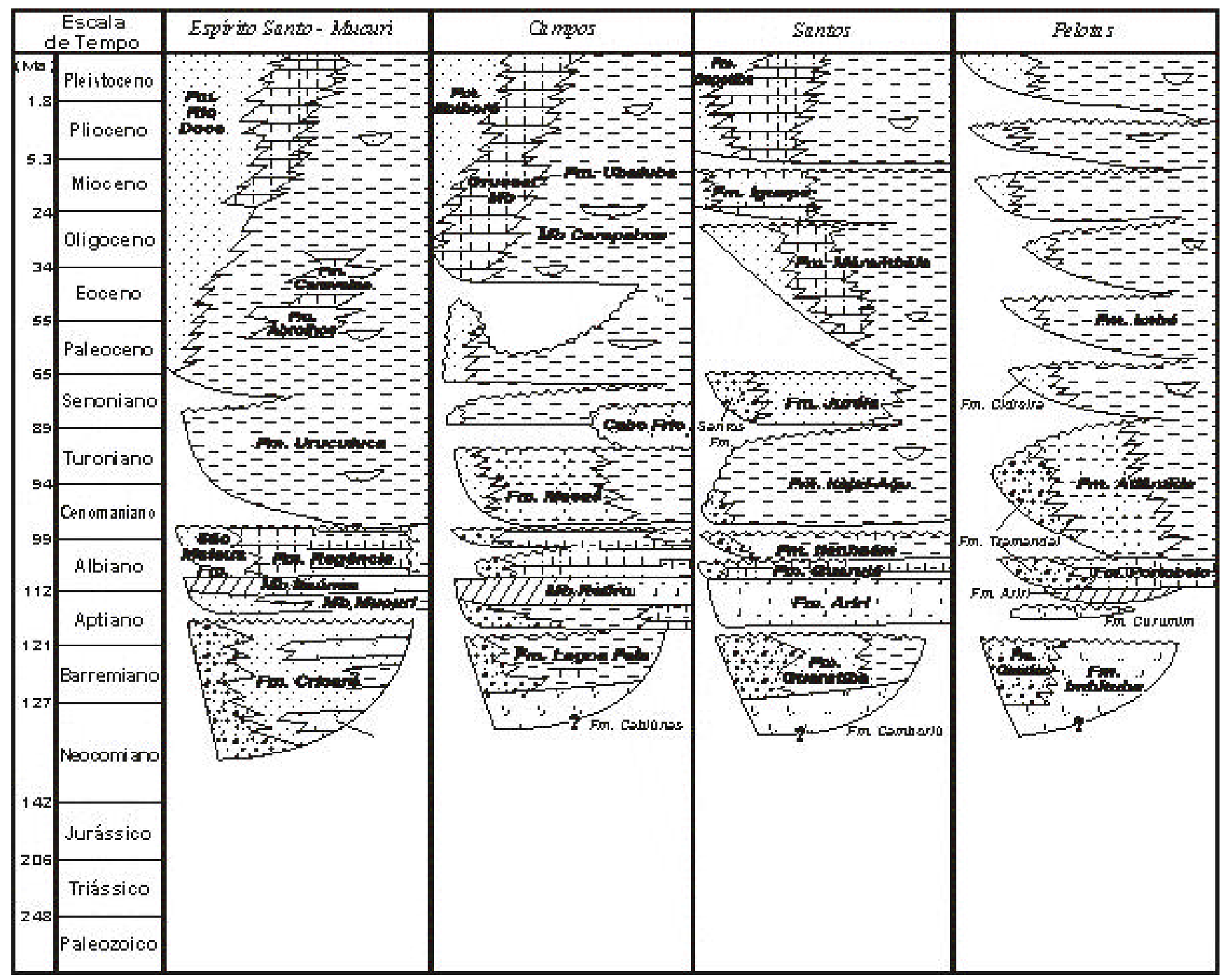

Fig. 8 - Arcabouço estratigráfico do segmento meridional da margem leste brasileira.

característico de seaward dipping reflectors (Fontana, 1990; 1995), tem idade K/Ar de 124 $\pm 8,6$ Ma (Dias et al., 1994), uma idade que se aproxima à do final do episódio magmático Serra Geral

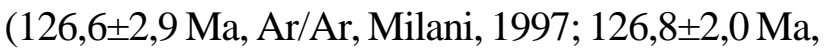
Ar/Ar, Turner et al., 1994). Esta relação cronológica parece indicar um importante deslocamento do centro magmático, do interior da placa para sua margem nascente.

O registro da sequiência evaporítica na Bacia de Pelotas é conhecido apenas na porção norte, sobre a Plataforma de Florianópolis, onde ocorre uma delgada unidade de anidrita e carbonatos (Formação Ariri), com $50 \mathrm{~m}$ de espessura, sobrepostos a traqui-

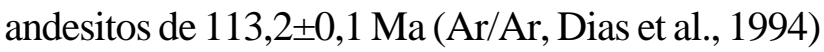
da Formação Curumim. A ausência de evaporitos emprestou à Bacia de Pelotas um aspecto monótono, pouco deformado, em claro contraste ao resto da margem brasileira.

Entre o Albiano e o Recente, predominaram condições de subsidência térmica. O Eoalbiano é representado pelo pacote carbonático da Formação Portobelo, de ocorrência restrita à porção norte da bacia, que é recoberto pela sucessão siliciclástica das formações Tramandaí e Cidreira. Estas unidades, abrangendo o intervalo temporal NeoalbianoRecente, constituem uma clássica cunha sedimentar com ermos arenosos junto à margem, gradando a siltitos e calcários de granulometria fina (Formação Atlântida) e folhelhos (Formação Imbé) no sentido das porções mais distais da bacia. O pacote supraPortobelo é recortado por uma série de superfícies erosivas que correspondem a tempos de queda relativa do nível do mar. Na porção sul da Bacia de 
Pelotas, ocorre um espesso pacote de sedimentos pós-Paleoceno com até 6000 metros, definindo o Cone do Rio Grande. Naquela área, são abundantes as estruturas ligadas à movimentação gravitacional de argila mergulho-abaixo, sendo comuns as ocorrências de hidratos de gás nos níveis estratigráficos mais superficiais (Fontana, 1989).

A Bacia de Santos é uma vasta porção da margem leste, com orientação geral SW-NE e geometria côncava, abrangendo cerca de 200.000 $\mathrm{km} 2$ do sudeste brasileiro. Para norte é limitada pelo Arco de Cabo Frio, e para sul pela Plataforma de Florianópolis, ambas sendo feições que se posicionam na terminação de lineamentos oceânicos expressivos (Cainelli \& Mohriak, 1998).

Para oeste, a Bacia de Santos é limitada pela Serra do Mar, uma feição fisiográfica que confina a bacia marginal ao domínio oceânico. $\mathrm{O}$ limite de ocorrência do pacote pré-Aptiano é dado por uma falha normal sintética posicionada a cerca de $50 \mathrm{~km}$ do litoral e cujo traço é paralelo à linha de costa. Este falhamento permaneceu ativo até o final do Cretáceo, tendo sido recoberto pelo pacote cenozóico durante a fase de subsidência térmica. A espessura total máxima do pacote Neocomiano a Recente é estimada em cerca de $11.000 \mathrm{~m}$.

A fase rifte na região de Santos ocorreu entre o Neocomiano e o Eoaptiano, quando acumularam-se os sedimentos lacustres da Formação Guaratiba, escassamente amostrados na bacia. Este pacote inclui cunhas de sedimentos siliciclásticos grossos avermelhados com fragmentos de basalto e quartzo, com coquinas associadas. A ocorrência de depósitos anóxicos é suposta para os domínios mais distais da bacia (Pereira \& Feijó, 1994).

A sequiência rifte é coberta pelos evaporitos aptianos da Formação Ariri, constituídos por intercalações de halita e anidrita. O fluxo mergulhoabaixo destes evaporitos, a partir do Albiano, definiu um estilo tectono-sedimntar em que são muito importantes as estruturas halocinéticas. Grandes diápiros e muralhas de sal alcançam vários quilometros de altura na região de águas profundas da Bacia de Santos.

A sucessão Albiana, conhecida como formações Florianópolis, Guarujá e Itanhaém, consiste de, respectivamente, arenitos avermelhados, carbonatos e folhelhos cinza, um conjunto lito-faciológico depositado durante um progressivo aprofundamento da bacia. As condições de máximo afogamento foram atingidas durante o Neocenomaniano-Turoniano, quando depositaram-se os folhelhos negros da Formação Itajaí-Açu. Nas regiões mais proximais da bacia, uma espessa cunha de conglomerados (Formação Santos) e arenitos de ambiente marinho raso (Formação Juréia), abrangendo o intervalo temporal entre o Santoniano e o Maastrichtiano, invadiram a bacia em resposta à subida da Serra do Mar. Este evento é datado entre 100 e 80 Ma por análise de traços de fissão de apatita (Lelarge, 1993). O restante da evolução da Bacia de Santos, já no Cenozóico, foi marcado por uma progradação de siliciclásticos (formações Iguape e Sepetiba), que avançaram sobre o sistema pelítico de plataforma e talude (Formação Marambaia).

A Bacia de Campos situa-se em águas territoriais do Estado do Rio de Janeiro, cobrindo cerca de $100.000 \mathrm{~km} 2$, dos quais apenas $500 \mathrm{~km} 2$ são em área emersa. Para norte, a bacia é parcialmente isolada da Bacia do Espírito Santo, na região de águas rasas, pelo Alto de Vitória, um bloco elevado de embasamento que coincide com a terminação oeste da Cadeia de Vitória-Trindade, um importante lineamento oceânico daquela área. Em águas profundas, não existe uma separação efetiva entre as bacias de Campos e do Espírito Santo.

O embasamento cristalino foi escassamente amostrado em subsuperfície, e corresponde aos mesmos domínios litológicos de gnaisses précambrianos que afloram nas áreas vizinhas à bacia marginal. Para o sul, o Arco de Cabo Frio limita a Bacia de Campos, e aquela região comportou-se como um foco de persistente magmatismo durante a história evolutiva da bacia. Naquela área, sedimentos turonianos a campanianos ocorrem intercalados a rochas vulcanoclásticas, basaltos e diques de diabásio de 90 a 80 Ma de idade. O magmatismo recorrente voltou a formar cones vulcânicos durante o Eoceno (Mohriak et al., 1995).

O pacote rifte da porção inferior da Formação Lagoa Feia na Bacia de Campos abarca o intervalo Neocomiano Superior-Barremiano, recobrindo e localmente interdigitando-se com os basaltos e rochas vulcanoclásticas da Formação Cabiúnas, datadas entre 
130 e 120 Ma (Dias et al., 1990). A porção inferior da Formação Lagoa Feia inclui conglomerados com abundantes clastos de basalto que formam grandes leques ao longo das falhas de borda; também ocorrem arenitos, folhelhos ricos em matéria orgânica e coquinas, definindo um contexto de sedimentação lacustre. As coquinas alcançam até $400 \mathrm{~m}$ de espessura, constituindo-se em depósitos de carapaças de pelecípodes (Membro Coqueiros) associados a altos estruturais e representando uma fácies particular de rochas porosas nesta bacia.

A parte superior da Formação Lagoa Feia, apoiada em expressiva discordância, é representada por uma sequiência de conglomerados e folhelhos avermelhados de idade aptiana recobertos por uma seção de evaporitos do Neoaptiano (Membro Retiro). A ocorrência do pacote aptiano e mais antigo é limitada por uma zona de falha sintética de orientação geral SW-NE que desenvolve-se paralela e próxima à linha de costa.

Durante o Albiano-Cenomaniano, as condições marinhas prevaleceram na bacia. A Formação Macaé consiste em carbonatos clásticos e oolíticos (Membro Quissamã) que, localmente, aparecem completamente dolomitizados. A sucessão vertical inclui calcilutitos, margas e folhelhos (Membro Outeiro) e arenitos turbidíticos (Membro Namorado). Nas porções mais proximais, a Formação Macaé é constituída por conglomerados e arenitos pobremente selecionados (Membro Goitacás).

O Grupo Campos recobre discordantemente a Formação Macaé, e representa o preenchimento desta bacia marginal durante a fase final de subsidência térmica e basculamento do substrato para leste. $\mathrm{O}$ pacote é representado por sedimentos proximais, areno-conglomerático-carbonático (Formação Emborê) que gradam a folhelhos nas porções distais (Formação Ubatuba). A Formação Ubatuba compreende milhares de metros de espessura de folhelhos e margas, com arenitos turbidíticos intercalados (Membro Carapebus).

O basculamento progressivo da bacia para leste propiciou o desenvolvimento de uma intensa deformação adiastrófica em função do volumoso fluxo de sal (Demercian et al., 1993). A tectônica salina e o estilos estruturais dela resultantes configuram dois casos: próximo à costa, nos primeiros 100 a 200 km, um regime francamente distensivo, que passa a um contexto compressivo na região de águas profundas, originada pela contração mergulho-abaixo do pacote em movimento. Falhas normais de geometria lístrica associam-se em geral à tectônica salina.

A Bacia do Espírito Santo-Mucuri situa-se na região costeira $(20.000 \mathrm{~km} 2)$ e na plataforma continental (200.000 km2) do Estado do Espírito Santo e porção sul da Bahia, tendo evoluído sobre um complexo de terrenos ígneos e metamórficos précambrianos (Vieira et al., 1994). As indicações mais antigas de processos distensivos mesozóicos ativos nessa área correspondem a diques de diabásio jurássicos orientados a NW-SE, conhecidos como Suíte Fundão. Esta fase precoce de magmatismo foi sucedida por um episódio extrusivo de idade neocomiana-barremiana, quando basaltos toleiíticos e rochas vulcanoclásticas da Formação Cabiúnas acumularam-se conjuntamente aos sedimentos iniciais da fase rifte na bacia.

O pacote sedimentar sinrifte da Bacia do Espírito Santo-Mucuri é conhecido como Formação Cricaré, tendo espessura estimada em $5.000 \mathrm{~m}$; corresponde a conglomerados continentais, arenitos, coquinas e dolomitos, associados a folhelhos ricos em carbono orgânico. A sequiência acomodou-se em depressões falhadas de orientação geral N-S a NE-SW, limitadas por falhas normais sintéticas, e seu topo é definido por uma importante superfície de discordância, sobre a qual se apoiam os sedimentos de natureza transicional da Formação Mariricu, do Neoaptiano. Esta unidade é formada por conglomerados, arenitos grossos arcosianos e folhelhos (Membro Mucuri) recobertos por um pacote de evaporitos e folhelhos negros conhecidos como Membro Itaúnas.

O pacote correspondente à fase marinha aberta na Bacia do Espírito Santo-Mucuri constitui o Grupo Barra Nova de idade albiana, e o Grupo Espírito Santo, abrangendo o intervalo Cenomaniano ao Recente. O primeiro consiste de arenitos grossos de fácies marinha marginal (Formação São Mateus) que grada para carbonatos no sentido do mar (Formação Regência). O Grupo Espírito Santo é a clássica sequiência de plataforma continental progradacional, formada por uma fácies arenosa proximal (Formação Rio Doce) intercalada com carbonatos (Formação Caravelas); o conjunto torna-se pelítico em seu 
contexto distal, junto ao talude e à bacia profunda (Formação Urucutuca).

O Cenozóico assistiu ao importante episódio magmático que definiu a Formação Abrolhos, impondo grandes rearranjos estruturais à bacia. Esta unidade corresponde a rochas vulcânicas e vulcaniclásticas sub-alcalinas a alcalinas que foram extrudidas durante o intervalo Paleoceno-Eoceno (60$40 \mathrm{Ma})$. Os corpos ígneos intercalam-se com os sedimentos carbonáticos da Formação Caravelas e com os folhelhos da Formação Urucutuca. A acumulação de grandes volumes de magma na porção externa da plataforma continental trouxe complicações ao quadro convencional de halocinese mergulhoabaixo; ao alcançar esta barreira, o fluxo sedimentar descendente construiu um padrão característico de estruturas compressionais junto ao Complexo de Abrolhos.

As Bacias de Cumuruxatiba/Jequitinhonha desenvolvem-se no domínio marítimo da costa da Bahia, correspondendo a um trecho retilíneo orientado a N-S, com cerca de $350 \mathrm{~km}$ de comprimento e uma área em torno de $45.000 \mathrm{~km} 2$. O embasamento nessa área é constituído por terrenos granítico-gnáissicos pré-cambrianos do Cráton do São Francisco. O padrão estrutural do rifte nestas bacias é dado por falhas normais sintéticas orientadas a N-S e SW-NE, localmente interrompidas por falhas de transferência e zonas de acomodação de direção NW-SE.

O pacote sedimentar neocomiano a eoaptiano nestas bacias corresponde ao Grupo Cumuruxatiba e à Formação Cricaré (Fig. 9). O primeiro inclui uma

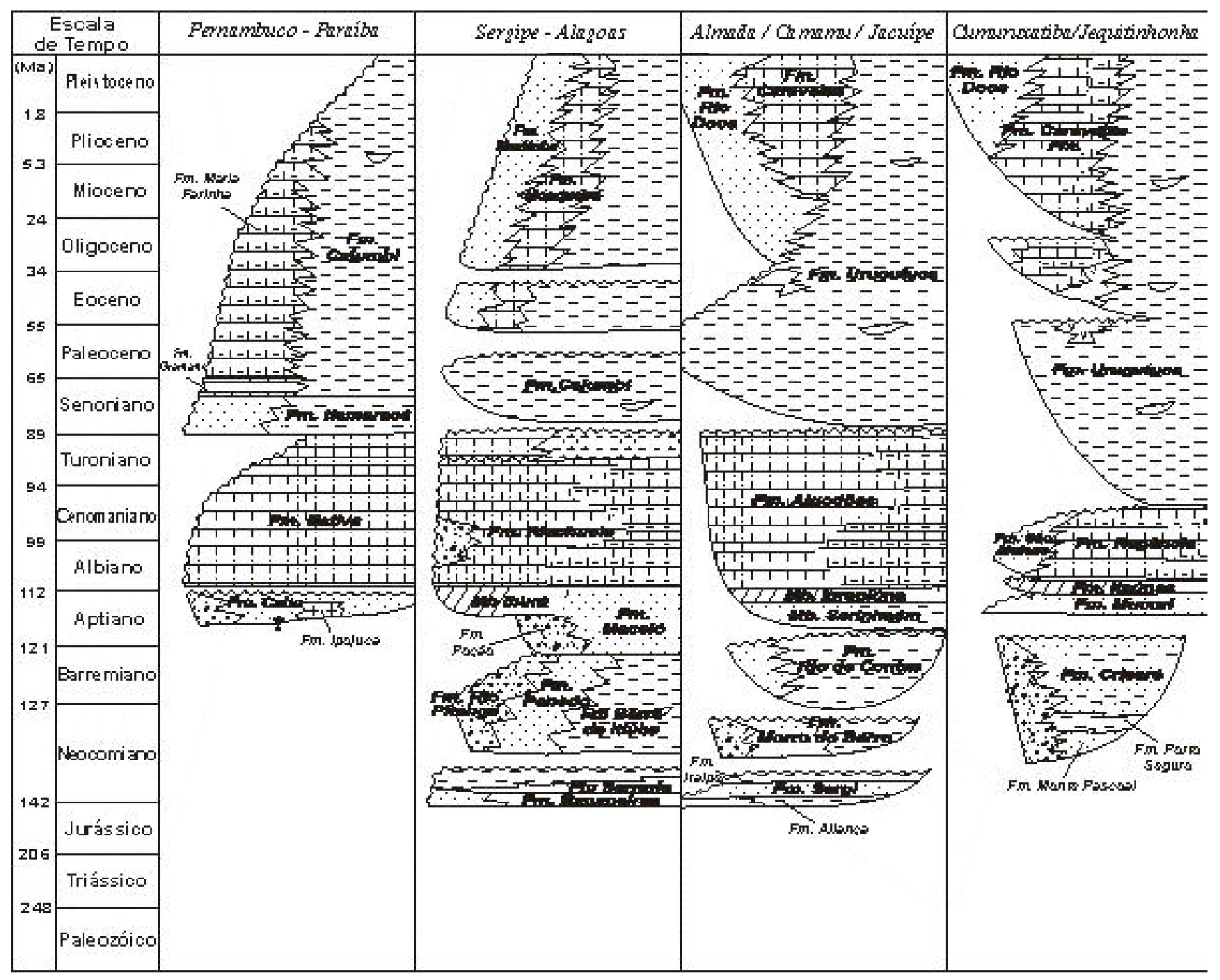

Fig. 9 - Arcabouço estratigráfico do segmento setentrional da margem leste brasileira. 
sucessão basal de rochas siliciclásticas (Formação Monte Pascoal) representada por arenitos grossos a médios intercalados com folhelhos cinza e pretos e conglomerados, interpretados como uma unidade prérifte. $\mathrm{O}$ pacote sinrifte é representado pela seqüência lacustre da Formação Porto Seguro (Santos et al., 1994) e Formação Cricaré. Esta última, bem como o restante do pacote lito-estratigráfico na área de Cumuruxatiba/Jequitinhonha, incluindo os magmatitos do Eocenozóico da Formação Abrolhos, exibe características similares às seções equivalentes encontradas na vizinha Bacia do Espírito SantoMucuri, pelo que tomam dela emprestada a nomenclatura estratigráfica formal.

As Bacias de Almada/Camamu/Jacuípe correspondem à porção da margem continental brasileira posicionada adjacente à Baía de Todos os Santos, no Estado da Bahia, cobrindo cerca de $110.000 \mathrm{~km} 2$, com apenas uma pequena parte em terra emersa. A Baía de Todos os Santos corresponde à terminação sul do rifte abortado do RecôncavoTucano-Jatobá, e à região onde essa bacia interior conecta-se com a margem. Isso define uma importante junção tectônica, marcada por um complexo padrão estrutural. Durante a evolução da porção norte da Bacia de Camamu, estilos estruturais distensivos e compressivos desenvolveram-se simultaneamente, num padrão singular ao longo da margem brasileira.

Alguns intervalos litológicos dessas bacias apresentam semelhanças ao encontrado nas seções equivalentes de áreas vizinhas, e assim delas obtiveram suas denominações litoestratigráficas. Este é o caso das unidades paleozóicas da Formação Afligidos e o pacote pré-rifte das formações Aliança e Sergi, unidades clássicas na estratigrafia da Bacia do Recôncavo. Acima dos arenitos da Formação Sergi assenta uma seção com cerca de $500 \mathrm{~m}$ de espessura de folhelhos avermelhados do Neocomiano inferior, conhecidos como Formação Itaípe e representando a transição pré-rifte/rifte na bacia (Netto et al., 1994).

A bacia sinrifte lacustre foi preenchida por folhelhos (Membro Jiribatuba) que gradam a arenitos nas regiões mais proximais (Membro Tinharé); no conjunto, estas unidades constituem a Formação Morro do Barro. Entre o Barremiano e o Eoaptiano, um pacote misto siliciclástico-carbonático de ambiente lacustre foi depositado, conhecido como Formação
Rio de Contas. Na Bacia de Jacuípe, o pacote Neocomiano está ausente e a Formação Rio de Contas representa o estágio rifte, que naquela área tem idade Barremiano-Eoalbiano.

Um pacote de evaporitos e siliciclásticos de idade neoaptiana constitui a Formação Taipus-Mirim. Esta unidade consiste de arenito muito fino intercalado com siltitos e folhelhos negros com elevado teor de carbono orgânico (Membro Serinhaém); o Membro Igrapiúna recobre a seção anterior e consiste de carbonatos, folhelho marrom, halita e anidrita, com barita associada em alguns locais nas bacias de Almada e Camamu.

A clássica seção de carbonatos albianocenomanianos é aqui conhecida como Formação Algodões, e é sucedida por uma seqüência neocretácica-cenozóica que, nas Bacias de Almada/ Camamu/Jacuípe, guarda similaridades litológicas e estratigráficas com as formações Urucutuca, Caravelas e Rio Doce da Bacia do Espírito SantoMucuri.

A Bacia de Sergipe-Alagoas situa-se na margem continental do nordeste brasileiro, cobrindo cerca de $35.000 \mathrm{~km} 2$, dos quais dois terços estão na área marítima. Das bacias da margem leste, a de SergipeAlagoas é a que registra a sucessão estratigráfica mais completa, incluindo remanescentes de uma sedimentação paleozóica, um pacote jurássico a eocretácico pré-rifte amplamente desenvolvido e as clássicas seqüências meso-cenozóicas sinrifte e pósrifte. A bacia é uma das tradicionais produtoras de petróleo do País e, juntamente com a Bacia do Recôncavo, escreveu as primeiras páginas na história da Geologia do Petróleo brasileira.

O Nordeste do Brasil foi um sítio de ampla sedimentação durante o Paleozóico, e provavelmente também durante o Neoproterozóico, o que é documentado pelas incontáveis áreas de ocorrência de remanescentes destas unidades que existem na região. Estas unidades foram preservadas de uma remoção erosiva por subsidência localizada devida à tectônica distensiva mesozóica. A Formação Estância é a mais antiga destas unidades, consistindo numa sucessão não-deformada de conglomerados, arenitos, folhelhos e carbonatos do NeoproterozóicoCambriano, exposta na porção sudoeste da bacia.

Remanescentes paleozóicos na Bacia de SergipeAlagoas são incluídos no Grupo Igreja Nova (Feijó, 
1994c). A Formação Batinga, de idade neocarbonífera, consiste de diamictitos, arenitos grossos e siltitos laminados acumulados sob condições glaciomarinhas; sua existência, no nordeste brasileiro, introduz complicações interessantes nos modelos paleogeográficos da glaciação gondwânica do permocarbonífero. A Formação Aracaré, também de idade paleozóica, é formada por arenitos vermelhos, folhelhos e carbonatos de idade eopermiana.

A seção neojurássica-eocretácica pré-rifte da Bacia de Sergipe-Alagoas corresponde ao Grupo Perucaba, sendo constituída por arenitos finos avermelhados (Formação Candeeiro) seguidos por folhelhos vermelhos (Formação Bananeiras) e arenitos médios a grossos, brancos e avermelhados com exuberantes estratificações cruzadas de natureza eólica (Formação Serraria).

O rifteamento nesse trecho da margem continental é interpretado como tendo sido resposta a um binário de cisalhamento sinistral (Milani et al., 1988; Milani \& Szatmari, 1998; Szatmari \& Milani, 1999), tendo o processo de ruptura litosférica sido completamente desprovido de magmatismo associado. Um conjunto de grábens orientados a N-S desenvolveram-se num padrão en échelon ao longo do strike geral SW-NE da bacia, e foram preenchidos por sedimentos neocomianos lacustres (parte inferior do Grupo Coruripe). Esta unidade também inclui conglomerados acumulados junto às falhas de borda (Formação Rio Pitanga), arenitos fluviais (Formação Penedo), uma sucessão heterolítica síltico-arenosa de origem deltaica (Formação Coqueiro Seco), coquinas de idade jiquiá (Membro Morro do Chaves) e folhelhos lacustres com arenitos lenticulares intercalados (Formação Barra de Itiúba).

Uma fase distensiva recorrente aconteceu durante o Eoaptiano, promovida por um campo regional orientado a NW-SE. Como resultado, desenvolveuse uma grande falha normal regional com trende geral SW-NE que aproximadamente coincide com a atual linha de costa, separando as porções emersa e marítima da bacia. A porção terrestre preserva uma seção sedimentar mais delgada, ao passo que nos grandes baixos deposicionais da parte offshore o pacote total alcança mais de $10.000 \mathrm{~m}$ de espessura. Esta segunda fase rifte foi também marcada pelo desenvolvimento de conglomerados da Formação Poção na Sub-bacia de Alagoas e pela parte inferior da Formação Maceió na Sub-bacia de Sergipe. Seguiu-se a acumulação dos evaporitos neoaptianos do Membro Ibura, correspondentes à porção superior da Formação Maceió.

Carbonatos albianos constituem a Formação Riachuelo, que gradam para fácies proximais arenoconglomeráticas (Membro Angico). O Grupo Piaçabuçu inclui as seqüências marginais marinhas do Neocretáceo ao Recente, correspondendo aos arenitos da Formação Marituba, carbonatos da Formação Mosqueiro e folhelhos com arenitos turbidíticos da Formação Calumbi. Localmente, segundo dados sísmicos, ocorrem corpos magmáticos intercalados ao pacote de idade naocretácicaeoterciária nos domínios distais da bacia.

A porção mais setentrional da margem leste brasileira corresponde à Bacia de PernambucoParaíba. A bacia ocupa $35.000 \mathrm{~km} 2$ de área, sendo $9.000 \mathrm{~km} 2$ em terra. Com respeito à inteira margem continental distensiva do continente, este é o trecho onde o rifteamento aconteceu por último, tendo a ruptura sido retardada até o Aptiano pela alta rigidez do embasamento pré-cambriano naquela área (Matos, 1998). A natureza da sedimentação na porção marítima da bacia ainda não foi amostrada por poços, sendo conhecida apenas com base em dados de sísmica.

A fase rifte foi muito rápida nessa área, tendo sua duração sido estimada em cerca de 5 Ma (Matos, 1998), durante o Neoaptiano. Nesse momento, foram depositados pelo menos $3.000 \mathrm{~m}$ de conglomerados e arenitos (Formação Cabo). Estas rochas sedimentares associam-se a rochas vulcânicas alcalinas e calco-alcalinas (Formação Ipojuca) e ocuparam o espaço de grábens abertos pelo evento distensivo. Seguiu-se uma fase de subsidência térmica, quando se acumularam os carbonatos albocenomanianos da Formação Estiva numa bacia marinha rasa.

Durante o Senoniano, implantou-se um sistema siliciclástico marinho marginal de arenitos grossos (Formação Beberibe) que geradam a siltitos e pelitos (Formação Itamaracá). Do final do Cretáceo ao Recente, carbonatos desenvolveram-se na bacia 
marginal rasa, um pacote que está incluído nas formações Gramame e Maria Farinha, que gradam para a Formação Calumbi nas porções distais.

Um aspecto particularmente interessante na geologia das bacias de Pernambuco-Paraíba é dado pela presença de boas exposições do contato $\mathrm{K} / \mathrm{T}$, uma condição não encontrada em outros locais ao longo da margem leste. Este intervalo estratigráfico foi estudado por Albertão (1995). Naquela área o contato $\mathrm{K} / \mathrm{T}$ corresponde a uma zona situada cerca de $60 \mathrm{~cm}$ acima do contato entre as formações Gramame, de idade maastrichtiana, e Maria Farinha, do Paleoceno-Oligoceno. O contato se expresssa como uma superfície erosiva que separa uma sequiência inferior de margas biomicríticas de ambiente nerítico e um pacote de carbonatos e folhelhos de ambiente mais profundo, caracterizados pela presença de estratificações cruzadas do tipo hummocky atribuídas à ação de tsunamis como modeladores do fundo marinho. Uma camada de marga apresentando um alto teor de irídio e de carbono orgânico marca o contato K/T e aqui, bem como a nível global, estes indicadores de extinção da biota pré-existente são interpretados como produzidos pelo impacto de um corpo extra-terrestre.

\section{A EXPLORAÇÃO DE PETRÓLEO NO BRASIL: DAS BACIAS TERRESTRES ÀS ÁGUAS ULTRAPROFUNDAS}

No momento em que uma nova ordenação jurídica para o setor petróleo recém se instala no País é oportuna uma reflexão sobre o petróleo, recurso natural tão disputado e de tão grande impacto na economia mundial. Pretende-se aqui, de forma sumarizada, registrar o esforço realizado na pesquisa do petróleo no Brasil desde suas origens, em meados do século 19, passando pelo século 20 e a criação da Petrobras, até o século 21, já sob a égide da Nova Lei e da Agência Nacional do Petróleo.

O petróleo e algumas de suas utilidades são conhecidos desde os tempos antigos, milhares de anos atrás; já foi utilizado como calafetante, iluminante (tochas fumarentas) e até como arma de guerra (fogo grego). Era obtido em exsudações, que são locais onde o petróleo, através de fraturas e fissuras nas rochas, extravasa na superfície. Foi usado por chineses, gregos, romanos, povos do Oriente Médio, no Egito dos Faraós, em várias civilizações antigas.

Desde a antiguidade até os tempos mais modernos, no século 19, sua utilização pouco se modificou, tendo inclusive adquirido nos Estados Unidos duvidosas qualidades medicinais. Por esta época, no mundo inteiro havia uma grande demanda por iluminantes mais eficientes que os óleos animais e vegetais então utilizados, e também por lubrificantes eficientes para as máquinas da recém-iniciada Era Industrial.

Uma conjunção de fatores e a visão de um grupo de americanos empreendedores, certamente almejando ganhar dinheiro, resultaram no evento que representa o marco inicial da Exploração de Petróleo, o ciclo de busca sistemática desse bem para utilização em bases industriais e comerciais. Um advogado, George Bissell, emigrando do Sul para o Norte dos Estados Unidos, por problemas de saúde, tomou conhecimento do petróleo minerado nas exsudações da Pensilvânia. Vislumbrando utilizações mais importantes que as medicinais da época para aquele produto, conseguiu convencer um banqueiro de Nova Jersey, que por sua vez encontrou investidores para o projeto. O próximo passo foi contratar um cientista, no caso o professor de química da Universidade de Yale, Benjamim Silliman, que comprovasse as qualidades idealizadas por Bissell para o petróleo. $\mathrm{O}$ cientista conseguiu, destilando aquele produto malcheiroso, comprovar a existência de vários subprodutos dentre os quais o querosene e a graxa, que se formavam a diferentes temperaturas.

Restava então descobrir um modo mais eficiente de extrair o petróleo. Existia na época, nos Estados Unidos, uma primitiva indústria de perfuração de poços artesianos para água e também para a obtenção de sal. Foi contratado um perfurador conhecido na época, o Coronel Edwin L. Drake, que orientou algumas modificações nos equipamentos existentes e foi encarregado da perfuração que teria lugar nas proximidades de Oil Creek, localidade do condado de Titusville, na Pensilvânia, famosa pelos seeps de petróleo. Foi encontrada a pouco mais de 20 metros de profundidade uma rocha-reservatório, de onde fluiu petróleo de boa qualidade, parafínico, de fácil destilação. (Fig. 10) Estava assim iniciada a Era do Petróleo, que moldou a maior potência da Terra, que originou fortunas, que motivou guerras pela sua posse 


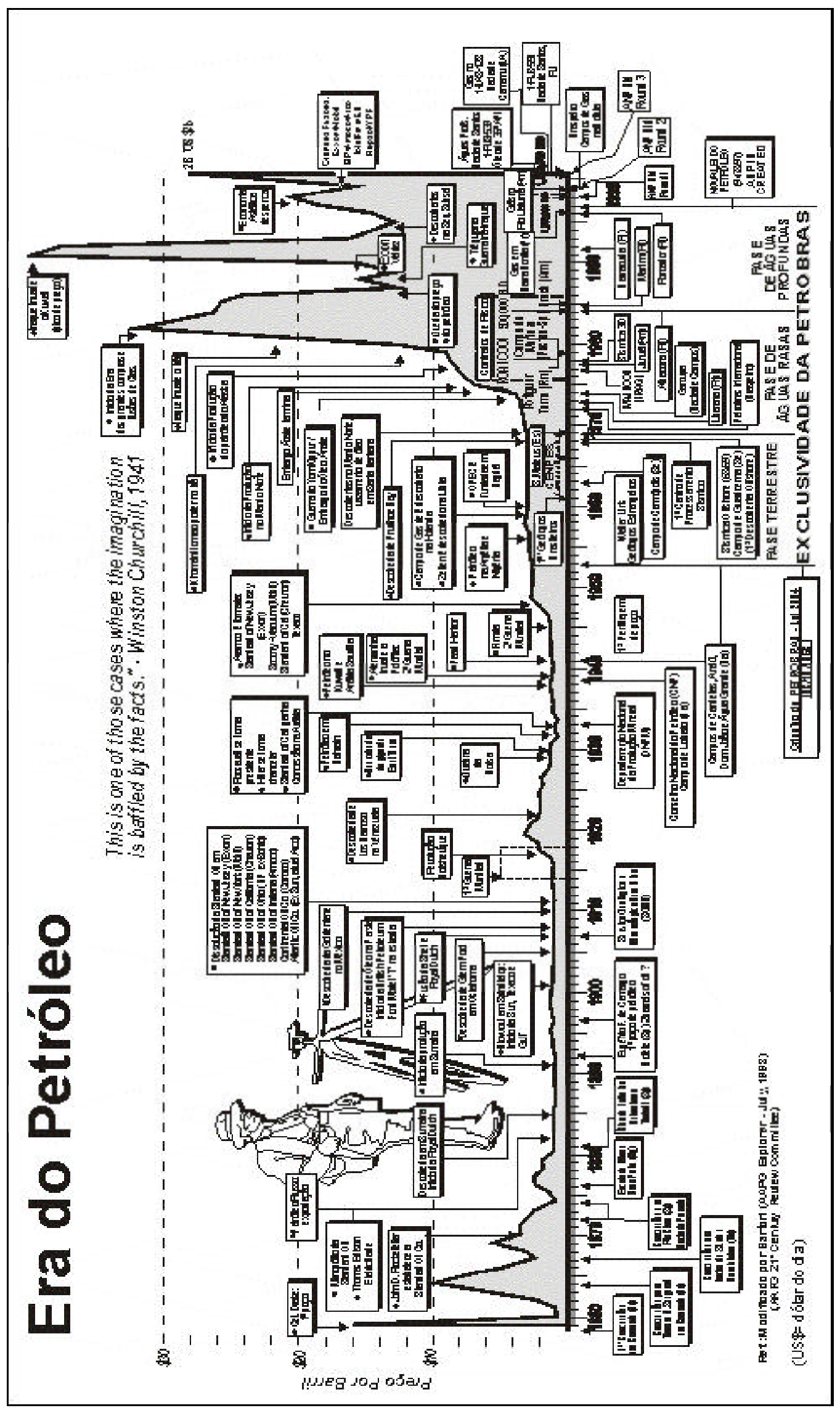

Figura 10 - A Era do Petróleo, vista sob a perspectiva da evolução do preço dessa commodity no mercado internacional. 


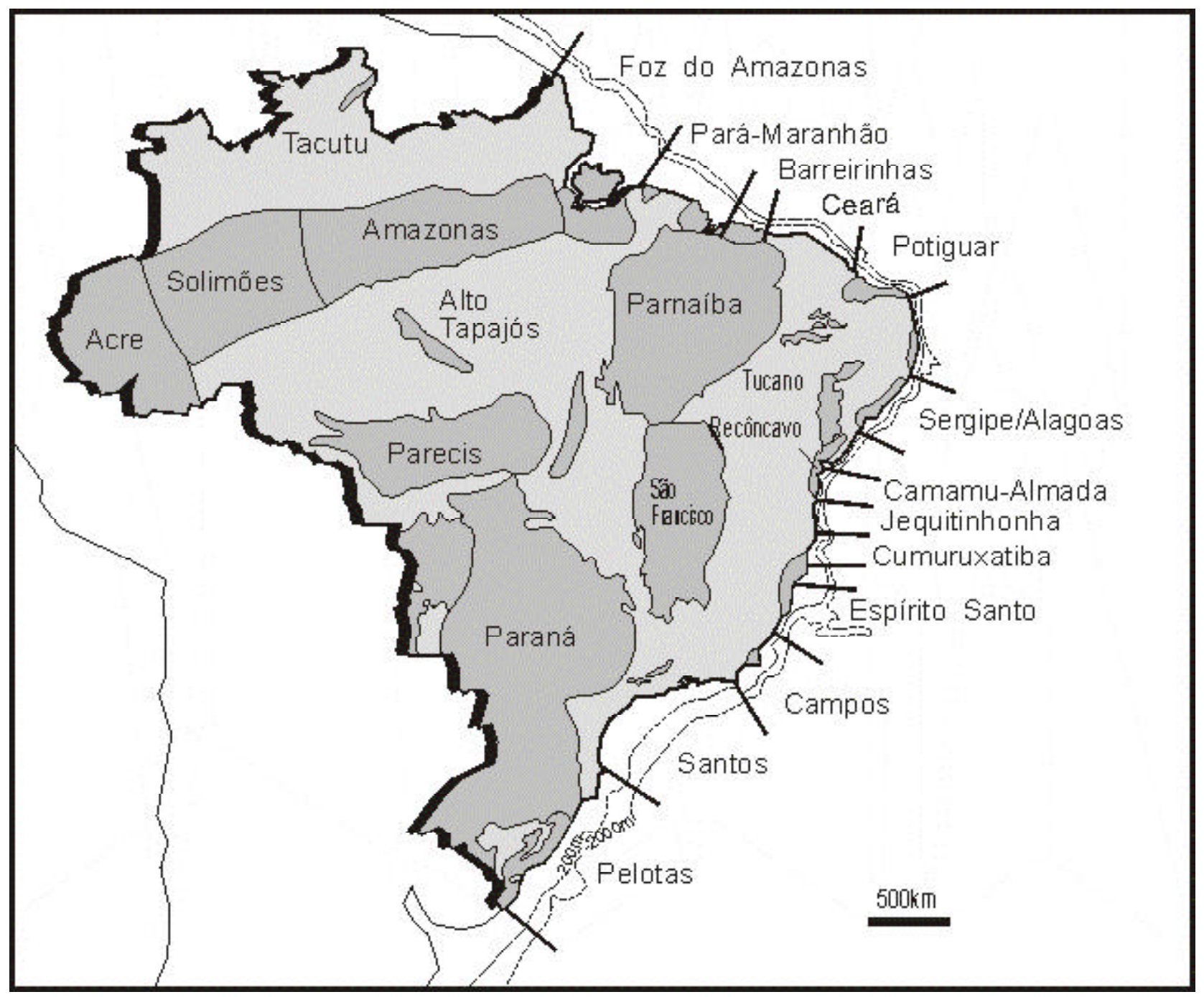

Figura 11 - Bacias sedimentares brasileiras.

e que se tornou o recurso mineral mais influente do século 21. O sucesso de Drake ficou como um marco inicial do crescimento explosivo da moderna indústria do petróleo.

No Brasil, a história também começou por esta época. Exsudações de petróleo e gás eram conhecidas em várias regiões do país, na Bahia, na hoje conhecida Bacia do Recôncavo Baiano, em São Paulo, Paraná e Santa Catarina, na Bacia do Paraná, no litoral baiano de Ilhéus, Bacia de Camamu, no Estado do Maranhão, Bacias de São Luiz e Barreirinhas, e em outros locais deste vasto paíscontinente. Os primeiros registros históricos, documentados, foram as duas concessões outorgadas em 1858 pelo Imperador Dom Pedro II a particulares, para a pesquisa e mineração de carvão, turfa e betume.
A partir daí, a história da exploração do petróleo brasileiro evoluiu por diversos períodos e fases influenciados e sustentados nestes 140 anos por um crescimento do conhecimento geológico, pelo aumento expressivo da demanda por derivados do petróleo, pela disponibilidade de recursos financeiros, pelos choques dos preços internacionais e pelos marcos regulatórios implementados. O evento mais importante no período foi a criação da Petrobras, com a responsabilidade de atuação exclusiva neste segmento da industria, uma aventura de sucesso que começou em terra, migrou para o mar, avançou com sucesso para as regiões de águas profundas (com cotas batimétricas entre 400 e 2.000 metros) e, desde 1999, iniciou mais uma etapa em uma nova fronteira, as regiões de águas ultraprofundas (mais de 2.000 metros de lâmina d'água). 
A promulgação, em 06/08/97 da lei 9478/97, a nova regulamentação do petróleo no Brasil, com a conseqüente implantação da Agência Nacional do Petróleo (ANP), encontram a atividade de exploração de petróleo em estágio crescente e maduro do conhecimento geológico de grande parte das diversas e complexas bacias sedimentares brasileiras. Possuindo grandes dimensões e uma área sedimentar total de $6.436 .000 \mathrm{~km} 2$, o Brasil conta, em terra, com mais de 20 bacias proterozóicas, paleozóicas, cretácicas e terciárias, algumas ainda inexploradas, espalhando-se por $4.880 .000 \mathrm{~km} 2$, desde o desenvolvido Sul-Sudeste até o árido Nordeste e a Amazônia (Fig.11). O restante da área sedimentar está na Plataforma Continental, onde $1.550 .000 \mathrm{~km} 2 \mathrm{se}$ distribuem por mais de 15 bacias sedimentares cretácico-terciárias de Margem Atlântica, até a cota batimétrica de 3.000 metros, desde o extremo sul, em águas territoriais limítrofes com o Uruguai, até o extremo norte, na fronteira com a Guiana Francesa. A região de águas profundas no mar brasileiro abrange $780.000 \mathrm{~km} 2$ entre as cotas batimétricas de $400 \mathrm{e}$ 3.000 metros.

Com uma população de cerca de 160 milhões de habitantes, o Brasil é uma das grandes economias do mundo, sendo a principal força econômica da América do Sul. Sua economia é diretamente influenciada pelos recursos energéticos encontrados em suas bacias sedimentares, principalmente aquelas da margem continental. Hoje, cerca de 38\% da energia primária consumida no País é proveniente do petróleo. Uma média diária de cerca de 1.500 .000 barris de petróleo (óleo + condensado + gás) são produzidos a partir das bacias sedimentares brasileiras, correspondendo a cerca de $70 \%$ das necessidades nacionais.

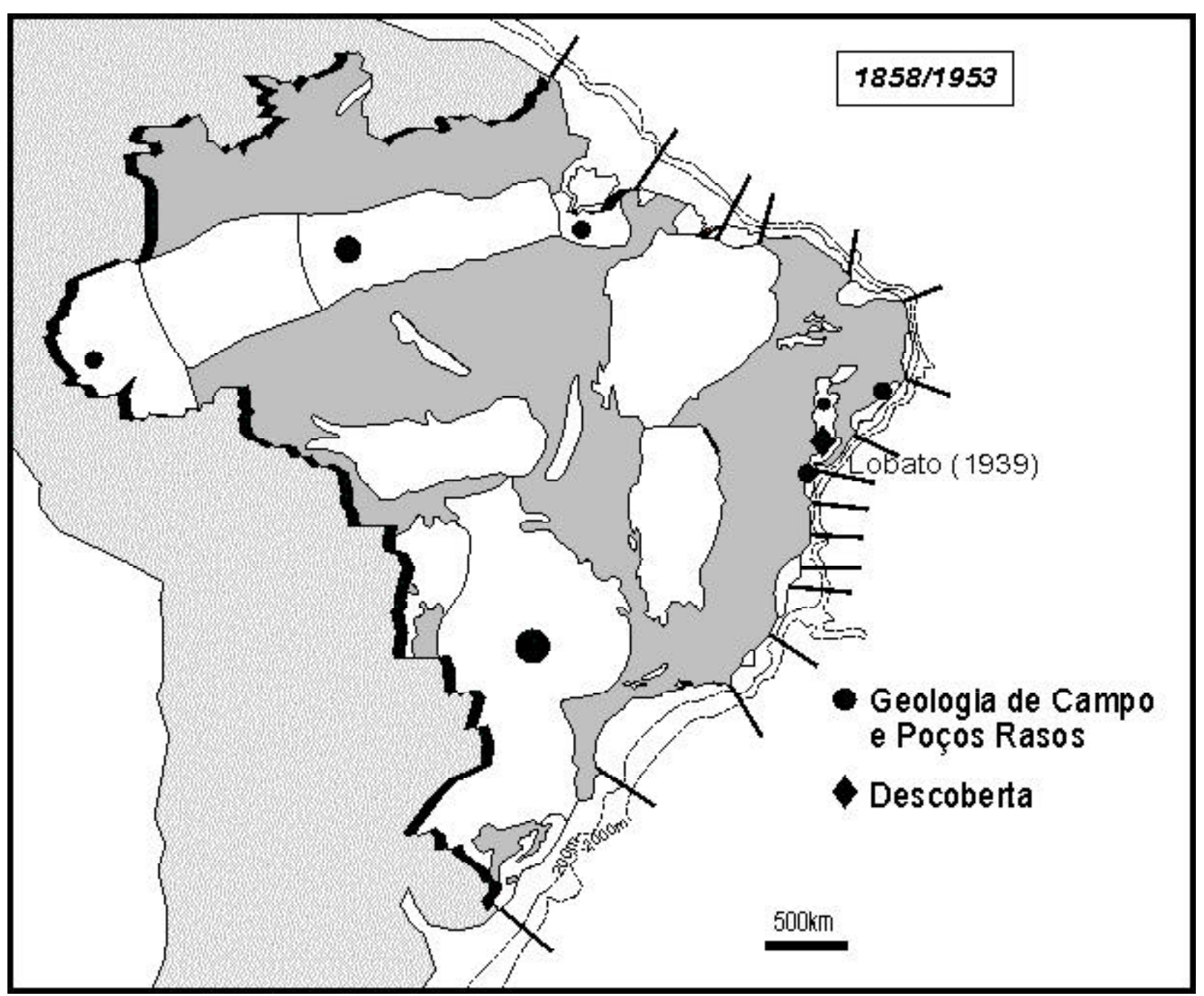

Figura 12 - Atividades exploratórias anteriores à criação da Petrobras. 


\section{A exploração no Período Pré-Petrobras}

Neste período, que se estendeu de 1853 até 1953 (Fig. 10), as áreas sedimentares brasileiras estiveram abertas à iniciativa privada. O início desta fase é marcado pelas duas primeiras concessões outorgadas pelo Imperador Dom Pedro II a particulares, em 1858, para a exploração de carvão, turfa e betume nos arredores do Rio Maraú, em Ilhéus, no estado da Bahia, região hoje conhecida como Bacia de Camamu, onde alguns seeps de óleo e a ocorrência de folhelho betuminoso eram conhecidos. Antes disso, sabia-se de maneira esparsa, não registrada, da existência de exsudações de óleo e gás em algumas regiões do Brasil.

A seguir, em 1859, foram descritos seeps de óleo em cortes da estrada de ferro em construção no Recôncavo Baiano, arredores de Salvador. Em 1864, Thomas Dennys Sargent requereu e recebeu concessão do imperador para a pesquisa e lavra de turfa e petróleo na mesma região de Ilhéus e Camamu. Em 1867, foram concedidos direitos de exploração de betume na região das bacias costeiras de São Luis e Barreirinhas. Entre 1872 e 1874, várias concessões foram registradas no interior do estado de São Paulo, nos arredores de Rio Claro, região da Bacia do Paraná conhecida pela ocorrência de exsudações de óleo e gás. Em 1876, com a fundação da Escola de Minas de Ouro Preto, em Minas Gerais, resolveu-se parcialmente o problema de mão-de-obra nacional especializada para suprir, com algum conhecimento científico, a busca do petróleo. Em 1881, a lavra e a retortagem do folhelho pirobetuminoso da Bacia de Taubaté proporcionaram combustível para a iluminação da cidade, por aproximadamente dois anos.

Porém, o marco mais importante desta época foi a perfuração, em 1892, na Bacia do Paraná, em Bofete, Estado de São Paulo, de um poço de petróleo que atingiu 488 metros de profundidade, um feito e tanto para o Brasil daquele final de século. Um fazendeiro de café de Campinas, Eugênio Ferreira de Camargo, entusiasmado com as notícias vindas do Estados Unidos a respeito do "ouro negro", obteve concessões na Bacia do Paraná, na região de Rio Claro e Botucatu. Inicialmente contratou um cientista belga chamado Auguste Colon, que provavelmente realizou os primeiros estudos geológicos de campo visando a ocorrência de petróleo no Brasil. Colon, ao final de seu trabalho, indicou duas áreas, em Bofete e em Porto Martins, onde duas possíveis estruturas geológicas poderiam conter petróleo. Camargo importou uma sonda americana, com um sondador experiente e mais alguns trabalhadores especializados, e o poço foi perfurado em Bofete, e de onde teriam sido recuperados dois barris de petróleo.

Em 1907, a criação do Serviço Geológico e Mineralógico Brasileiro (SGMB) resultou no aumento substancial da atividade de perfuração de poços, em bases um pouco mais profissionais. Sondas foram compradas e alguns geólogos e engenheiros de minas brasileiros fizeram parte da estrutura de pesquisa e perfuração para petróleo no SGMB. Em 1933, foi criado o Departamento Nacional da Produção Mineral (DNPM), porém a falta de recursos e peças de reposição para as sondas começou a causar problemas. A atividade de exploração de petróleo já estava mais organizada, graças ao SGMB e DNPM, porém a carência de recursos e a ausência de um órgão exclusivo responsável pelo Setor Petróleo, motivaram a criação do Conselho Nacional do Petróleo (CNP), em abril de 1939. Nesta época, o consumo brasileiro já causava uma dependência incômoda dos produtos estrangeiros. O CNP melhorou a estrutura da atividade de exploração de petróleo no Brasil e, após a primeira descoberta comercial em Lobato, preferiu inicialmente concentrar-se no Recôncavo Baiano.

Diante do entusiasmo causado por esta primeira descoberta, em pouco tempo os resultados começaram a aparecer. A partir de 1941, e até 1953, foram descobertos os Campos de Candeias, Aratu, Dom João e Água Grande, até hoje os maiores campos terrestres já descobertos no Recôncavo. Ao longo desta fase, a exploração se expandiu para o centro e porção norte da Bacia do Recôncavo, saindo das proximidades da Baía de Todos os Santos.

Este primeiro período de exploração de petróleo no Brasil teve como participantes alguns empreendedores privados (em boa parte financiados e utilizando equipamentos do governo), governos estaduais, SGMB, DNPM e, no final, o CNP. Caracterizou-se, principalmente no início, pelo 
amadorismo e falta de equipamentos e recursos, situação esta que melhorou sensivelmente com a entrada em cena do SGMB, do DNPM e, finalmente, do CNP.

A pesquisa de petróleo nesta fase utilizou como ferramenta principal a geologia de superfície, no início praticada por curiosos e sempre nas proximidades de seeps de óleo e gás. Com a criação do SGMB e DNPM, alguns geólogos e engenheiros de minas entraram em cena e, no final da fase, a geofísica começou a ser utilizada, principalmente nos arredores de São Pedro (SP), para a detecção de estruturas em subsuperfície. A partir da criação do CNP, a exploração passou a contar de forma mais rotineira com o auxílio já importante da sísmica e com sondas de maior capacidade de perfuração (até 2.500 metros). Foram perfurados 162 poços exploratórios terrestres rasos neste período, principalmente nas bacias do Recôncavo, Paraná, Amazonas e SergipeAlagoas (Fig.12).

Entre 1858 e 1938, nenhum resultado positivo foi reportado além dos registros dos seeps de óleo e gás e das ocorrências sub-comerciais de óleo e gás da região de São Pedro (Bacia do Paraná-SP), Riacho Doce (Alagoas) e Bom Jardim/Itaituba (Amazonas). Entre 1939 e 1953, entretanto, sob o comando do CNP, os resultados começaram a aparecer, tendo sido descobertos, após Lobato, outros 10 campos de petróleo, e as reservas nacionais alcançado 298 milhões de barris para uma produção diária de 2.720 barris. Em 1953, existiam cerca de 30 geólogos/geofísicos de petróleo no Brasil. Neste período, prevaleceram as condições inóspitas e sem infra-estrutura do interior brasileiro, valorizando ainda mais o trabalho e os resultados alcançados por estes primeiros exploracionistas brasileiros.

\section{O Período de exclusividade da Petrobras}

A Petrobras foi criada pela lei 2004 (03/10/1953), após longa e inflamada campanha popular, e instalada em 10/05/1954, para servir de base para a indústria do petróleo no Brasil e para exercer, em nome da União, o monopólio da exploração, produção, refino e comercialização do petróleo e seus derivados. Fez parte também de um ciclo histórico em que se visou montar as bases industriais brasileiras, pela criação de estatais nas áreas de metalurgia, siderurgia, estaleiros e petróleo. A empresa tinha como missão suprir o mercado interno com petróleo e seus derivados, através da produção nacional ou pela importação. O período no qual a Petrobras exerceu o monopólio do petróleo em nome da União pode ser dividido em várias fases distintas, que estão descritas a seguir.

\section{- 1954/1968: Fase Terrestre}

O inicio deste período (até 1961) se caracterizou pela instalação da Petrobras, pela presença maciça de técnicos estrangeiros e pela concentração de esforços no Recôncavo e na Amazônia, e, na sua segunda metade (1961/1968) pela presença cada vez maior de técnicos brasileiros e pela concentração de esforços ainda no Recôncavo, porém já se expandindo pelas demais bacias cretácicas costeiras.

Com o contínuo aumento no consumo, a dependência externa se agravou, apesar do baixo preço do barril de petróleo. Logo em seguida à criação da Petrobras, em 1953, uma decisão importantíssima foi tomada pelo comando da recém criada companhia: organizar o Departamento de Exploração nos mesmos moldes em que operavam as grandes companhias internacionais. Esta decisão resultou das mal sucedidas experiências anteriores, com órgãos estruturados de maneira pouco profissional e financeiramente instáveis. Foi contratado o geólogo Walter K. Link, veterano e bem conceituado no cenário da Exploração e Produção mundial, ex-profissional da Standard Oil Co., com as tarefas de organizar o Departamento de Exploração nos moldes industriais consagrados no restante do mundo, promover uma análise das bacias brasileiras para direcionar a exploração de petróleo nacional e ainda realizar as descobertas tão ansiosamente esperadas pelos brasileiros após a campanha "O Petróleo é Nosso".

Walter Link implantou na recém-edificada Petrobras uma estrutura organizacional nos moldes da indústria americana, fortemente centralizada. Técnicos estrangeiros, americanos e europeus, foram contratados maciçamente, enquanto geólogos/ geofísicos brasileiros foram enviados para treinamento e estudos no exterior. A sede da empresa foi instalada no Rio de Janeiro, com distritos operacionais em 


\begin{tabular}{|c|c|cc|}
\hline ANO & $\begin{array}{c}\text { GEÓLOGOS/GEOFISICOS } \\
\text { BRASILEIROS }\end{array}$ & $\begin{array}{c}\text { GEÓLOGOS/GEOFISICOS } \\
\text { ESTRANGEIROS }\end{array}$ & TOTAL \\
\hline 1954 & 19 & 0 & 19 \\
55 & 27 & 22 & 49 \\
\hline 56 & 46 & 37 & 83 \\
\hline 57 & 51 & 63 & 114 \\
\hline 58 & 64 & 72 & 136 \\
59 & 84 & 62 & 146 \\
\hline 1960 & 98 & 68 & 166 \\
\hline 61 & 131 & 54 & 185 \\
\hline 62 & 197 & 36 & 233 \\
63 & 256 & 26 & 282 \\
64 & 297 & 11 & 308 \\
\hline 65 & 323 & 8 & 331 \\
\hline 66 & 325 & 0 & 325 \\
\hline 67 & 321 & 0 & 321 \\
68 & 316 & 0 & 316 \\
69 & 286 & 0 & 286 \\
\hline 1970 & 275 & 0 & 275 \\
\hline
\end{tabular}

Tabela 2 - Histórico da força de trabalho de geocientistas da Petrobras no período 1954/1970. Até 1961, o norte-americano Walter Link chefiou o Departamento de Exploração.

\begin{tabular}{|l|c|c|}
\hline \multicolumn{1}{|c|}{ BACIA } & LINK & MOURA e ODDONE \\
\hline Baixo Amazonas & $\mathrm{D}$ & $\mathrm{D}$ \\
\hline Médio Amazonas & $\mathrm{C}$ & $\mathrm{C}+$ \\
\hline Alto Amazonas & $\mathrm{D}$ & $\mathrm{D}$ \\
\hline Acre & $\mathrm{D}+$ & $\mathrm{C}-$ \\
\hline Så̃o Luiz/Maranhão (Parnaíba) & $\mathrm{D}+$ & $\mathrm{C}-$ \\
\hline Barreirinhas & $\mathrm{D}$ & $\mathrm{B}$ \\
\hline Maranhăo/Piaui & $\mathrm{D}-$ & $\mathrm{C}$ \\
\hline Sergipe(terra) & $\mathrm{C}-$ & $\mathrm{B}$ \\
\hline Alagoas (terra) & $\mathrm{C}-$ & $\mathrm{B}$ \\
\hline ESiBahia Sul & $\mathrm{D}$ & $\mathrm{D}$ \\
\hline Sul do Brasil & $\mathrm{D}$ & $\mathrm{C}$ \\
\hline Recôncavo & $\mathrm{A}$ & $\mathrm{A}$ \\
\hline Tucano & $\mathrm{B}$ & $\mathrm{B}$ \\
\hline
\end{tabular}

Tabela 3 - Ranking de bacias sedimentares brasileiras segundo sua atratividade para petróleo, na visão de Link e de Moura \& Oddone. 
Belém, Maceió, Salvador e Ponta Grossa (PR). Inicialmente, foi feita uma revisão meticulosa das bacias conhecidas, ficando as ações concentradas nas bacias do Recôncavo (exploração e produção) e amazônicas (exploração), com esforço mais modesto nas demais bacias. A estratégia era imediatista: um aumento rápido da produção e de novas descobertas na já razoavelmente conhecida Bacia do Recôncavo, e realizar as grandes descobertas nas bacias da Região Amazônica, onde se concentravam nossas expectativas de redenção.

Uma dificuldade inicial foi a carência de pessoal especializado, apesar do CENAP (Centro de Aperfeiçoamento e Pesquisas de Petróleo) ter realizado alguns convênios com universidades brasileiras para formar geólogos de petróleo e do envio ao exterior de alguns técnicos brasileiros para estudos e especialização, mas isso não era suficiente. Dezenas de geólogos e geofísicos norte-americanos e europeus foram contratadas (Tab. 2), com a justificativa de que seriam os professores e instrutores dos técnicos brasileiros e, mais importante, a de que os resultados exploratórios só poderiam ser obtidos no curtíssimo prazo com a ajuda daqueles profissionais. O plano inicial era que, à medida que os profissionais brasileiros fossem sendo treinados, estes iriam substituindo os estrangeiros. Isto de fato aconteceu, e a tabela abaixo mostra como foi esta evolução.

Walter K. Link, à época renomado geólogo com reconhecida capacidade e experiência no ramo da exploração de petróleo, conhecia a indústria e as dificuldades das bacias brasileiras. Tendo aqui chegado com um cenário de óleo barato e com as expectativas nacionalistas exacerbadas pela campanha de criação da Petrobras ("O Petróleo é Nosso"), sabia da necessidade de se encontrar rapidamente os "bonanzas fields" (denominação utilizada no México e Sul dos Estados Unidos para campos gigantes), com campanhas exploratórias que se iniciariam rapidamente nas bacias mais apropriadas para estas descobertas. Daí, após uma meticulosa revisão de todas as bacias sedimentares brasileiras, os esforços terem sido divididos entre o óleo mais fácil e em quantidades modestas no Recôncavo e SergipeAlagoas e a busca dos "bonanzas" nas imensas bacias paleozóicas Amazônicas, do Parnaíba e Paraná.
Em 1955, um dos primeiros poços perfurados na Bacia do Médio Amazonas, região de Nova Olinda, produziu algum óleo, gerando grandes esperanças e intensificando a campanha amazônica. Em 1957, a descoberta da acumulação de Jequiá foi a primeira na Bacia de Sergipe-Alagoas e, também, a primeira fora do Recôncavo Baiano. A partir de 1960/61, as universidades brasileiras começaram a formar regularmente turmas de geólogos. Em 1961, os resultados negativos na Amazônia já começavam a causar algum desconforto e, neste mesmo ano, foi divulgado o Relatório Link (Link, 1960, apud Souza, 1997), que concluiu pela inexistência de acumulações de grande porte nas bacias sedimentares terrestres brasileiras.

De modo geral, a partir do relatório, Link questionava fortemente futuros investimentos em programas exploratórios muito audaciosos, desestimulando novas investidas nas bacias paleozóicas e recomendando a intensificação dos trabalhos no Recôncavo e Sergipe-Alagoas, principalmente na porção sergipana da bacia. É importante ressaltar que Link insistia que as conclusões apresentadas eram dependentes em grande parte dos escassos e pouco evoluídos dados geofísicos da época, e que a evolução desta ferramenta poderia reverter este quadro. Sugeriu ainda que o caminho para as grandes descobertas tão almejadas poderia estar na Plataforma Continental, àquela época já com atividade intensa e descobertas animadoras no Golfo do México americano, e também em concessões a serem adquiridas no exterior em bacias geologicamente mais atrativas. A polêmica despertada pelo "Relatório" na imprensa e nos meios políticos foi enorme, principalmente quanto ao pessimismo para com as imensas bacias paleozóicas brasileiras e devido ao mito criado da existência de petróleo em abundância no país. Um anexo ao relatório foi apresentado em novembro de 1960, com novas informações que rebaixavam as avaliações da Bacia do Médio Amazonas e da porção terrestre da Bacia de Sergipe-Alagoas, principalmente esta última (Alagoas).

O clamor nos meios jornalísticos e políticos aumentou, levantando inclusive suspeitas acerca da idoneidade na condução da política exploratória. Tudo isto coincidiu com a mudança do governo brasileiro e 
teve repercussão na direção da empresa, tendo sido trocado o General Sardenberg pelo engenheiro Geonísio Barroso. Nos meios técnicos também houve reação ao relatório, porém esta reação se prendeu mais ao que foi considerado pessimismo exagerado com relação a certas bacias frente a escassa quantidade de dados. Os argumentos dos exploracionistas que criticavam o Relatório se referiam em grande parte à metodologia, já que achavam que muito pouco trabalho de detalhe havia sido feito até então para avaliações tão negativas.

Em meados de 1961, ao término de seu contrato e ressentido com as críticas, muitas delas injustas e irrefletidas, a respeito do seu trabalho, Walter K. Link deixa o país, após demitir-se. Às acusações de máfé, por se "encontrar a serviço de interesses alienígenas", Link comenta simplesmente: "não sou eu quem fez a geologia das bacias sedimentares brasileiras".

Em março de 1961, antes da saída de Link, foi criado por decisão da diretoria um grupo de trabalho composto pelos geólogos Pedro de Moura e Décio Oddone, para a reavaliação do Relatório Link. Após a demissão do geólogo Link, Pedro de Moura foi empossado como chefe do Departamento de Exploração.

O novo relatório de reavaliação das bacias de modo geral contra-argumentava que até então muito pouco trabalho de detalhe havia sido feito para justificar uma condenação tão radical das bacias. No entanto, observando-se as avaliações das bacias feitas pelos dois grupos (Tab. 3), o de Link e o de Moura e Oddone (1962), apud Souza (1997), verifica-se haver poucas discrepâncias entre os dois.

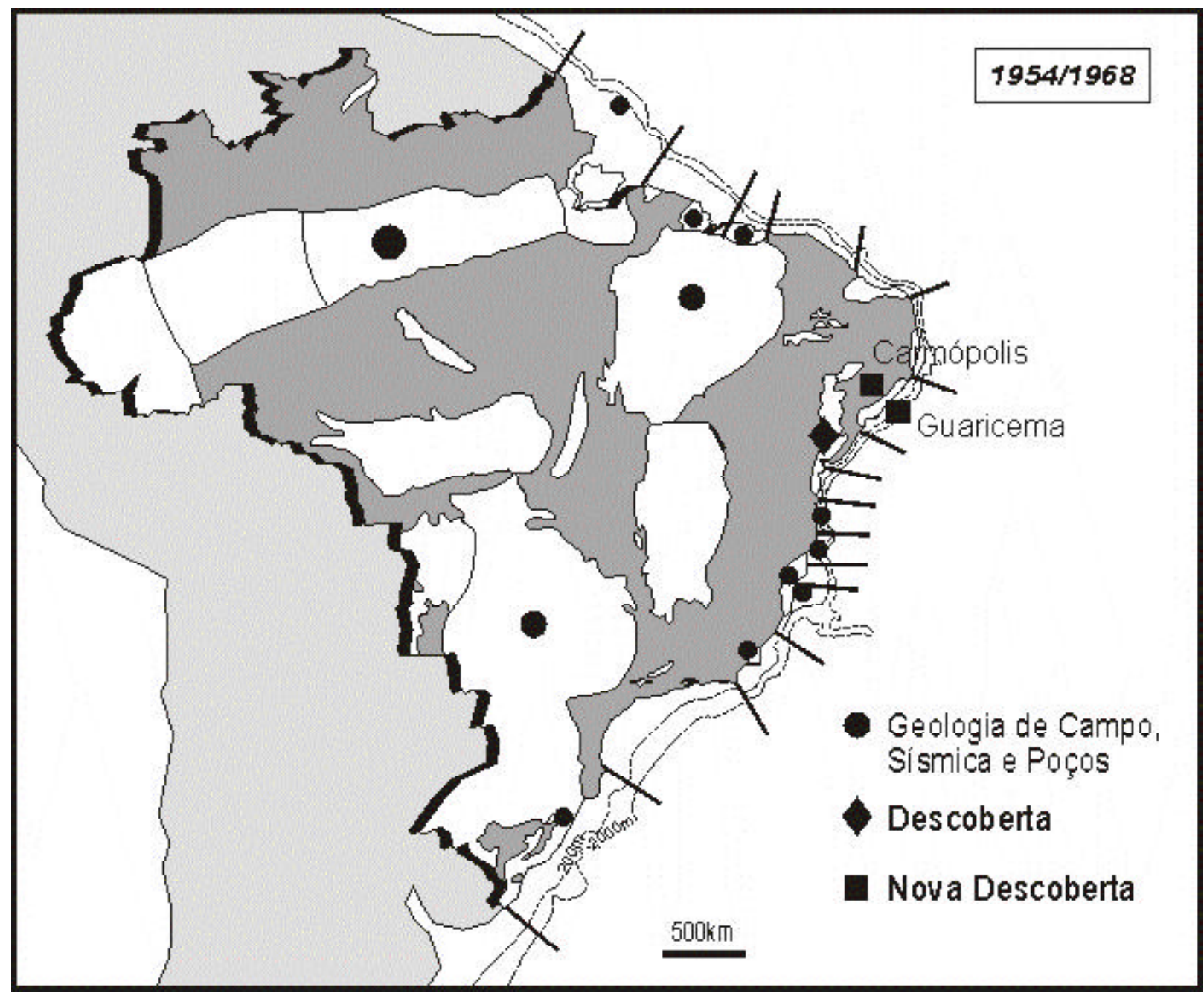

Figura 13 - Atividades exploratórias da Petrobras, Fase Terrestre. 
A maior divergência observada entre as duas classificações refere-se à Bacia de Barreirinhas, que passa de D+ (Link) para B (Moura \& Oddone), e no entanto, hoje, a bacia com cerca de 80 poços perfurados ainda não se caracterizou como produtora de petróleo. A Bacia de Sergipe-Alagoas, apesar de ter tido uma nota pessimista $(\mathrm{C}-)$ por parte da equipe de Link, nada indica que tivesse sido descartada se Link continuasse à frente da exploração. Link tinha comentários desfavoráveis principalmente contra a parte alagoana da bacia.

De qualquer maneira, parece que observadas com olhos de hoje, ambas as classificações padeceram da falta de dados, e principalmente, diante das expectativas criadas pelo ambiente de efervescência nacionalista que precederam a criação da Petrobras, pela ânsia (campanhas até certo ponto apressadas) em descobrir o petróleo em grandes quantidades que, esperava-se, moldaria o futuro da nação.

Sem dúvida, a passagem de Link pela Petrobras deixou um saldo extremamente positivo, no mínimo por ter criado a estrutura de organização da Petrobras, pela formação dos primeiros técnicos brasileiros e pela política inicial de treinamento da empresa, méritos que continuados pelas chefias brasileiras seguintes, permitiram à Companhia encontrar os caminhos até a posição de destaque que ela ocupa hoje. Hoje, com o conhecimento e resultados acumulados, sabemos que as avaliações feitas por Link e posteriormente por Moura e Oddone, refletem a própria Geografia do Petróleo, e comprovam que nem todas as bacias sedimentares congregam todas as condições para a acumulação de petróleo em grandes quantidades.

Apesar de um significativo aumento na produção (5 a 6 vezes), as reservas ao final da primeira metade deste período não cresceram na mesma proporção. Com a Petrobras já estabelecida e estruturada e o ciclo Link encerrado, a grande maioria dos técnicos era constituída de brasileiros. A atividade de perfuração de poços exploratórios aumentou significativamente, mas a atividade geofísica continuou nos mesmos níveis. Trabalhos de reconhecimento gravimétrico localizaram novas bacias cretácicas costeiras no norte (Bragança-Vizeu, São Luís, Barreirinhas e Pará-Maranhão) e no leste brasileiro (Jequitinhonha, Nativo no Sul da Bahia e Espírito Santo). Diminuíram as atividades nas bacias amazônicas e em outras bacias paleozóicas, transferindo-se os esforços para as bacias cretácicas costeiras, especialmente do Recôncavo, Tucano, Sergipe-Alagoas e Barreirinhas. A Petrobras estava na dependência total da produção dos campos de petróleo baianos.

Em 1963, foi descoberto em Sergipe-Alagoas o Campo de Carmópolis, que se tornaria a maior acumulação terrestre brasileira, um gigante, contrariando parcialmente o Relatório Link, divulgado dois anos antes. No final de 1967, com a idéia já amadurecida de explorar a Plataforma Continental, foi realizado extenso levantamento gravimétrico marítimo entre Cabo Frio e Recife. Em 1967/68, executou-se o reconhecimento com sísmica de reflexão de cobertura múltipla e registro digital de várias bacias da Plataforma Continental. Em 1968, duas equipes sísmicas terrestres da Petrobras foram implantadas e foi instalado o primeiro Centro de Processamento de Dados Sísmicos da empresa. Decorrentes dos levantamentos sísmicos anteriores, as primeiras sondas marítimas foram contratadas para perfurar os 2 primeiros poços no mar. No segundo deles foi descoberto o Campo de Guaricema, o primeiro campo de petróleo na Plataforma Continental brasileira. Ao final da fase, a maioria dos técnicos já era de brasileiros e iniciou-se a contratação regular de geólogos formados nos cursos recém criados nas universidades brasileiras.

Nesta primeira fase de monopólio da Petrobras, foram pesquisadas, de alguma forma, praticamente todas as bacias terrestres conhecidas, inclusive o Pantanal e as porções terrestres das bacias da Bahia Sul, Pelotas e Campos. A geologia de superfície, muito utilizada no início do período, foi perdendo terreno para os métodos potenciais (gravimetria e magnetometria) e principalmente para a sísmica de reflexão, já utilizada rotineira e intensivamente ao final do período. Sondas mais modernas e com maior capacidade foram compradas ou alugadas e poços mais profundos começaram a ser perfurados. Os registros dão conta de que foram perfurados nesta fase 1.120 poços em terra e os dois primeiros poços exploratórios no mar, na plataforma continental do Espírito Santo e de Sergipe-Alagoas, além de extensivos levantamentos geofísicos (Fig. 13). 


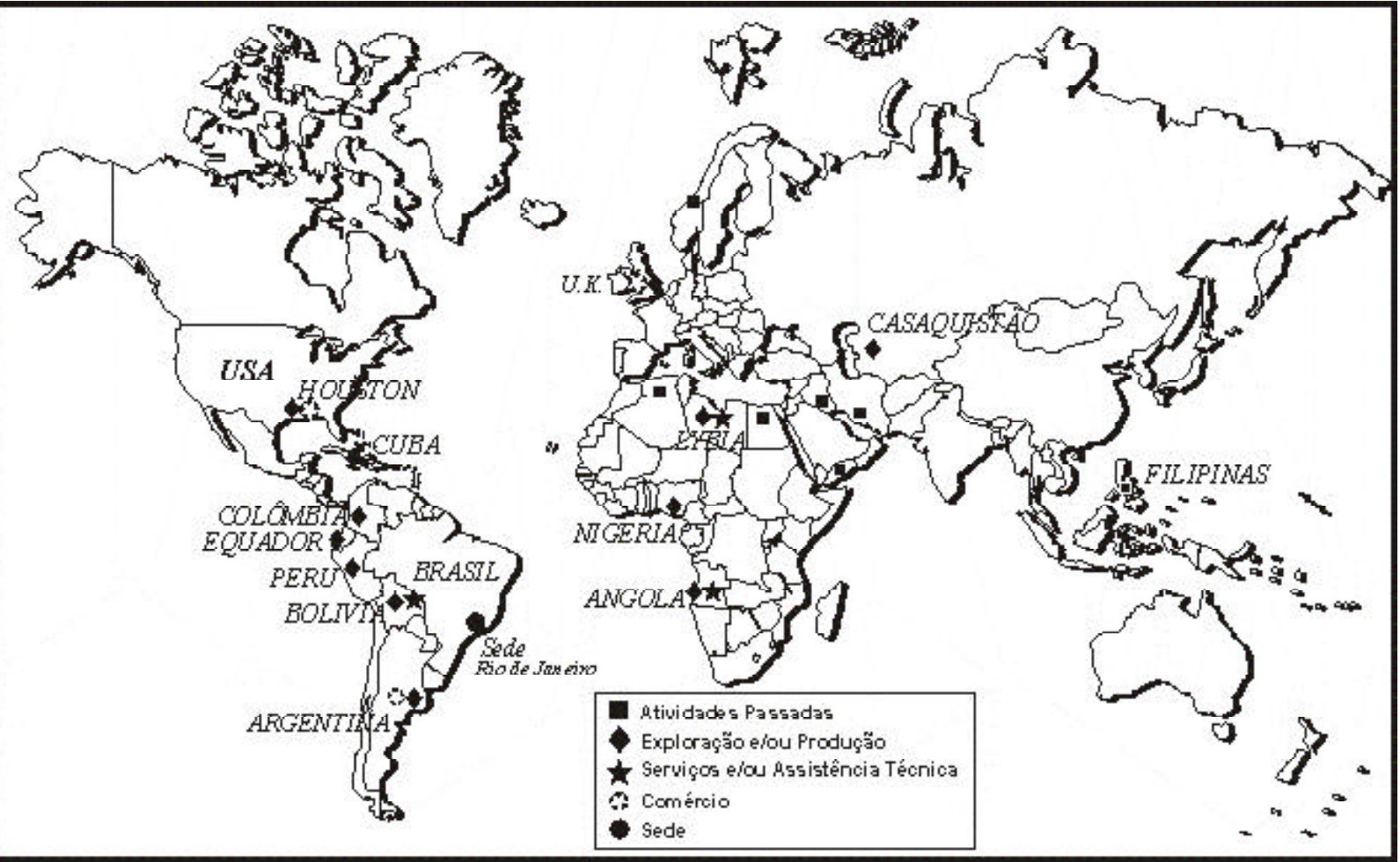

Figura 14 - Atividades da Braspetro no mundo.

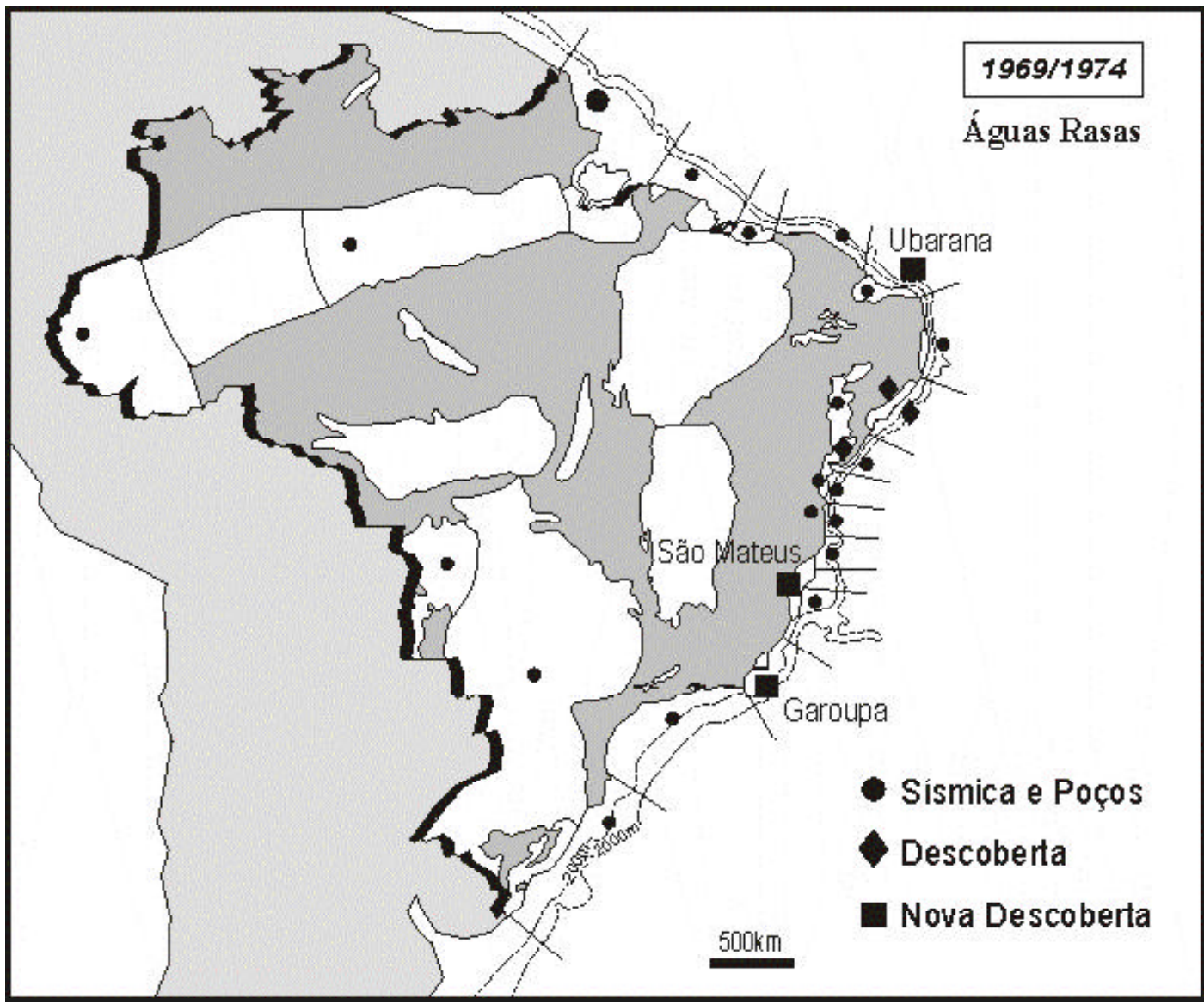

Figura 15 - Atividades exploratórias da Petrobras, Fase Marítima, 1969/1974. 
Os resultados desta fase foram 58 acumulações de óleo e gás descobertas, inclusive a primeira na plataforma continental (Guaricema, em SergipeAlagoas). Ao final de 1968, as reservas eram de 1,247 bilhões de barris e a produção brasileira de petróleo alcançava 163.884 barris por dia. A dependência externa continuava. Porém, com a descoberta de Guaricema na plataforma continental de Sergipe-Alagoas, renovaram-se as perspectivas de auto-suficiência, com o foco deslocado agora para o mar.

- 1969/1974: Fase Marítima/Plataforma Rasa

O Campo de Guaricema, descoberto com a perfuração do segundo poço marítimo, marcou o inicio desta fase. Esta descoberta, realizada na plataforma continental de Sergipe-Alagoas, renovou as perspectivas de auto-suficiência, deslocadas agora para o mar (Fig. 10). A ida para a Plataforma Continental baseava-se nos critérios de continuidade das bacias terrestres costeiras, com seus resultados e indícios e na analogia com outras bacias produtoras no mundo. Estudos da época estimavam em 20 bilhões de barris as reservas de petróleo da plataforma. Os grandes deltas da margem continental brasileira, como os da Foz do Amazonas, São Francisco, Rio Doce, Paraíba do Sul e Rio Grande, geraram grandes expectativas, especialmente pela influência dos consultores americanos e pela analogia com os deltas do Níger e do Mississipi. O Delta do Níger, no outro lado do Atlântico, já contava naquela

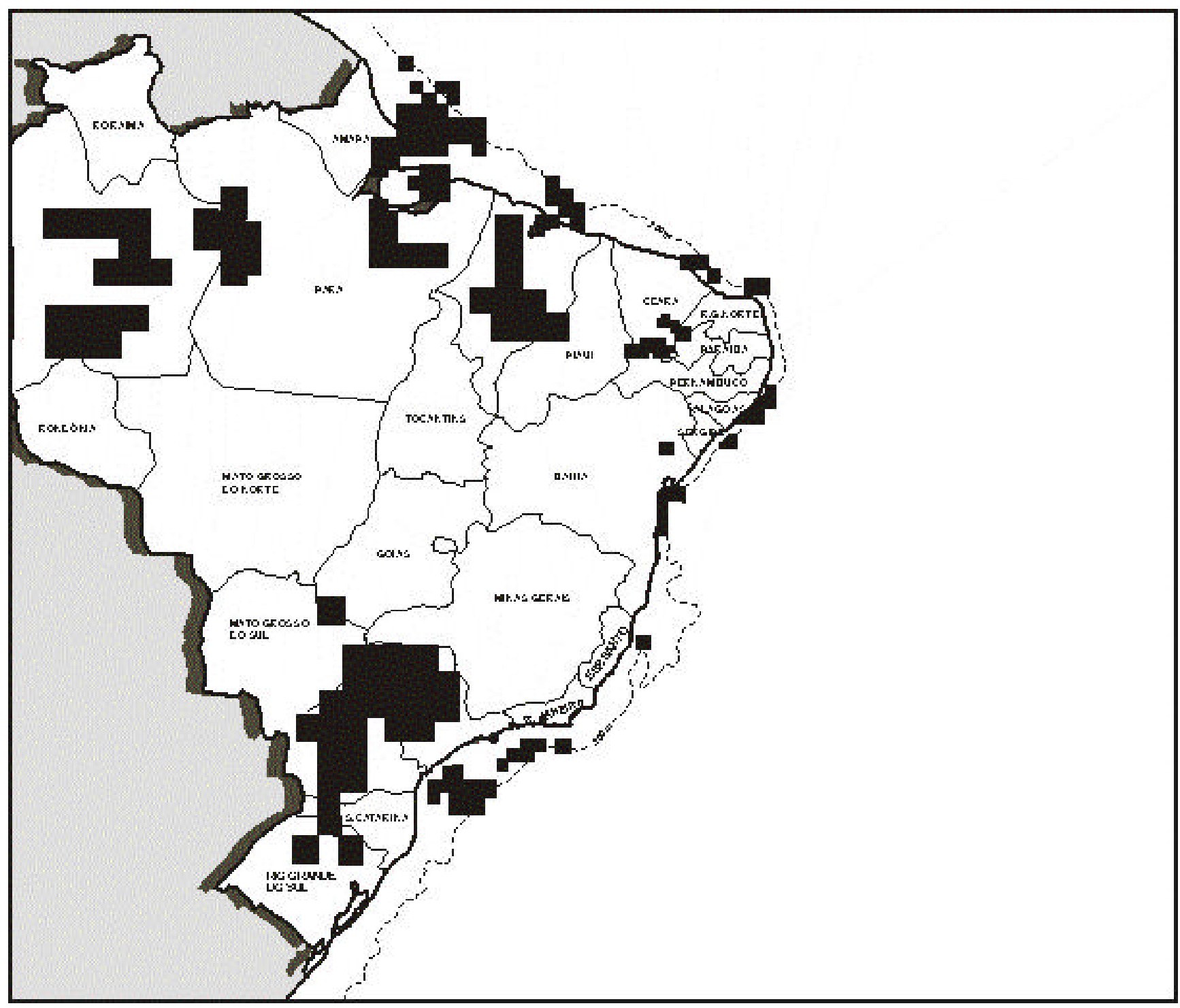

Figura 16 - Áreas de concessão aos Contratos de Risco. 
época com mais de 20 bilhões de barris de petróleo de reservas. $\mathrm{O}$ critério da continuidade respondeu discretamente, porém o da analogia fracassou e os poços secos se sucederam na Foz do Amazonas, Espírito Santo e Santos.

A descoberta, em 1969, do Campo de São Mateus, revelou o potencial da província terrestre do Espírito Santo. Em 1972, os distritos exploratórios foram esvaziados e as atividades em terra e o número de técnicos reduzidos. Os resultados modestos na plataforma marítima, aliados às reservas em declínio, levaram a companhia a duas importantes decisões: 1) a criação da Braspetro (Fig. 14), na tentativa de buscar no exterior o petróleo não encontrado internamente; 2) o direcionamento dos investimentos para o downstream (refino, transporte, petroquímica, comercialização). Com o Primeiro Choque do Petróleo, em 1973, e a descoberta do Campo de Ubarana na porção marítima da Bacia Potiguar, os investimentos no mar se elevaram novamente e, no apagar do ano de 1974, finalmente a primeira descoberta importante aconteceu no mar: o Campo de Garoupa, na Bacia de Campos (Fig. 15). Esta descoberta marcou o início de um novo ciclo no Brasil, renovando as esperanças, até então sempre frustradas, de auto-suficiência. Nesta fase, também, foi conferida ênfase especial ao treinamento dos técnicos brasileiros e à contratação sistemática de consultores estrangeiros alinhados com as mais recentes metodologias e tecnologias de E\&P. Nesta fase já reina, absoluta, a sísmica de reflexão como principal método investigativo em franca evolução tecnológica. Métodos potenciais são bastante utilizados, porém a Geologia de Superfície, pelas circunstâncias da exploração offshore, praticamente já não é mais utilizada.

Nesta fase, foram perfurados 316 poços exploratórios em terra e 165 na plataforma continental. Ao final desta fase, existiam cerca de 272 geólogos e geofísicos de petróleo no Brasil. Os resultados da fase foram 30 acumulações de óleo e gás descobertas, 20 em terra e 10 no mar, das quais as mais importantes em terra foram as de São Mateus e Fazenda Cedro, no Espírito Santo e Remanso no Recôncavo, e as do mar foram Ubarana, na Bacia Potiguar, e destacadamente Garoupa, na Bacia de Campos. No final de 1974 as reservas estavam em 1,445 bilhões de barris e a produção estava em 182.064 barris por dia.

- 1975/1984: Fase Marítima/Plataforma Rasa/Bacia de Campos

Em 1975 foi descoberto na Bacia de Campos o Campo de Namorado, o primeiro gigante da Plataforma Continental brasileira (Fig. 10). Os Contratos de Risco, decretados em 1976 (Fig. 16), permitiram a presença das empresas estrangeiras, como a Shell, Exxon, Texaco, BP, ELF, Total, Marathon, Conoco, Hispanoil, Pecten, Pennzoil e companhias brasileiras, como a Paulipetro, Azevedo Travassos, Camargo Correa, além da Petrobras, atuando no cenário da indústria petrolífera no Brasil.

Nesse período foi também descoberto o campo de gás do Juruá, na Bacia do Solimões (1978) e a primeira acumulação terrestre da Bacia Potiguar (1979). No mar, aconteceu a primeira descoberta por uma empresa sob contrato de risco, o campo de gás de Merluza, pela Pecten, na Bacia de Santos. Datam também desta época a criação do Proalcool, em 1980, numa tentativa nacional de reduzir a dependência externa de combustível, e o estabelecimento da meta do Governo Federal para a produção de 500.000 barris por dia em 1985. Em 1984, foram descobertos na Bacia de Campos o Campo de Marimbá e o gigante Albacora, ambos já indicando o irreversível caminho das águas profundas. A meta dos 500.000 barris por dia foi atingida ao final do ano de 1984, com antecipação de quase um ano. Esta fase teve início com as bacias cretácicas terrestres em natural declínio exploratório e a Bacia de Campos como nova esperança.

As importações de petróleo a US\$15/barril pesavam cada vez mais na balança comercial brasileira e, assim, com a necessidade de maior produção interna, tem inicio o desafio da engenharia de produção com os sistemas antecipados. A pressão da balança comercial resultou também na criação dos contratos de risco e o Segundo Choque do Petróleo agravou ainda mais a situação de dependência do petróleo estrangeiro. O treinamento dos técnicos da Petrobras foi acelerado, tanto no Brasil quanto no exterior. Foi a "Era Carlos Walter" na Petrobras. 


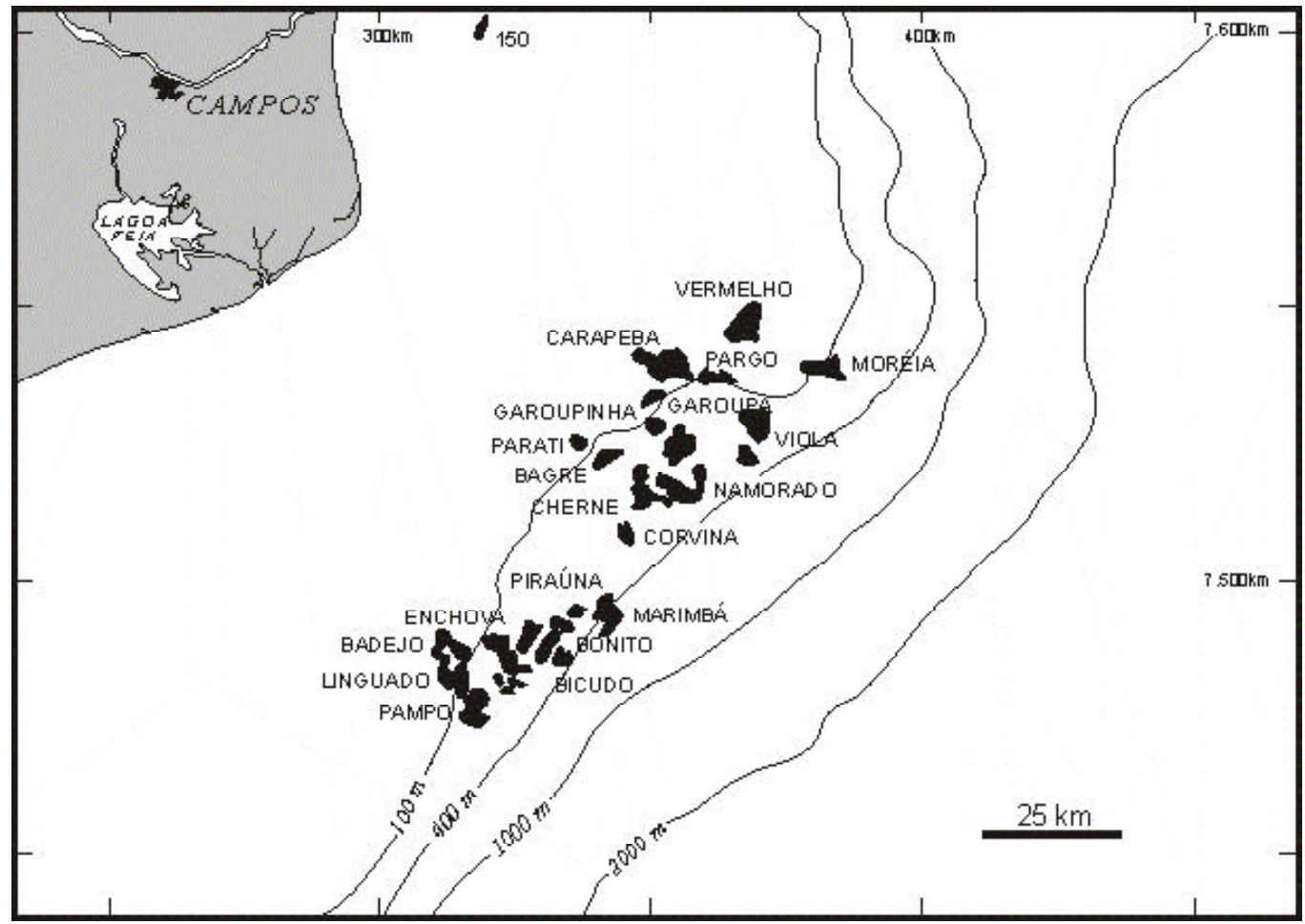

Figura 17 - Bacia de Campos, descobertas até 1984 - águas rasas.

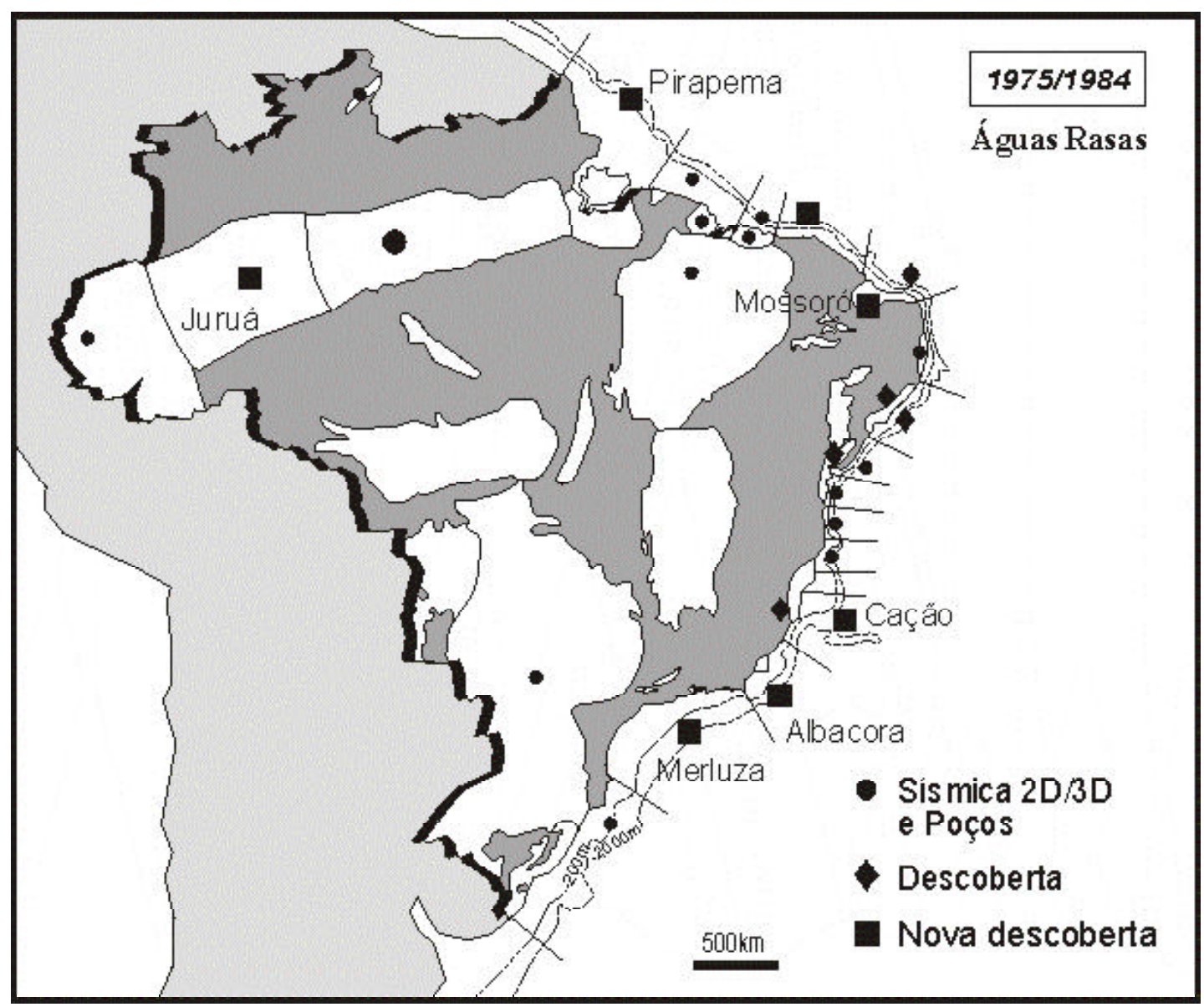

Figura 18 - Atividades exploratórias da Petrobras, Fase Marítima, 1975/1984. 


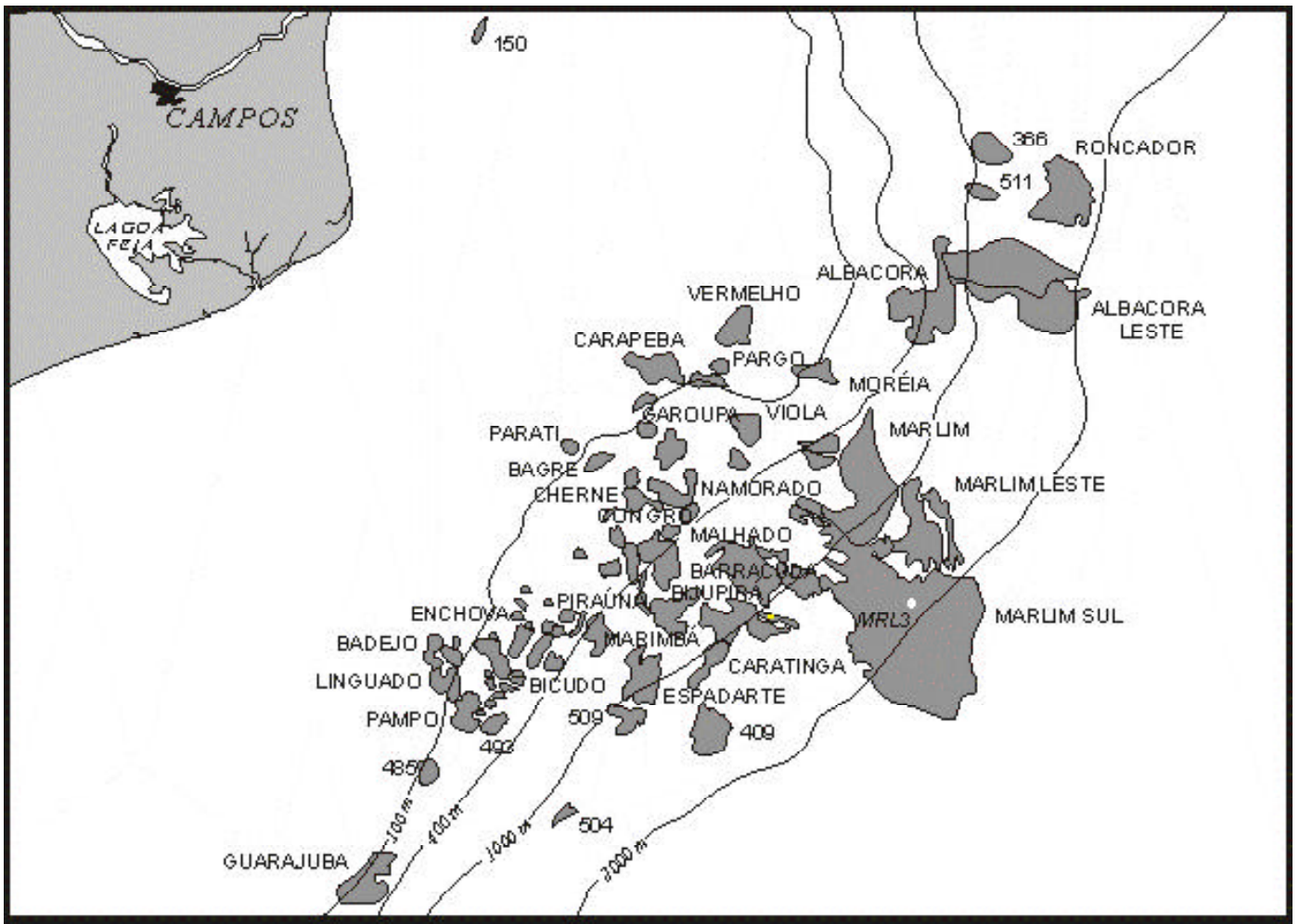

Figura 19 - Bacia de Campos, descobertas até 1997.

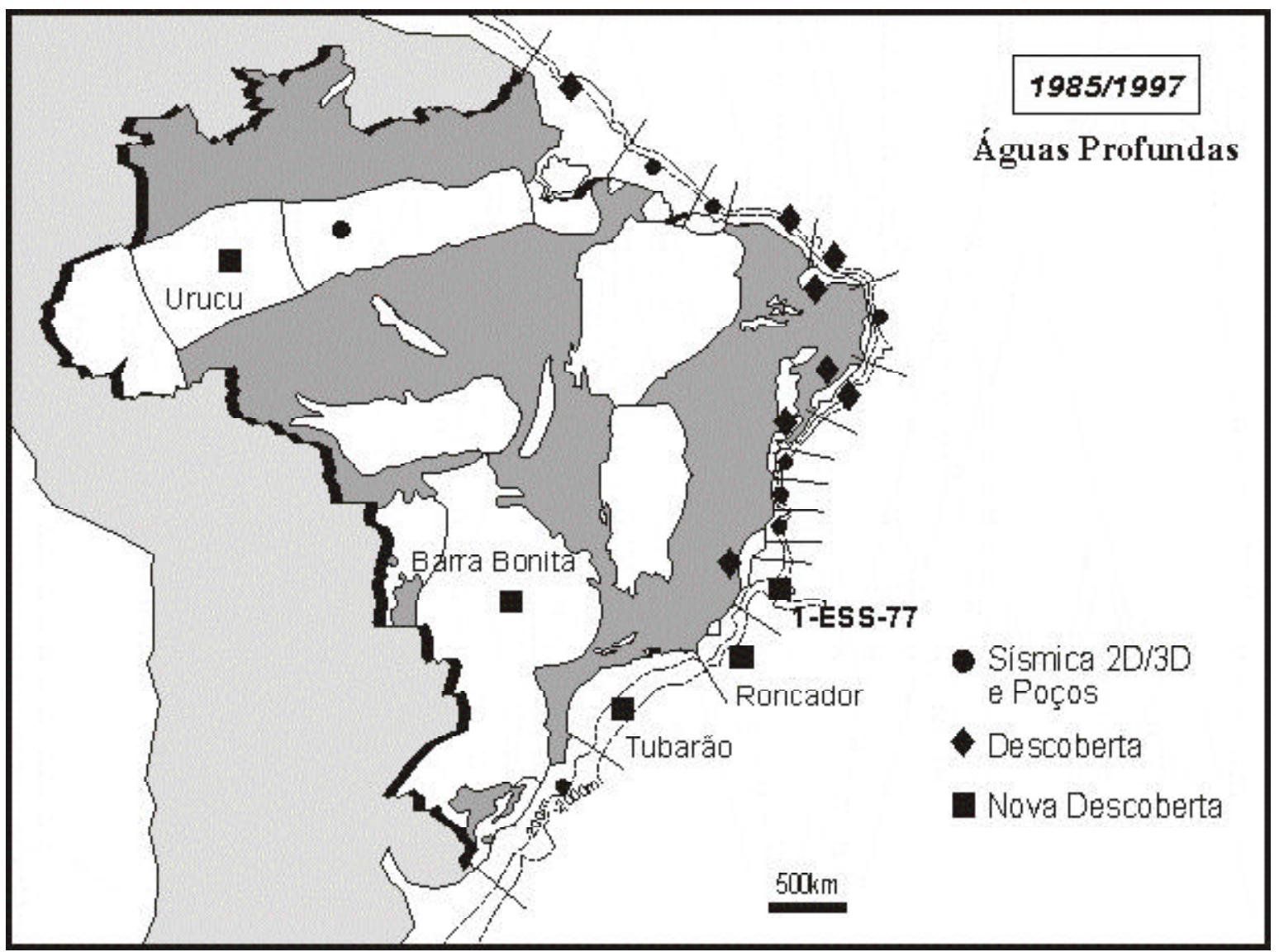

Figura 20 - Atividades exploratórias da Petrobras, Fase Marítima, 1985/1997. 
Carlos Walter Marinho Campos, falecido em 2000, foi o Gerente de Exploração da Petrobras que, em seu momento histórico, fomentou as atividades na plataforma continental, particularmente rumo às águas profundas da Bacia de Campos, ao mesmo tempo em que mantinha uma posição veementemente crítica à exploração nas bacias paleozóicas, por ele classificadas como "vendedoras de ilusões". Em parte, os resultados da exploração no Brasil têm corroborado o pensar de Carlos Walter, muito embora expressivas reservas de hidrocarbonetos tenham sido descobertas na Bacia do Solimões, a bacia paleozóica brasileira mais conhecida e amostrada.

A Bacia de Campos se afirmou com as novas descobertas e o desafio da engenharia foi vencido com os sistemas antecipados de produção (Fig. 17). A qualidade dos dados sísmicos melhorou consideravelmente e se anteciparam soluções para a produção em lâminas d'água maiores. O Centro de Processamento de Dados Sísmicos da Petrobras se tornou plenamente operante, oferecendo opções e soluções caseiras que facilitaram o trabalho dos exploracionistas. O Segundo Choque do Petróleo fez com que jazidas em águas mais profundas e as marginais em terra se tornassem economicamente viáveis. Assim, aconteceram os recordes de investimentos, resultando em mais descobertas e acréscimo substancial das reservas e da produção. O Pólo Nordeste da Bacia de Campos e a faixa de 400 m (Marimbá) de lâmina d'água contribuíram com importantes descobertas. A Bacia Potiguar terrestre se revelou com o trend Estreito-Guamaré e o Recôncavo se revitalizou a partir da descoberta de Riacho da Barra. Em 1985, navios de posicionamento dinâmico permitiram a perfuração em cotas batimétricas cada vez maiores, e logo nos primeiros poços foram descobertos os gigantes Albacora (400 a 1.000 metros) e Marlim (700 a 1.200 metros), com os turbiditos se afirmando como os principais reservatórios das bacias da Plataforma Continental brasileira. Com a acelerada informatização da Petrobrás, ganhou força a idéia de fortalecer o processamento sísmico interno, inclusive com a compra de supercomputadores. Os primeiros levantamentos de sísmica 3D revolucionaram e aceleraram a exploração no mar e navios de posicionamento dinâmico facilitaram o avanço para as águas profundas.

Nesta fase, foram perfurados pela Petrobras 885 poços em terra e 750 no mar. Enquanto isso, as empresas sob contrato de risco perfuraram 51 poços em terra e 64 no mar.

Como resultado, foram descobertas 148 acumulações de óleo e gás, 98 em terra e 50 no mar. As mais importantes em terra foram as de Juruá, no Solimões, Fazenda Belém e Alto do Rodrigues, na Bacia Potiguar, Riacho da Barra, no Recôncavo, e Pilar, em Sergipe-Alagoas. As mais importantes no mar foram Namorado, Enchova, Carapeba, Marimbá e Albacora, na Bacia de Campos (Fig. 18). Ao final de 1984, as reservas totais brasileiras alcançavam 4,29 bilhões de barris e a produção chegava a 488.400 barris por dia.

- 1985/1997: Fase Marítima/Bacia de Campos/ Águas Profundas

Confirmada a vocação da Bacia de Campos, outras descobertas importantes foram realizadas nas suas águas profundas. A sísmica 3D se afirmou como ferramenta, otimizando tempo e custos desde a descoberta até o desenvolvimento dos campos. A Petrobras começou a preparar o desenvolvimento de sistemas de produção em águas profundas. Levantamentos de sísmica 3D terrestre tornaram-se rotineiros e importantes descobertas de gás, óleo e condensado ocorreram na região do Rio Urucu e de óleo em carbonatos albianos da Bacia de Santos (Tubarão, Coral e Estrela do Mar). A exploração na Bacia de Campos foi caracterizada pelo aumento substancial da aquisição sísmica 3D, com a utilização de navios de fontes e cabos múltiplos que, conjuntamente com a interpretação sísmica interativa, otimizou a delimitação dos campos descobertos e os estudos de reservatório.

Os contratos de risco terminaram em 05/10/1988, permanecendo apenas os contratos de descobertas consideradas comerciais. Os levantamentos de sísmica 3D terrestres começaram a mostrar resultados, principalmente nas bacias do Espírito Santo, Potiguar e no Recôncavo, ao mesmo tempo em que outras importantes descobertas ocorriam na área de Rio 
Urucú (gás, condensado e óleo). Em Campos, o aumento substancial das campanhas de sísmica 3D, para guiar a exploração em áreas virgens, abriu novas frentes exploratórias e reduziu ainda mais os custos das descobertas e de delimitação na Bacia de Campos. A migração pré-empilhamento em profundidade, o processamento orientado para os objetivos, o posicionamento GPS e o processamento a bordo, foram outras novidades deste período, além da descoberta da primeira acumulação de gás na Bacia do Paraná, em Barra Bonita, e da última grande descoberta em águas profundas da Bacia de Campos, o Campo de Roncador, um gigante com óleo de boa qualidade, até agora o maior campo brasileiro (Fig. 19). Em 1997 foram iniciadas negociações de parceria com empresas multinacionais e brasileiras, nas áreas de exploração e desenvolvimento da produção, e em 06/08/1997 foi promulgada a lei 9.478/97, regulando a indústria do petróleo no Brasil, quebrando o monopólio da União representado até então pela Petrobras.

Em síntese, a quarta fase deste período teve como características a confirmação do potencial das águas profundas da Bacia de Campos, a afirmação da sísmica 3D como ferramenta exploratória das mais importantes e o cumprimento da meta de 1.000.000 de barris diários de produção. Na quarta e última fase foram perfurados pela Petrobras 930 poços em terra e 549 no mar. Por sua vez, as companhias sob contrato de risco perfuraram 71 poços em terra e 10 no mar. Os resultados da fase foram as 211 acumulações de óleo e gás descobertas, das quais 123 em terra e 88 no mar. No final de 1997 as reservas totais alcançavam 16,9 bilhões de barris e a produção diária era de 1.069 .000 barris. O ciclo de exclusividade da Petrobras na execução do monopólio da União na área petrolífera se encerraria com a promulgação da lei 9.478/97, dando início à "fase ANP”.

\section{Nova Lei Do Petróleo (9478/1997) - ANP/Águas Ultraprofundas}

Em novembro do ano de 1995, em notável contraste ao que ocorrera durante a nacionalista campanha popular “O Petróleo é nosso", que culminou no Monopólio do Petróleo pela União e na criação da Petrobras, após intensa campanha do Governo
Federal aliado aos meios empresariais e com o maciço apoio da mídia, o Congresso Nacional aprovou a Emenda Constitucional $\mathrm{n}^{\mathrm{o}}$ 9, com o propósito governamental de atrair investimentos estrangeiros através da abertura do Setor Petróleo Brasileiro. Como meio para atingir tal objetivo, foi aprovada a quebra do Monopólio que a Petrobras exercia em nome da União e, ao mesmo tempo foi possibilitado à Companhia estabelecer parcerias empresariais com investidores privados nacionais ou multinacionais, para a exploração, desenvolvimento da produção e produção de petróleo.

Quando, em seis de agosto de 1997, foi promulgada a Nova Lei do Petróleo (9478/97), regulamentando o Setor Petróleo Brasileiro e criando a Agência Nacional do Petróleo (ANP), oficializouse o início de uma nova era na Indústria do Petróleo Nacional, e finalmente, em seis de agosto de 1998, quando a Petrobras passou à condição de concessionária da ANP, concretizou-se a quebra do monopólio do petróleo. A partir da aprovação da Emenda Constitucional $\mathrm{n}^{\circ}$ 9, a Petrobras, devidamente autorizada pelo Ministério de Minas e Energia (MME), iniciou em maio de 1996, a demarcação das áreas exploratórias e dos campos de petróleo para requisição à Agência Nacional do Petróleo (ANP), e iniciou ainda contatos com empresas nacionais e estrangeiras visando a consecução de parcerias em algumas destas áreas e campos selecionados.

A partir destes contatos iniciais, em janeiro de 1997 foram assinados Memorandos de Entendimento com 151 companhias nacionais e estrangeiras. Em seguida, em maio do mesmo ano, estas empresas assinaram Termos de Confidencialidade para ter acesso e analisar os dados disponíveis acerca das áreas selecionadas para parceria. Esta nova era para a indústria do petróleo no Brasil foi oficializada em seis de agosto de 1997, quando foi promulgada e iniciou sua vigência a Lei 9478/97, denominada de "Nova Lei do Petróleo", que regulamentou o Setor e criou a Agência Nacional do Petróleo (ANP), para gerir e fiscalizar as atividades da área. A Agência Nacional do Petróleo foi implantada em janeiro de 1998, com sede operacional no Rio de Janeiro. A nova legislação estabeleceu para a Petrobras uma fase de transição de três anos para a conclusão de projetos exploratórios que estavam em andamento. Também 
para as recentes descobertas que ainda não estavam em efetiva produção, a lei deu um prazo de 3 anos para o início da produção comercial.

Assim, em atendimento aos novos requisitos legais, a Petrobras em outubro de 1997 requisitou oficialmente ao Ministério de Minas e Energia (MME), as áreas exploratórias que estavam com investimentos em andamento e os campos de petróleo descobertos até então. Foram solicitadas à ANP 133 áreas de exploração abrangendo cerca de 663.000 $\mathrm{km} 2$, aproximadamente $10 \%$ do total da área sedimentar brasileira. A recém-criada Agência contratou a Universidade Federal da Bahia (UFBA) para fazer a análise técnica das solicitações da Petrobras quanto às áreas Exploratórias e a Universidade de Campinas (UNICAMP), para analisar as áreas de Desenvolvimento da Produção e Produção requisitadas. Entre outubro de 1997 e março de 1998, a Companhia começou a receber propostas concretas de parceria em Exploração e Produção. As propostas foram analisadas e iniciouse a definição de operadores e associações, assim como as negociações dos termos comerciais dos projetos de parceria.

Finalmente, em junho de 1998, a ANP definiu as áreas que ficariam com a Petrobras, e em 6 de agosto de 1998 foram assinados entre a Companhia e a ANP os contratos de concessão de 115 blocos exploratórios englobando uma área total de cerca de $457.000 \mathrm{~km} 2$, aproximadamente $7 \%$ do total sedimentar brasileiro. Com a definição das áreas exploratórias e das condições contratuais, iniciou-se uma fase de ajuste das condições comerciais nos contratos de parceria em andamento, e os primeiros quatro contratos de parceria em exploração e três em desenvolvimento da produção foram assinados ainda naquele ano com as companhias estrangeiras YPF (depois Repsol-YPF), Santa Fé (depois DevonSta.Fé), Norbay, Coastal (depois El Paso-Coastal), Perez Companc, Union Pacific Resources (depois Anadarko-UPR), TDC, e com as nacionais Petroserv, Sotep e Ipiranga.

Em maio de 1999, a Companhia obteve da ANP a possibilidade de prorrogação, mediante descoberta, por dois anos do prazo de concessão para 34 blocos e por seis anos para outros 2 blocos, sendo a maioria destes blocos de águas profundas ou de fronteira exploratória. Na mesma ocasião, a Petrobras devolveu integralmente à ANP 26 blocos exploratórios e parte de outros dois. Em 1999, até junho, foram assinados mais cinco contratos exploratórios de parceria com as companhias estrangeiras Amerada Hess, British Borneo (depois Agip-British Borneo), Sipetrol, Tecpetrol e Santa Fé (depois Devon-Sta. Fé), e com a nacional Odebrecht.

Adicionalmente, em junho, a Petrobras obteve na Primeira Rodada de Licitações de Blocos Exploratórios promovida pela ANP, uma concessão de forma exclusiva e quatro outras em consórcio com as companhias Repsol-YPF, Agip-British Borneo, Amerada Hess, KerrMcGee, British Petroleum, EssoMobil e Shell. Outras sete concessões foram adquiridas pelas empresas Texaco, Agip, Esso-Mobil, Unocal e Repsol-YPF, exclusivamente e em parcerias, configurando aí a concretização da quebra do monopólio do petróleo no Brasil. Nesta Primeira Rodada foram ofertados pela ANP 26 blocos exploratórios.

Até o final de 1999, a Petrobras firmou mais 10 contratos de parceria nas suas áreas originais de exploração, com as estrangeiras Esso-Mobil, British Gás, Texaco, Nissho-Iwai, KerrMcGee, Unocal, Shell, Japex-Marubeni, Repsol-YPF, BP, TotalFinaElf e Enterprise, e com a empresa nacional Odebrecht. Ao final do ano de 1999, a Petrobras detinha direitos exclusivos ou em parceria em 94 concessões exploratórias e outras sete concessões exploratórias foram adquiridas por outras empresas, totalizando 101 concessões exploratórias em território brasileiro. Em janeiro de 2000, a Petrobras devolveu à ANP três blocos exploratórios e até junho do mesmo ano firmou mais seis parcerias em concessões exploratórias, com as empresas estrangeiras Chevron, ElPaso-Coastal, Enterprise e Amerada Hess, e com as nacionais Odebrecht, Queiroz Galvão e Petroserv.

Na Segunda Rodada de Licitações de Blocos Exploratórios da ANP realizada em junho de 2000, a Petrobras adquiriu direitos exclusivos sobre dois blocos e em parceria com as empresas Chevron, Shell, Petrogal, British Gas, Repsol-YPF e Amerada Hess, sobre outros seis blocos. Outras 13 concessões foram adquiridas pelas empresas estrangeiras Coastal, PanCanadian, Santa Fé, SK, Shell, Rainier, Amerada Hess e Union Pacific, e as nacionais Odebrecht, 
Queiroz Galvão e Ipiranga. Ao todo foram ofertadas 23 áreas e adquiridas 21. Desta forma, ao final de 2000, a Petrobras detinha direitos sobre 99 blocos exploratórios, e outras companhias eram concessionárias de outros 20 blocos exploratórios, totalizando 119 concessões exploratórias no Brasil.

Em junho de 2001 foi realizada a Terceira Rodada de Licitações de Blocos Exploratórios promovida pela ANP, com oferta de 53 áreas exploratórias em diversas bacias sedimentares brasileiras. A Petrobras fez propostas em 20 blocos, tendo adquirido direitos em 15 deles, sete com exclusividade, e oito em consórcio com as empresas Enterprise, Statoil, Queiroz Galvão, Petroserv, ElPaso, Esso-Mobil, KerrMcGee, Petrogal, TotalFinaElf e Shell. Outras 15 empresas adquiriram mais 18 áreas exploratórias, totalizando 33 novas concessões adquiridas. Em julho de 2001 existiam 114 concessões exploratórias onde a Petrobras tinha participação exclusiva ou em parcerias e outras 38 concessões de outras empresas, totalizando 152 em toda a área sedimentar brasileira.

Em seis de agosto do mesmo ano, tendo expirado o prazo da Fase de Exploração (3 anos) de 50 blocos não prorrogáveis e de outros oito prorrogáveis porém sem descoberta, a Petrobras retornou à Agência Nacional do Petróleo (ANP) um total de 58 blocos exploratórios. Nos 50 blocos não prorrogáveis foram retidas apenas as áreas que delimitam as descobertas de hidrocarbonetos notificadas e cujos planos de avaliação foram apresentados pelos concessionários à ANP, para avaliação técnica e comercial das jazidas encontradas.

Após seis de agosto de 2001, existiam 94 concessões exploratórias ativas nas bacias sedimentares brasileiras, 56 da Petrobras e 38 de outras empresas, e mais 270 concessões de desenvolvimento da produção (41) e produção (229) da Petrobras, exclusivamente ou em parceria. Este período atual da Exploração teve como características além do novo cenário já implantado, com a realização de três licitações promovidas pela ANP e a presença no Brasil de cerca de $40 \%$ de todos os navios de aquisição sísmica existentes no mundo, a utilização da sísmica 3D com finalidade exploratória nas bacias terrestres, com excepcionais resultados nas bacias do Espírito Santo e Potiguar. Na Plataforma Continental, intensificou-se a exploração em águas profundas fora da Bacia de Campos, principalmente nas bacias de Santos e Espírito Santo. Além disso, iniciou-se em 1999 a exploração na região de águas ultraprofundas, com a perfuração dos primeiros poços em cotas batimétricas maiores que 2.000 metros, tendo ocorrido uma primeira descoberta modesta, no norte da Bacia de Campos, no ano de 2000.

\section{Síntese dos resultados da Exploração}

As acumulações descobertas, conseqüência do esforço exploratório acima descrito, foram 10 até 1953, 447 entre 1954 e 1997, e outras 45 no período de 1998 a agosto de 2001. As reservas brasileiras de petróleo estão hoje assim distribuídas: provadas de óleo $=7,1$ bilhões de barris, e de gás $=228$ bilhões de $\mathrm{m} 3$, com totais em 16,1 bilhões de barris de óleoequivalente. A produção acumulada, ao final de 2000 , era de 6,8 bilhões de barris de óleo-equivalente, que somados às reservas totais remanescentes, dão um total de 23 bilhões de óleo-equivalente como recursos descobertos pela atividade exploratória no Brasil até os dias de hoje.

\section{A exploração de petróleo na margem continental brasileira: aspectos ambientais}

Os oceanos constituem uma vasta fronteira fluida, dinâmica, multiestratificada e complexa como nossa atmosfera, porém muito mais desconhecida pelos homens. As superficies sem água de Marte, Vênus e da Lua já foram mapeadas, em contraste com apenas 5\% do assoalho de nossos mares. Entretanto, algumas das decisões ambientais e econômicas mais importantes a respeito do aquecimento global, a descoberta de novas fontes de energia, a predição de variações climáticas, a pesca sustentável e a proteção da propriedade costeira dependem do conhecimento e entendimento dos nossos oceanos.

Nosso entendimento a respeito do funcionamento dos oceanos tem mudado também. Tomemos por exemplo a relação dos oceanos com a questão da energia e do aquecimento global. Foram descobertas recentemente pistas de que o gás natural metano pode estar percolando para cima do assoalho oceânico em 
grandes quantidades. Isto poderia ser uma grande fonte potencial de energia. O metano é também um importante agente ambiental, se ele sobe para a superfície do mar, gradualmente ou em pulsos súbitos, pode ter um papel importante na questão do aquecimento global. Por outro lado, é também possível que os oceanos ajudem a mitigar o aquecimento global pela absorção de grandes quantidades de dióxido de carbono, outro agente ambiental da atmosfera.

Aproximadamente dez anos após as primeiras descobertas nas regiões da plataforma continental, a Petrobras descobriu o seu primeiro campo gigante na região do talude continental, em lâmina d'água maior de 700 metros, abrindo desta forma uma nova fronteira exploratória e um novo patamar tecnológico de produção de hidrocarbonetos. A produção destes campos é um processo dispendioso e que requer uma tecnologia específica e precisa devido aos riscos ambientais envolvidos. Entretanto, os volumes de óleo encontrados nos campos de água profunda justificam o desenvolvimento desta nova tecnologia de produção e hoje a Petrobras tem completado rotineiramente poços em lâminas d'água profundas, com poços produtores situados em lâminas d'água maiores que $1.870 \mathrm{~m}$ e poços exploratórios situados em profundidades próximas de 2.800 metros. A produção destes campos requer também um bom conhecimento das condições ambientais e de estabilidade do subsolo marinho, onde se assentarão todos os equipamentos de extração de petróleo. Condições de mar, força e direção das ondas e correntes também devem ser precisamente conhecidas, bem como a circulação submarina, para que operações seguras de produção possam ser executadas.

A extensão ou continuidade do território brasileiro em direção ao Oceano Atlântico foi delimitada com acurácia através de um grande projeto conduzido pela Marinha do Brasil e pela Petrobras, segundo os critérios estabelecidos pela Convenção das Nações Unidas sobre o Direito do Mar. O Plano de Levantamento de Plataforma Continental Brasileira (Projeto LEPLAC) objetiva estabelecer a área oceânica além do limite marítimo das 200 milhas da Zona Econômica Exclusiva (ZEE) brasileira, na qual, segundo os termos da convenção, o Brasil exercerá direitos exclusivos de soberania para a exploração e o aproveitamento de recursos naturais do leito marinho e do subsolo desta área.

Por ser o petróleo um recurso estratégico, o conhecimento do potencial petrolífero do território brasileiro deve ser buscado em seu maior grau de precisão possível. Este conhecimento depende tanto de investimentos nas áreas de tecnologia, quanto na formação de pessoal e, principalmente de investimentos de alto risco em área pouco exploradas. A Petrobras ao longo de sua existência, sempre primou por acompanhar e desenvolver tecnologia específica na área do petróleo e na formação de pessoal capacitado a executar seus trabalhos, bem como, por ampliar a exploração às áreas de fronteira, como atestado por seus resultados em águas profundas. No novo cenário imposto pela nova lei do petróleo, cabe à agência controladora (ANP) estimular investimentos nas áreas acima mencionadas.

As margens continentais correspondem à transição entre a crosta continental e a oceânica. São regiões onde espessos pacotes sedimentares podem ser encontrados, e como o petróleo é gerado e acumulado nestas rochas, as margens possuem grande potencial petrolífero. A soberania nesta região é importante para o Brasil e o critério estabelecido pelas Nações Unidas leva em consideração a espessura sedimentar existente na sua extremidade mais afastada do território emerso. A espessura sedimentar é obtida através de levantamentos sísmicos. A Petrobras e a Marinha do Brasil executaram um extenso trabalho, com o Projeto LEPLAC, visando ao Brasil exercer sua hegemonia na exploração e aproveitamento dos recursos naturais do leito marítimo e do subsolo ao longo de seu extenso território submerso.

A exploração e a produção de petróleo são atividades que requerem extremo cuidado em relação à preservação ambiental. A Petrobras, através de seus diversos órgãos operacionais e de seu centro de pesquisas, desenvolveu procedimentos e tecnologias para evitar, detectar e minimizar danos ao meio ambiente causados por acidentes em suas operações. Os derrames devem ser evitados ao máximo e, quando ocorrem, suas origens e responsabilidades devem ser apuradas como medida de prevenção futura. 


\section{CONSIDERAÇÕES FINAIS}

Da análise da história da exploração de petróleo no Brasil e os resultados alcançados pode-se concluir que há ainda inúmeros desafios para os atores envolvidos nesta importante atividade econômica. Para a ANP, o grande desafio será o de promover e incentivar a ocupação com atividades de exploração em todas as bacias sedimentares brasileiras. A atividade, que envolve grande risco e substantiva exposição financeira, é fortemente impactada pela oferta e demanda internacional de óleo. Com a recente abertura à exploração pela maioria dos países onde existe potencial petrolífero, a competição para atração de investimentos de risco é extremamente elevada. $\mathrm{O}$ enorme conhecimento adquirido principalmente nas ultimas quatro décadas, pelo esforço da Petrobras, dos contratos de risco e das comunidades acadêmicocientíficas do país, vai contribuir para que o órgão regulador promova a adequada gestão de exploração de petróleo no Brasil.

As bacias sedimentares brasileiras têm grande diversidade geológica e, como conseqüência, riscos exploratórios diferenciados. O potencial petrolífero remanescente das bacias brasileiras e a nova legislação vigente podem criar as condições para atrair investimentos brasileiros e internacionais. Um regime fiscal adequado ao risco das bacias brasileiras e as condições contratuais das concessões são condições básicas para o crescimento dos recursos petrolíferos brasileiros. O porte do mercado consumidor brasileiro, em expansão, constitui-se também em grande atrativo a investimentos em exploração e produção no país.

As perspectivas futuras sinalizam, sem dúvida, para um cenário exploratório onde as parcerias e as futuras licitações deverão tornar o ambiente exploratório mais ágil e competitivo, com trocas de experiência, conhecimento e tecnologia entre as empresas participantes, processo este que, se adequadamente gerenciado, trará um efetivo ganho para o País sob a perspectiva do fornecimento energético.

\section{REFERÊNCIAS}

ALBERTÃO, G.A., 1995. Abordagem interdisciplinar e epistemológica sobre as evidências do limite Cretáceo-Terciário, com base em leituras efetuadas no registro sedimentar das bacias da costa leste brasileira. Boletim de Geociências da Petrobras 9(2/4), 321-322.

ALMEIDA, F.F.M. \& CARNEIRO, C.D.R., 1998. Origem e evolução da Serra do Mar. Revista Brasileira de Geociências 28(2), 135-150.

ALMEIDA, F.F.M \& HASUI, Y., 1984. O PréCambriano do Brasil. Edgard Blücher, São Paulo, Brasil.

ALMEIDA, F.F.M., HASUI, Y., NEVES, B.B.B., FUCK, R.A., 1977. Províncias estruturais brasileiras. Anais do I Simpósio de Geologia do Nordeste, pp. 363-391, Campina Grande, Brazil.

ARARIPE, P.T. \& FEIJÓ, F.J., 1994. Bacia Potiguar. Boletim de Geociências da Petrobras 8(1), 127-141.

ASMUS, H.E. (1984). Geologia da margem continental brasileira. In Geologia do Brasil, eds Schobbenhaus, C., Campos, D.A., Derze, G.R., and Asmus, H.E., pp. 443-472. Departamento Nacional da Produção Mineral, Brasília, Brasil.

ASMUS, H.E. \& PONTE, F.C., 1973. The Brazilian marginal basins. In The ocean basins and margins, eds Nairn, A.E.M. and Stehli, F.G., pp. 87-133. Plenum Press, New York, USA.

AZEVEDO, R.P., 1991. Tectonic evolution of Brazilian equatorial margin basins. Tese de doutorado, University of London, Imperial College, $455 \mathrm{pp}$.

BACOCCOLI, G., 1986. A exploração de petróleo no Brasil, ed. Petrobras/Depex, III Congresso Brasileiro de Petróleo, Rio de Janeiro, RJ, Brasil.

BACOCCOLI, G., COSTA I. G \& BRANDÃO, J.A.S.L., 1989. O processo da descoberta de bacias petrolíferas no Brasil, ed. Petrobras/Depex, I Seminário de Interpretação Exploratória, Rio de Janeiro, RJ, Brasil, p. 383/390.

BELTRAMI，C.V.; CALDEIRA，J.L.; FREITAS, R.W., 1989. Análise sismoestratigráfica dos sedimentos oligo-miocênicos da Bacia do Ceará - Águas profundas. I SINTEX, pp. 185-194.

BELTRAMI, C.V., ALVES, L.E.M.\& FEIJÓ, F.J., 1994. Bacia do Ceará. Boletim de Geociências da Petrobras 8(1), 117-125.

BERTANI, R.T., COSTA, I.G.\& MATOS, R.M.D., 1990. Evolução tectono-sedimentar, estilo estrutural e hábitat do petróleo da Bacia Potiguar. In 
Origem e evolução de bacias sedimentares, eds Raja Gabaglia, G.P and Milani, E.J., pp. 291-310. Petrobras, Rio de Janeiro, Brasil.

BRANDÃO, J.A.S., 1990. Revisão e atualização estratigráfica das bacias da Foz do Amazonas e ParáMaranhão, Petrobras (Rel. Int.), 79 pp.

BRANDÃO, J.A.S.L. \& FEIJÓ, F.J., 1994a. Bacia da Foz do Amazonas. Boletim de Geociências da Petrobras 8(1), 91-99.

BRANDÃO, J.A.S.L. \& FEIJÓ, F.J., $1994 b$. Bacia do Pará-Maranhão. Boletim de Geociências da Petrobras 8(1), 101-102.

CAINELLI, C. \& MOHRIAK, W.U., 1998. Brazilian Geology part II: Geology of Atlantic Eastern Brazilian basins. Rio'98 AAPG International Conference and Exhibition, American Association of Petroleum Geologists/Associação Brasileira de Geólogos de Petróleo, Short Course Notes, Rio de Janeiro, Brasil.

CAIXETA, J.M., BUENO, G.V., MAGNAVITA, L.P.\& FEIJÓ, F.J., 1994. Bacias do Recôncavo, Tucano e Jatobá. Boletim de Geociências da Petrobras 8(1), 163-172.

CASTRO, A.S., 1992. Arcabouço estrutural e evolução tectônica da sub-bacia de Icaraí, Bacia do Ceará. Dissertação de mestrado, UFOP, 107 pp.

CASTRO JR., A.C.M., 1994. Aspectos estruturais das bacias de Barreirinhas e do Ceará. II SINTEX, pp.278-281.

CHANG, H.K., KOWSMANN, R.O., FIGUEIREDO, A.M.F.\& BENDER, A.A., 1992. Tectonics and stratigraphy of the East Brazil rift system (EBRIS): an overview. Tectonophysics 213, 97-138. CONCEIÇÃO, J.C.J., ZALÁN, P.V.\& WOLFF, S., 1988. Mecanismo, evolução e cronologia do rifte Sul Atlântico. Boletim de Geociências da Petrobras 2(2/4), 255-265.

COSTA, I.G., BELTRAMI, C.V.\& ALVES, L.E.M., 1989. A evolução tectono-sedimentar e o "habitat do óleo da Bacia do Ceará. I SINTEX, pp. 75-85.

CREMONINI, O.A., GOULART, J.P.M.\& SOARES, U.M., 1998. Tectonic-stratigraphic evolution of offshore Potiguar Basin, Brazil. Proceedings of the Rio'98 AAPG International Conference and Exhibition, pp. 44-45, Rio de Janeiro, Brazil.
DEMERCIAN， S., SZATMARI，P.\& COBBOLD, P.R., 1993. Style and pattern of salt diapirs due to thin-skinned gravitational gliding, Campos and Santos basins, offshore Brazil. Tectonophysics 228, 393-433.

DIAS, J.L., 1991. Análise estratigráfica e e evolução da fase rift nas bacias das margens leste e sudeste do Brasil. Dissertação de mestrado, UFRJ, 145 pp.

DIAS, J.L., 1998. Análise sedimentológica e estratigráfica do Andar Aptiano em parte da margem leste do Brasil e no platô das Malvinas considerações sobre as primeiras incursões marinhas do oceano Atlântico Sul meridional. Universidade Federal do Rio Grande do Sul, unp. $\mathrm{PhD}$ thesis, Porto Alegre, Brasil.

DIAS, J.L., SAD, A.R.E., FONTANA, R.L.\& FEIJÓ, F.J., 1994. Bacia de Pelotas. Boletim de Geociências da Petrobras 8(1), 235-245.

DIAS, J.L., SCARTON, J.C., ESTEVES, F.R., CARMINATTI, M. \& GUARDADO, L.R., 1990. Aspectos da evolução tectono-sedimentar e a ocorrência de hidrocarbonetos na Bacia de Campos. In Origem e evolução de bacias sedimentares, eds Raja Gabaglia, G.P and Milani, E.J., pp. 333-360. Petrobras, Rio de Janeiro, Brasil.

DIAS, J.L.M.\& QUAGLINO, M. A., 1993. A questão do petróleo no Brasil, uma história da Petrobras, CPDOC/SERINST, Fundação Getúlio Vargas Petrobras, 213p.

FEIJÓ, F.J., 1994a. Bacia de Barreirinhas. Boletim de Geociências da Petrobras 8(1): 103-109.

FEIJÓ, F.J., 1994b. Bacia de Pernambuco-Paraíba. Boletim de Geociências da Petrobras 8(1): 143147.

FEIJÓ, F.J., 1994c. Bacias de Sergipe e Alagoas. Boletim de Geociências da Petrobras 8(1): 149161.

FONTANA, R.L., 1989. Evidências geofísicas da presença de hidratos de gás na Bacia de Pelotas. In Anais do Primeiro Congresso Brasileiro de Geofisica 1, pp. 234-248. Sociedade Brasileira de Geofísica, Rio de Janeiro, Brasil.

FONTANA, R.L., 1990. Desenvolvimento termomecânico da Bacia de Pelotas e parte sul da Plataforma de Florianópolis. In Origem e evolução de bacias sedimentares, eds Raja Gabaglia, G.P and 
Milani, E.J., pp. 377-400. Petrobras, Rio de Janeiro, Brasil.

GORINI, M.A., 1977. The tectonic fabric of the Equatorial Atlantic and adjoining continental margins: Gulf of Guinea to northeastern Brazil. Columbia University, unp. PhD thesis, Columbia, USA.

GRADSTEIN, F. \& OGG, J., 1996. A Phanerozoic time scale. Supplement to Episodes 19(1-2).

GUARDADO, L.R., GAMBOA, L.A.P.\& LUCCHESI, C.F., 1990. Petroleum geology of the Campos Basin, Brazil, a model for a producing Atlantic type basin. In: Edwards, J.D and Santogrissi, P.A., divergent/Passive Margin Basins. Tulsa, AAPG Memoir 48, pp. 3-79.

GUIMARÃES, P.T.M., MACHADO, E.R.; SILVA, S.R.P., 1989. Interpretação sismoestratigráfica em águas profundas na Bacia do Pará-Maranhão. I SINTEX, pp.171-183.

LANA, M. C. \& MILANI, E. J., 1986. A microplaca do Nordeste brasileiro - um elemento dinâmico no rifteamento cretácico inferior. In Anais do XXXIV Congresso Brasileiro de Geologia 3, pp. 1131-1144. Sociedade Brasileira de Geologia, Goiânia, Brasil.

LELARGE, M.L.M.V., 1993. Thermochronologie par la methode des traces de fission d'une marge passive (dome de Ponta Grossa, SE Brésil) et au sein d'une chaine de collision (zone externe de lárc Alpin, France). Universite Joseph Fourier, unp. PhD thesis, Grenoble, France.

MAGOON, L. B., \& DOW, W. G., 1994. The Petroleum System, in Magoon, L. B., and Dow, W. G., eds., The petroleum system - From source to trap: American Association of Petroleum Geologists Memoir 60, p. 3-24.

MANSPEIZER, W., 1988. Triassic-Jurassic rifting and opening of the Atlantic: an overview. In TriassicJurassic rifting, ed Manspeizer, W., pp. 41-79. Elsevier, Developments in Geotectonics 22, Amsterdam, the Netherlands.

MATOS, R.M.D., 1998. The transversal zone: a key feature between NE Brazil and W Africa. Proceedings of the Rio'98 AAPG International Conference and Exhibition, pp. 426-427, Rio de Janeiro, Brazil.
MATOS, R.M.D., 2000. Tectonic evolution of the Equatorial South Atlantic. In Atlantic rifts and continental margins, eds. Mohriak, W.U. and Talwani, M., pp. 331-354. American Geophysical Union, Geophysical Monograph 115, Washington, USA.

MATOS, R.M.D. \& WAICK, R.N., 1998. A unique transform margin: the Equatorial Atlantic. Proceedings of the Rio'98 AAPG International Conference and Exhibition, pp. 798-799, Rio de Janeiro, Brazil.

MILANI, E. J., 1985. Tectônica cisalhante na evolução do rift do Recôncavo-Tucano-Jatobá. Revista Brasileira de Geociências 15(4): 287-292. MILANI, E.J., 1987. Aspectos da evolução tectônica das Bacias do Recôncavo e Tucano Sul, Bahia, Brasil. Petrobras, Série Ciência-TécnicaPetróleo 18, Rio de Janeiro, Brasil.

MILANI, E.J., 1991. Anomalias gravimétricas em bacias do tipo rifte: exemplos brasileiros. Anais do II Congresso Internacional da Sociedade Brasileira de Geofísica 1, pp. 172-176, Salvador, Brasil.

MILANI, E.J. \& LATGÉ, M.A.L., 1987. Modelagem gravimétrica da porção terrestre da Bacia Potiguar e suas implicações geotectônicas. Boletim de Geociências da Petrobras 1(1): 75-85.

MILANI, E.J. \& SZATMARI, P., 1998. Rift dynamics in Northeastern Brazil. Proceedings of the Rio'98 AAPG International Conference and Exhibition, pp. 368-369, Rio de Janeiro, Brazil.

MILANI, E.J. \& THOMAZ FILHO, A., 2000. Sedimentary basins of South America. In: Cordani, U.G.; Milani, E.J.; Thomaz Filho, A.; and Campos, D.A. (Eds.), Tectonic evolution of South America. Rio de Janeiro, $31^{\text {st }}$ International Geological Congress, pp. 389-452.

MILANI, E.J. \& ZALÁN, P.V., 1998. Brazilian Geology Part 1: the Geology of Paleozoic Cratonic Basins and Mesozoic Interior Rifts of Brazil. Rio'98 AAPG International Conference and Exhibition, American Association of Petroleum Geologists/Associação Brasileira de Geólogos de Petróleo, Short Course Notes, Rio de Janeiro, Brasil. MILANI, E.J., LANA, M.C. \& SZATMARI, P., 1988. Mesozoic rift basins around the Northeast Brazilian microplate (Recôncavo-Tucano-Jatobá, Sergipe-Alagoas). In Triassic-Jurassic rifting, ed 
Manspeizer, W., pp. 833-858. Elsevier, Developments in Geotectonics 22, Amsterdam, the Netherlands.

MIURA, K. \& BARBOSA, J.C., 1972. Geologia da plataforma continental do Maranhão, Piauí, Ceará e Rio Grande do Norte. Anais do XXVI Congresso Brasileiro de Geologia 2, pp. 57-66, Belém, Brasil. MOHRIAK, W.U., MACEDO, J.M., CASTELLANI, R.T., RANGEL, H.D., BARROS, A.Z.N., LATGÉ, M.A.L., RIZZI, J.A., MIZUSAKI, A.M.P., SZATMARI, P., RIZZO, J.G. \& AIRES, J.R., 1995. Salt tectonics and structural styles in the deep-water province of the Cabo Frio region, Rio de Janeiro, Brazil. In Salt tectonics: a global perspective, eds. Jackson, M.P.A., Roberts, D.G., and Snelson, S., pp. 273304. American Association of Petroleum Geologists, Memoir 65, Tulsa, USA.

MOURA, P. DE, \& CARNEIRO, F. O., 1976. Em busca do petróleo brasileiro, ed Rio de Janeiro, edit. Fundação Gorceix, Ouro Preto, MG, 360p.

NETTO, A.S.T., FILHO, J.R.W. \& FEIJÓ, F.J., 1994. Bacias de Jacuípe, Camamu e Almada. Boletim de Geociências da Petrobras 8(1), 173-184.

OJEDA, H.A., 1982. Structural framework, stratigraphy and evolution of Brazilian marginal basins. American Association of Petroleum Geologists Bulletin 66, 732-749.

PEREIRA, M.J., 1994. Possíveis influências do tectono-magmatismo intraplaca na sedimentação do Cretáceo de cinco bacias marginais brasileiras. II SINTEX, pp.57-62.

PEREIRA, M.J. \& FEIJÓ, F.J., 1994. Bacia de Santos. Boletim de Geociências da Petrobras 8(1), 219-234.

RANGEL, H.D. \& E MARTINS, C. C., 1998. Principais Compartimentos Exploratórios, Bacia de Campos, Capítulo 2, Cenário Geológico nas Bacias Sedimentares no Brasil, Publicação Especial da Revista The Search, Searching for Oil and Gas in the Land of Giants, Schlumberger, Rio de Janeiro.

RANGEL, H.D., MARTINS, F.A.L., ESTEVES, F.R.\& FEIJÓ, F.J., 1994. Bacia de Campos. Boletim de Geociências da Petrobras 8(1), 203217.

SANTOS, J.E.M., SETI,C.J. \& RODRIGUES,M.V.G., 1994a. Panorama geral dos
Contratos de Risco, Relatório Interno, Petrobras/Depex/ Dicex, 137p

SANTOS, C.F., GONTIJO, R.C., ARAÚJO, M.B., FEIJÓ, F.J., 1994b. Bacias de Cumuruxatiba e Jequitinhonha. Boletim de Geociências da Petrobras 8(1), 185-190.

SILVA, S.R.P \& RODARTE, J.B.M., 1990. Bacia da Foz do Amazonas e Pará-Maranhão (Águas Profundas): uma análise sismoestratigráfica, tectonosedimentar e térmica. Petrobras (Rel. Int.).

SOUZA, R.G., 1997. Petróleo, Histórias das Descobertas e o Potencial Brasileiro, Niterói, ed. Muiraquitã, $272 \mathrm{p}$.

SZATMARI, P. \& MILANI, E.J., 1999. Microplate rotation in northeast Brazil during South Atlantic rifting: Analogies with the Sinai microplate. Geology 27(12): 1115-1118.

SZATMARI, P., MILANI, E.J., LANA, M.C., CONCEIÇÃO, J.C.J., LOBO, A.P., 1984. How South Atlantic rifting affects Brazilian oil reserves distribution. Oil and Gas Journal 83, 107-113.

SZATMARI，P., FRANÇOLIN，J.B.L., ZANOTTO, O.A. \& WOLFF, S., 1987. Evolução tectônica da margem equatorial brasileira. Revista Brasileira de Geociências 17, 180-188.

U.S.G.S. WORLD ENERGY ASSESSMENT TEAM (2000) U.S.G.S. WORLD PETROLEUM ASSESSMENT 2000. Description and Results, U.S.G.S. Digital Data Series DDS-60, Multi Disc Set (4 CD ROM's) Version 1.0, U.S.G.S., U.S. Department of the Interior

VIEIRA, R.A.B., MENDES, M.P., VIEIRA, P.E., COSTA, L.A.R., TAGLIARI, C.V., BACELAR, A.P.\& FEIJÓ, F.J., 1994. Bacias de Espírito Santo e Mucuri. Boletim de Geociências da Petrobras 8(1), 191-202.

ZALÁN, P.V., 1985. Tectonics and sedimentation of the Piauí-Camocin sub-basin, Ceará Basin, offshore northeastern Brazil. Petrobras, Série Ciência-TécnicaPetróleo 17, Rio de Janeiro, Brasil.

ZALÁN, P.V., 2001. Growth Folding in Gravitational Fold-and-Thrust Belts in the Deep Waters of the Equatorial Atlantic, Northeastern Brazil. AAPG Annual Convention Official Program Book and CDROM, Denver, June, p. A223. 


\section{NOTE ABOUT THE AUTHORS}

\section{Edison José Milani}

Formado em geologia pela UFRGS em 1977, tendo ingressado na Petrobras em 1978. Possui os títulos de Mestre em Geologia pela UFOP (1985) e Doutor em Ciências pela UFRGS em (1996). Dentro da Petrobras tem atuado principalmente na área de interpretação exploratória, tendo atuado como exploracionista nas bacias de Recôncavo, Tucano, Paraná, Santos e Marajó. $\mathrm{Na}$ área internacional realizou trabalhos nas bacias sub-andinas da Argentina e da Bolívia e em diversas bacias da África do Sul. Exerceu cargos de gerente de exploração das bacias offshore do norte do Brasil (1987-1988) e da Bacia do Paraná (1988-1994). Atualmente é gerente de tecnologias de análise de sistemas petrolíferos da Petrobras. Suas especializações são na área de estratigrafia, tectônica, análise de bacias e exploração petrolífera em bacias rifte, de margem passiva e intracratônicas. Adicionalmente, é instrutor eventual de cursos internos na Petrobras e em diversas universidades nacionais.

\section{José Augusto Sartori Loyola Brandão}

Graduou-se em Geologia pelo Instituto de Geosciências da Universidade Federal do Rio de Janeiro em 1972, tendo ingressado na PETROBRAS em 1973. Trabalhou inicialmente nos Distritos de Exploração do Norte, em Belém - PA, e de Exploração e Produção do Nordeste, em Aracajú - SE, até 1975, quando foi cedido para a BRASPETRO. Na BRASPETRO, braço internacional da PETROBRAS, trabalhou nas Filipinas, Argélia e Iraque, até 1979, quando retornou à Companhia. Participou do Curso de Atualização em Técnicas Exploratórias (CATEX) em 1980, tendo sido transferido para a sede da Empresa em 1981. Entre 1981 e 1996 trabalhou como geólogo na análise e interpretação de bacias da costa norte (Foz do Amazonas, Pará-Maranhão e Barreirinhas) e da costa sudeste (Bacia de Santos), tendo participado no período de diversos treinamentos técnicos e gerenciais e de missão pela BRASPETRO (1990) no Equador. Ocupou a função gerencial de Chefe de Setor de Interpretação das bacias da Costa Norte (SENORT). De 1997 a 2000 ocupou a função de Assistente Técnico (ASTEC) da Gerência de Exploração (GEREX) do Departamento de Exploração e Produção (E\&P) da PETROBRAS e desde o inicio de 2001 passou a desempenhar a função de Assistente da Gerência Executiva do E\&P.

\section{Pedro Victor Zalán}

Formado em geologia pela UFRJ em 1977, tendo ingressado na Petrobras em 1978. Possui os títulos de M.Sc. (1983) e Ph.D. (1984) em Geologia pela Colorado School of Mines, Golden, CO, USA. Toda a sua carreira tem se desenrolado dentro da Petrobras, tendo trabalhado por cinco anos na área internacional (Braspetro). Atualmente tem o cargo de Consultor Técnico, sendo especializado nas áreas de geologia estrutural/tectônica, análise de bacias sedimentares e exploração em águas profundas. Suas atividades exploratórias envolveram bacias sedimentares do mundo todo, desde o Proterozóico (Bacias do São Francisco e Parecis e Sibéria Oriental), passando pelo Paleozóico (bacias intracratônicas brasileiras e o sul do Mar do Norte), pelo Mesozóico (margens continentais brasileira, argentina e africana, margens colisionais no Acre, Oriente Médio e riftes no Yemen e Mar do Norte) até o Cenozóico (Golfo do México e Foz do Amazonas). Adicionalmente, é instrutor de cursos internos na Petrobras na área de estilos tectônicos e exploração em águas profundas.

\section{Luiz A. P. Gamboa}

Geólogo formado pela UFGJ, obteve o mestrado em geologia marinha na UFRGS e o doutorado na Universidade de Columbia, Nova Yorque,USA. Trabalhou na Gulf Oil , no Ocean Drilling Program e foi professor na Universidade de Texas A \& M, College Station, Texas. Trabalha do Departamento de Exploração e Produção da Petrobras e no Departamento de Geologia da Universidade Federal Fluminense. 